$$
\begin{aligned}
& \text { ARMY.CERC } \\
& \text { US Army Coast. Eug. Res Cf Tr. IP } \\
& \text { TP 78-4 }
\end{aligned}
$$

\title{
Geometry of Profiles Across Inner Continental Shelves of the Atlantic and Gulf Coasts of the United States
}

by

Craig H. Everts

\section{TECHNICAL PAPER NO. 78-4}

\section{APRIL 1978}
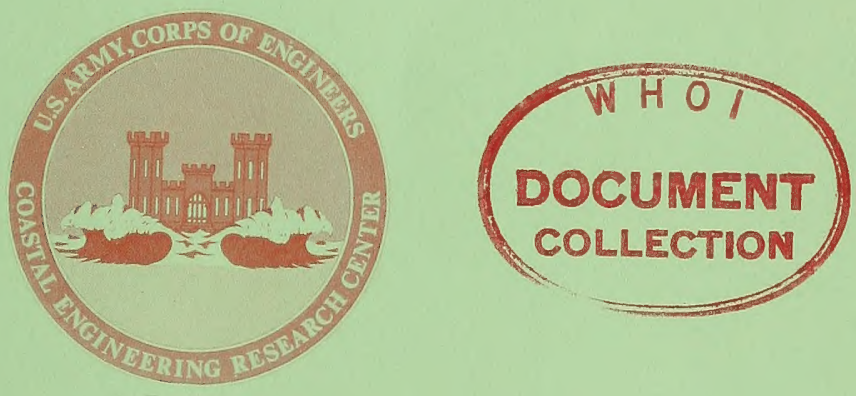

Approved for public release; distribution unlimited.

U.S. ARMY, CORPS OF ENGINEERS

COASTAL ENGINEERING

GB RESEARCH CENTER

450

Kingman Building

T4

Fort Belvoir, Va. 22060

$12.78-4$ 
Reprint or republication of any of this material shall give appropriate credit to the U.S. Army Coastal Engineering Research Center.

Limited free distribution within the United States of single copies of this publication has been made by this Center. Additional copies are available from:

\section{National Technical Information Service ATTN: Operations Division 5285 Port Royal Road Springfield, Virginia 22151}

The findings in this report are not to be construed as an official Department of the Army position unless so designated by other authorized documents. 


\section{REPORT DOCUMENTATION PAGE}

READ INSTRUCTIONS

1. REPORT NUMBER

TP $78-4$

4. TITLE (and Subtitle)

GEOMETRY OF PROFILES ACROSS INNER CONTINENTAL

SHELVES OF THE ATLANTIC AND GULF COASTS OF

THE UNITED STATES

7. $A U T H O R(s)$

BEFORE COMPLETING FORM

3. RECIPIENT'S CATALOG NUMBER

5. TYPE OF REPORT \& PERIOD COVERED

Technical Paper

6. PERFORMING ORG. REPORT NUMBER

8. CONTRACT OR GRANT NUMBER( 8 )

Craig H. Everts

9. PERFORMING ORGANIZATION NAME AND ADDRESS

Department of the Army

Coastal Engineering Research Center (CERRE-CP)

Kingman Building, Fort Belvoir, Virginia 22060

11. CONTROLLING OFFICE NAME AND ADDRESS

Department of the Army

Coastal Engineering Research Center

Kingman Building, Fort Belvoir, Virginia 22060

14. MONITORING AGENCY NAME \& ADDRESS(If different from Controlling Office)

10. PROGRAM ELEMENT, PROJECT, TASK AREA \& WORK UNIT NUMBERS

D31194

12. REPORT DATE

April 1978

13. NUMBER OF PAGES

92

15. SECURITY CLASS. (of this report)

UNCLASSIF IED

15a. DECLASSIFICATION/DOWNGRADING SCHEDULE

16. DISTRIBUTION STATEMENT (of this Report)

Approved for public release; distribution unlimited.

17. DISTRIBUTION STATEMENT (of the abstract entered in Block 20, if different from Report)

18. SUPPLEMENTARY NOTES

19. KEY WORDS (Continue on reverse side if necessary and identlfy by bluck number)

At lantic coast

Bathymetric profiles

Beach Evaluation Program
Gulf coast

Inner Continental Shelf

20. ABSTRACT (Coutinue an roveras side if neceseary and identify by block number)

Along most of the U.S. east and gulf coasts, bottom profiles extending over the Inner Continental Shelves normal from the coast display a characteristic two-sector shape. Near the coast, the shoreface profile sector is steep and concave-up; the seaward ramp sector is planar with a gradual slope away from the coast. As part of the Beach Evaluation Program (BEP) at the Coastal Engineering Research Center, 9 profiles extending from the coast $30.5 \mathrm{kilo-}$ meters (19 miles) seaward at each of 49 localities were averaged to

(Continued) 
mathematically characterize the profiles and to develop and test criteria for discriminating among groups of profiles. Localities were selected along straight coastal reaches away from inlets and estuaries in areas where the bottom consisted of unconsolidated sediments.

Results of the study indicate Inner Continental Shelf profiles can be mathematically defined by four parameters: $a$ = ramp slope ( 0 to 0.00107); $b=$ depth of the ramp at the shoreline, when the ramp is extended as a straight line below the shoreface sector ( 0 to 24.7 meters, 0 to 81 feet); $3 c=$ distance from the shoreline to the shoreface-ramp boundary $(0.2$ to 20.6 kilometers, 0.12 to 12.9 miles); and $f=$ index of concavity of the shoreface sector $(0.21$ to 1.72$)$. Values in parentheses are the range of values obtained for the 49 averaged profiles. All depths are referenced to mean low water. An cquation was developed to define bottom depth as a function of distance from shore incorporating the four relatively easy to obtain parameters. Computed depths using the equation were found to be generally within 5 percent of the actual profile depths at the 49 localities. In most cases, no relationship was found between the geometric characteristics of the shoreface and the ramp. 


\section{PREFACE}

This report is published to provide coastal engineers with representative bathymetric profiles of the Inner Continental Shelf along the Atlantic and gulf coasts of the United States. The work was carried out under the Beach Evaluation Program (BEP) of the U.S. Army Coastal Engineering Research Center (CERC).

The report was prepared by Dr. Craig H. Everts, under the supervision of Dr. C.J. Galvin, Jr., Chief, Coastal Processes Branch, Research Division.

The author acknowledges the assistance of W.N. Seelig and E. Adams who obtained most of the depth-distance values from charts. Mr. Seelig also assisted in computer programing. R.J. Hallermeier, C.J. Galvin, Jr. , and M.P. O'Brien reviewed the manuscript and provided many valuable suggestions for improvement.

Comments on this publication are invited.

Approved for publication in accordance with Public Law 166, 79th Congress, approved 31 July 1945, as supplemented by Public Law 172, 88th Congress, approved 7 November 1963.

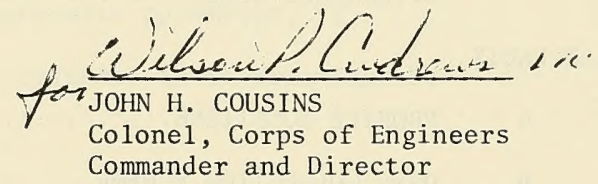




\section{CONTENTS}

Page

CONVERSION FACTORS, U.S. CUSTOMARY TO METRIC (SI) . . • . 6 SYMBOLS AND DEFINITIONS. . . . . . . . . . . . . 7

I INTRODUCTION . . . . . . . . . . . . . . . 9

I I BACKGROUND . . . . . . . . . . . . . . . . 9

II I MEASUREMENT PROCEDURE. . . . . . . . . . . . . . . 10

1. Inner Continental Shelf Profiles . . . . . . . 10

2. Shore-Parallel Contours. . . . . . . . 12

IV RESUlTS. . . . . . . . . . . . . . . . . 12

1. Shoreface Types. . . . . . . . . . . . 12

2. Description of Shelf Profiles. . . . . . . . 16

3. Limit Depth of Shore-Para11e1 Contours . . . . 18

$\mathrm{V} \quad$ DISCUSSION . . . . . . . . . . . . . . . 18

Profile Characteristics. . . . . . . . 18

VI GEOMETRIC LIMIT DEPTH OF THE SHOREFACE . . . . . . . . . 25

VII SUMMARY. . . . . . . . . . . . . . . . . 27

LITERATURE CITED . . . . . . . . . . . . . 29

APPENDIX

A PROFIlE LOCATIONS. . . . . . . . . . . . . . 31

B DATA COLLECTION SCHEME . . . . . . . . . . . . 35

C INNER CONTINENTAL SHELF PROFILES . . . . . . . . . . • 37

D PROFILE FITTING PROCEDURE. . . . . . . . . . . 87

E A PROGRAMING LANGUAGE (APL) PROGRAM TO FIT A CURVE TO A PROFILE. . . . . . . . . . . . . . . . 92

TABLES

1 Geometric characteristics of Inner Continental Shelf profiles for the U.S. Atlantic and Gulf of Mexico coasts. . . 19

2 Shoreface-ramp depths on Inner Continental Shelf profiles. . . 20 


\section{CONTENTS}

FJ GURLS

Page

1 Map showing the location of the 49 averaged bathymetric profiles obtained between Long Island and the Texas-

Mexico border. . . . . . . . . . . . . . . 1j

2 Profile line spacing and bathymetry at profile line $1 . . . .13$

3 l'rofile line 48 illustrating smooth, shore-parallel contours which exist beyond the seaward end of the profile. . . . . . 14

4 Examples of the three types of shoreface profiles . . . . . . 15

5 Definition sketch of an idealized Inner Continental Shelf profile showing the planar, seaward-dipping, ramp sector and the concave-up shoreface sector. . . . . . . . . . . 16

6 Rms depth variations along profiles . . . . . . . . . . . 21

7 Gulf of Mexico (Texas coast) profiles illustrating an increase in ramp slope, a, from northeast to southwest. . . . . . . 23

8 Atlantic coast (North and South Carolina) profiles illustrating a decreasing zero-intercept depth, b, from north to south. ................ . 23

9 Profiles illustrating the concavity parameter, f . . . . . . 24

10 Comparison of the geometric criteria in determining the seaward-limit depth. . . . . . . . . . . . . 26 
U.S. customary units of measurement used in this report can be converted to metric (SI) units as follows:

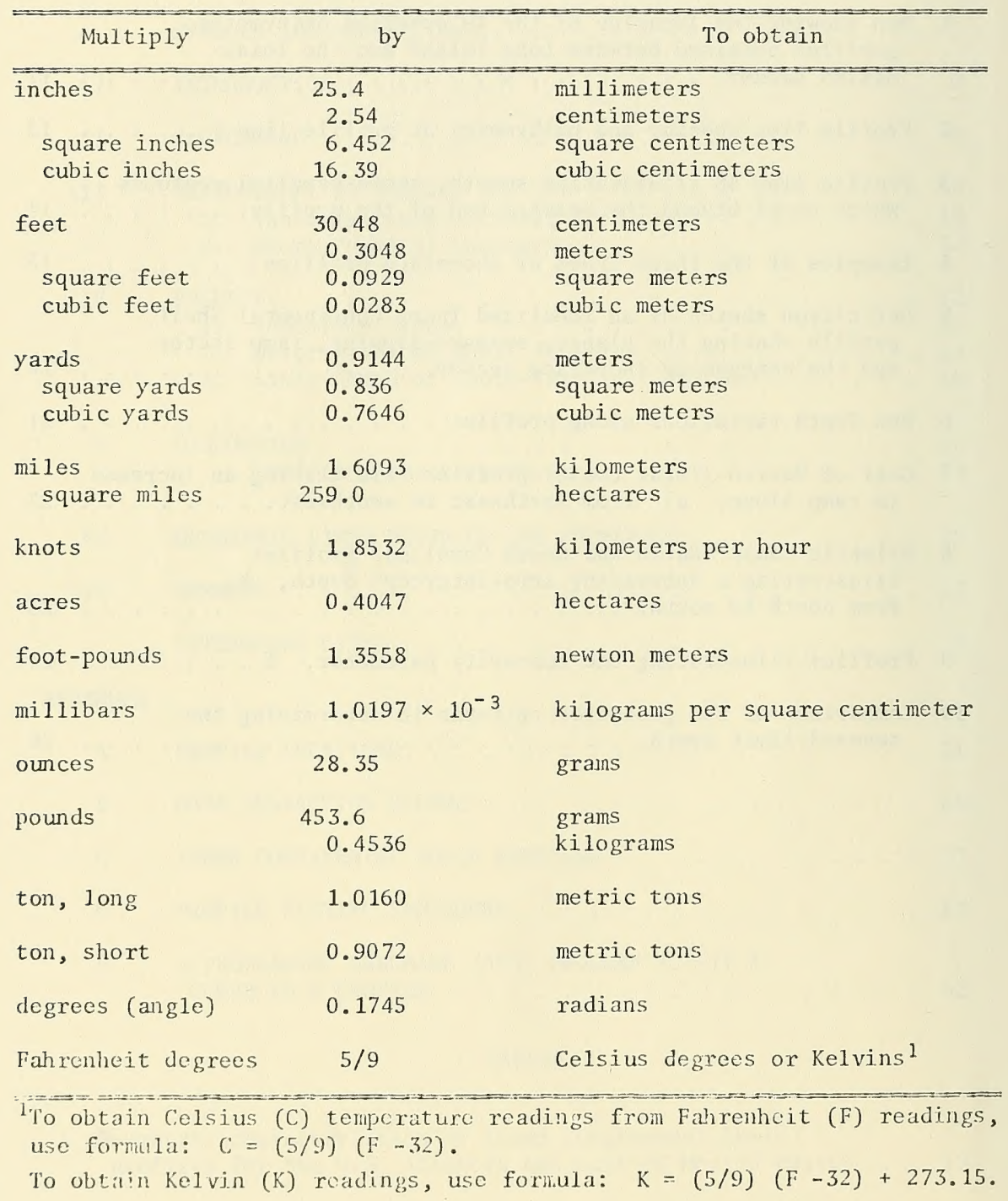


ramp slope

ramp: depth at $\mathrm{x}=0$ wisen the ramp is extended to 1 lic: mean low waler (Ml, $\left.W^{i}\right)$ shoreline

distance from the MI.W shoreline to tlic upper and Jones shoreface boundary; $3 c$ is the distance to the shorefaciramp boundary

prefile depth at seaward boundary of juncr shoreface (c) exponent defining concavity of shoreface

combining term that approximates the influenec of shorefar and ramp in the region $2 c \leq x \leq 3 c$

depth at shoreface-ramp boundary (5c)

concavity index (eq. 1$)-10)$

constants

number of distance statjons in the interval: 300 meters $(1,000 \mathrm{ft}) \leq \mathrm{x} \leq \mathrm{c}$

distance from shorc

distance from shore

bottom depth below MLW datum

actual depth value at $x_{i}$

calculated depth valuc at $x_{i}$

ramp dept.h

shoreface depth 

GEOMETRY OF PROFILES ACROSS INNER CONTINENTAL SHELVES

OF THE ATLANTIC AND GULF COASTS OF THE UNITED STATES

by

Craig H. Everts

\section{INTRODUCTION}

A bathymetric profile, when projected over the Inner Continental Shelf along most coastlines, displays a characteristic shape. The profile, which is the intersection of the shelf bottom with a vertical plane, is typically steep and concave-up near the coast. Farther seaward it is generally planar with a gradual slope away from the coast. Price (1954) separated this distinctive shelf geometry in the Gulf of Mexico into the riear-coast shoreface sector and the more seaward ramp sector.

The geometric nature of the Inner Continental Shelves along open and straight parts of the middle and southern Atlantic coast, and the Gulf of Mexico coast, is described and quantified in this report. Forty-nine shore-normal bathymetric profiles, at about a 100-kilometer (62.5 miles) spacing. are presented. Each profile represents an average of nine profiles taken along 12 kilometers (7.6 miles) of adjacent coast. The shoreface and ramp sectors are discussed separately because geometric evidence suggests the possibility of a different origin for the two sectors. A means to approximate the two-part Inner Continental Shelf profile as a function of easily obtained profile elements is developed, and procedures to select the seaward-1imiting depth of the shoreface are suggested and evaluated.

\section{BACKGROUND}

One means of describing the Inner Continental Shelf profile is to consider the profile as a continuous element. Bruun (1954), for example, used a single-power-function in a study of shelf profiles along the Danish and California coasts.

Hayden, et al. (1975) applied an eigenvector method of analysis to identify the characteristic forms of profiles to a distance of 365 meters (1,200 feet) offshore. Resio, et al. (1974) also used an eigenvector analysis to characterize bathymetric variability in profile shape, but to a greater distance offshore along the Atlantic and gulf coasts. Resio, et al. discussed the two-segment form of the profiles, but chose to analyze them as continuous features. They noted that the break in profile shape from curvilinear to linear occurred in water depths of 9 to 25 meters (30 to 80 feet) and always within 14 kilometers ( 8.7 miles) of the shoreline. They also reported that the profile break may represent a transition from a wave-dominated bottom region near the coast to an offshore region where the wave influence is less. 
The Inner continental Shelf proftlo was viewed as a two-element shape by Johnson (1919) and Fisher (1973). In discussing the origir of harrier islands, both made extensive use of the planar ramp sector as it extended through or under the shoreface sector. Shepard (1963) presented evidence from borings obtained along the Gulf of Mexico coast that indicated the shoreface of some barrier islands grew upward on the cxtended ramp as sea level rose. Sheridan, Dill, and Kraft (1974) reported that the Delaware barrier island shoreface migrated westward across and above large lagoonal complexes. This westward transgression of the shoreface was on an undulating crosion surface, or ramp, with a gentle slope toward the offshore.

Field and Iluane $(1974,1976)$ also presented evidence that some barrier islands originated seaward of their present positions, and are presently shifting landward. Using seismic evidence they show that shoreface sectors are structurally different from the ramp sectors and are sometimes superimposed upon a landward extension of the ramp. In a study of the inner shelf near Cape Canaveral, Florida, they found that shallow subbottom strata on the ramp were truncated by a transgressing sea, creating a flat-lying reflector. The shoreface sector now lies above this reflector. No relationship was found between the slope of the reflector and the present nearshore configuration.

Results of field studies such as Sheridar, Dill, and Kraft (1974) and Field and Duane $(1974,1976)$ suggest the geometrically different ramp and shoreface are also genetically different. For this reason, the following empirical approach to define the Inner Continental Shelf profile includes separate descriptions of the ramp and shoreface, and a means to couple the two.

\section{I . MEASUREMENT PROCEDURE}

\section{Inner Continental Shelf Profiles.}

A total oi 441 bathymetric profiles from 49 coastal localities was assembled for this study, using National Ocean Survey (NOS) (formerly U.S. Coast and Geodetic Survey) 1200 series hydrographic charts. Nine profiles from each locality were averaged to obtain a single representative profile (Fig. 1). Localities were chosen according to their location on straight, uninterrupted coasts as distant as possible from inlets, estuaries, or river entrances, and to nearshore regions (up to 10- to 15meter (30 to 45 feet) water depths) that displayed relatively smooth bathymetric contours parallel to shore. In all instances, profile locations were selected with a $150^{\circ}$ land-free arc for a 500-kilometer (312 miles) radius away from the coast. Additionally, locations were selected where bottom materials were unconsolidated as indicated by sediment symbols on the charts. Most of the profiles were obtained from barrier island coastlines.

At the center of each locality a profile line was drawn on the chart along an azimuth normal to and away from the coast. The latitucle and 


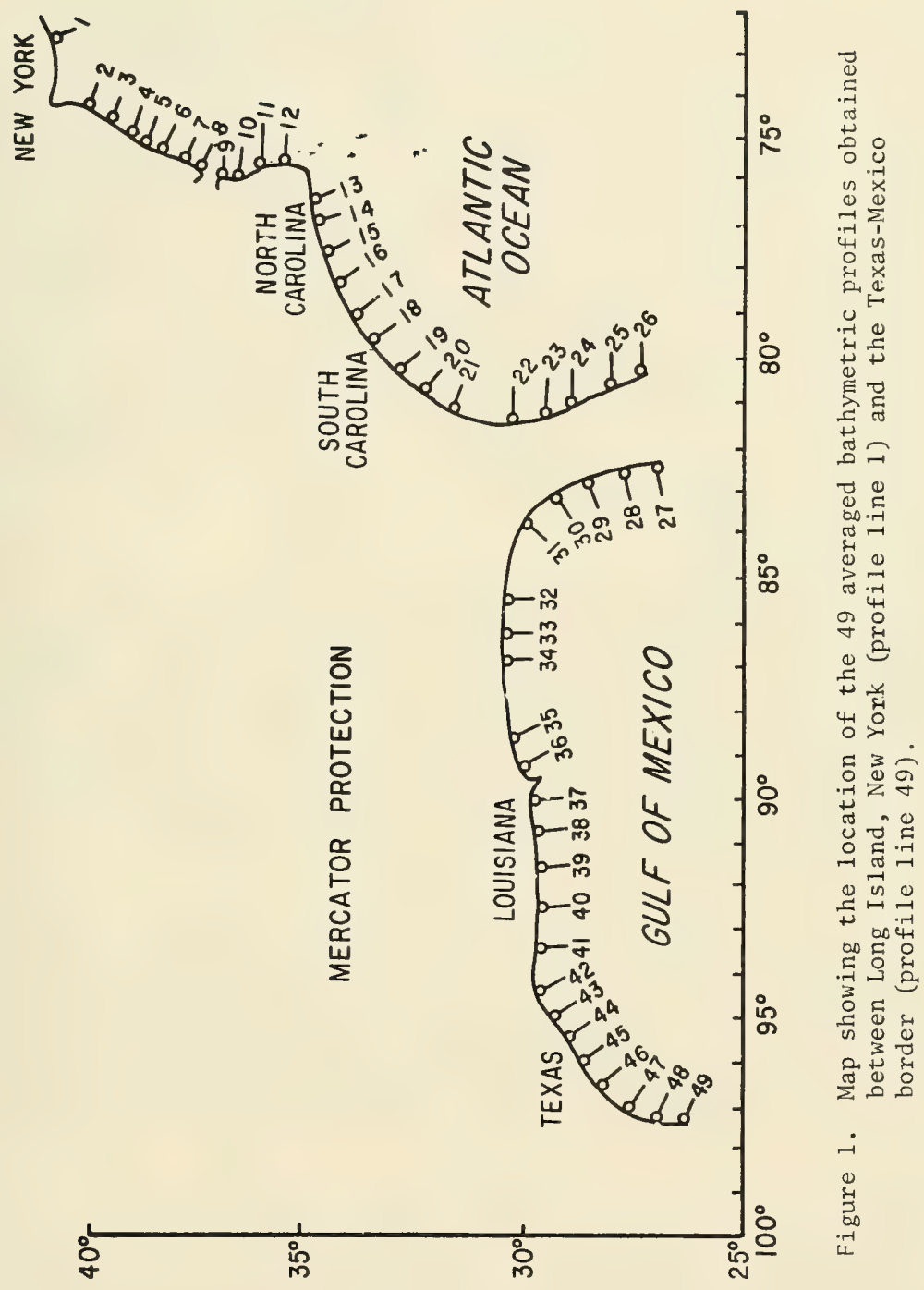


longitude of the shoreline intercept of the line were recorded to one one-hundredths of a minute (see App. A). Four additional profile lines spaced at 1.5 kilometers $(5,000$ feet) were drawn upcoast and four were drawn downcoast parallel to the centerline (App. B). This resulted in a set of nine profile lines at equal spacing along 12 kilometers of coast. Each profile 1 ine was extended seaward 30.5 kilometers (19 miles) from the mean low water (MLW) shoreline. Depths were obtained from the charts using an acetate overlay on which marks were scribed at 30 stations, graduated in increasing distance intervals from the zero-depth position (App. B). Higher resolution was used near the shore because wave action tends to create greater slopes there. Selection of the station intervals was also based on the typical frequency distribution of depth variations on the charts between stations away from the coast. Figure 2 is an example of the profile line spacing and bathymetry on a 1200 series chart. At each locality an arithmetic mean depth was derived for each of the 30 distance stations by averaging depth values from all 9 profiles. The resultant mean profile constituted the basic data used in the study. These profiles are in Appendix $C$. Unless otherwise stated, further references to profiles in this report refer to the average of nine profiles.

\section{Shore Parallel Contours.}

For comparison with the location of the shoreface-ramp boundary obtained using the profiles, the seaward limit of shore-parallel contours was measured at the center of each of the 49 localities where depth-distance data were averaged. The seaward limit was defined as the transition depth where bathymetric contours changed from smooth and shore-parallel to irregular or no longer shore-parallel. All seawardlimit values were obtained using the same 1200 series charts used in selecting depth-distance pairs. Figure 2 illustrates a shelf location with an abrupt transition from shore-parallel to irregular contour; a smooth, shore-parallel contour is shown in Figure 3 .

At 31 of the 49 localities the root mean square (rms) (standard deviation) of the nine depth values for each of the 30 distance stations was also computed. This was done to determine if there was a less subjective way than that previously described to determine where contour irregularity replaces shore-parallelism. The thesis was that the deviation about the mean of depths obtained at constant distances from shore would reflect the change from the shore profile to the region of offshore (ramp) irregularity.

\section{IV . RESULTS}

\section{Shoreface Types.}

Three types of shoreface profile predominated (Fig. 4), but the ramp shape (planar, seaward-dipping) was similar on all profiles. The shoreface varied about a profile which smoothly coupled with the ramp as shown for profile line 15. Two extreme cases of shoreface-ramp coupling are also 


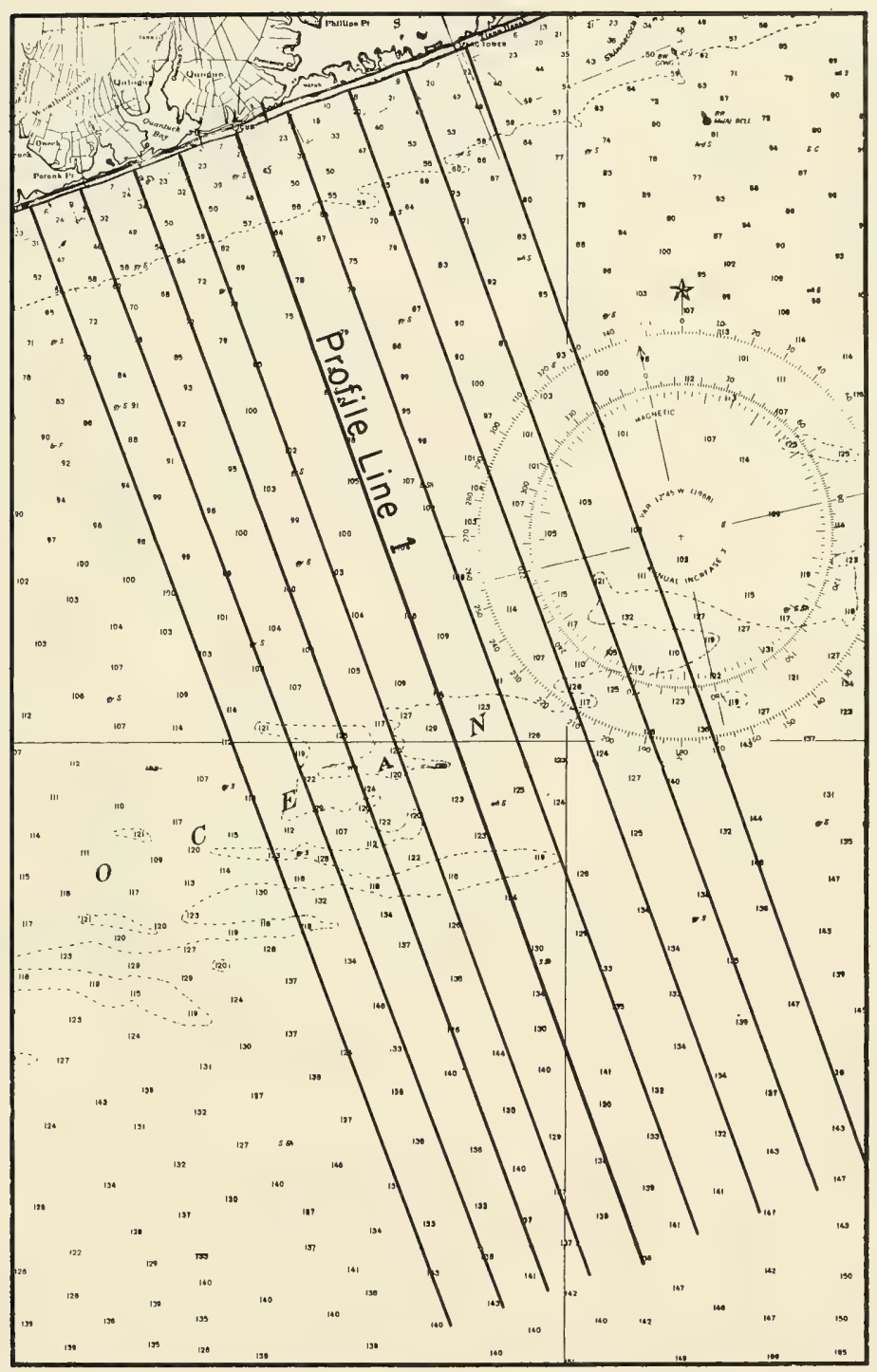

Figure 2. Profile line spacing and bathymetry at profile line 1. Note the abrupt change in contour orientation, from smooth and shore-parallel to irregular, at a distance of 12 kilometers (7.6 miles) from shore (NOS Chart 1214). 


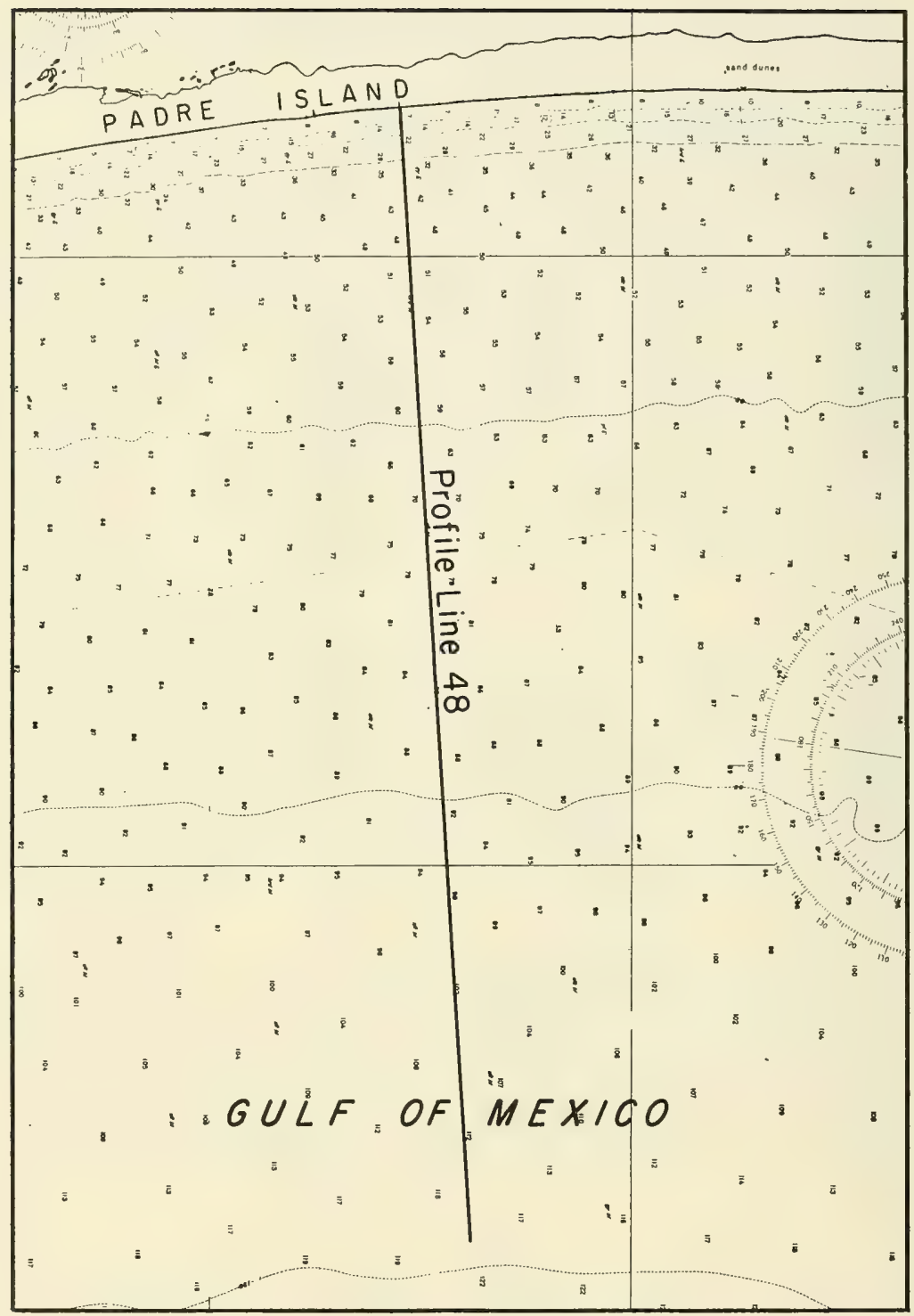

Figure 3. Profile line 48 illustrating smooth, shore-parallel contours which exist beyond the seaward end of the profile (NOS Chart 1287). 


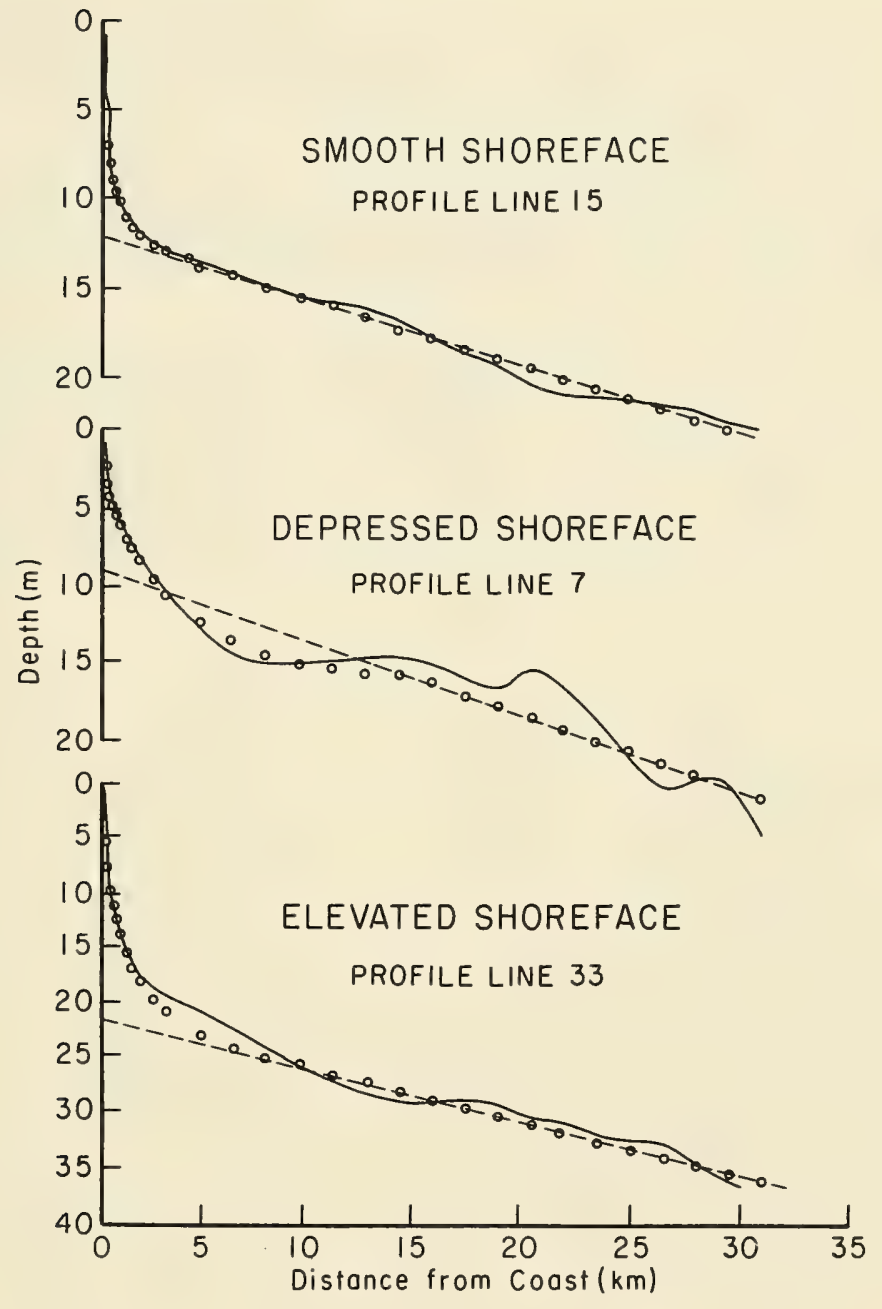

Figure 4. Examples of the three types of shoreface profiles. Profiles as obtained from NOS charts are shown as solid lines. Dashlines represent the smoothed ramp profile extended to the coastline. Circles represent points on a profile mathematically fitted to the actual profile. The vertical exaggeration is X 500 . 
shown. Profile line 7 illustrates a depressed lower shoreface region which lies below the landward ramp extension. Profile line 33 represents an elevated lower shoreface which lies above the ramp extension.

\section{Description of Shelf Profiles.}

A procedure developed to mathematically describe the profile shape is given in Apperdix. D.. Thie procedure utilizes data obtained from the profile locations listed in Appendix A. As shown in Figure 5, three boundary points are defined on the profile, as follows:

(a) The intersection of MLW and the profile which is assigned distance-elevation coordinates $(0,0)$, i.e., the origin;

(b) the boundary between the upper and lower shoreface which is assigned distance-elevation coordinates (c,d); and

(c) the boundary between the lower shoreface and the ramp which is assigned distance-elevation coordinates $(3 \mathrm{c}, \mathrm{g})$.

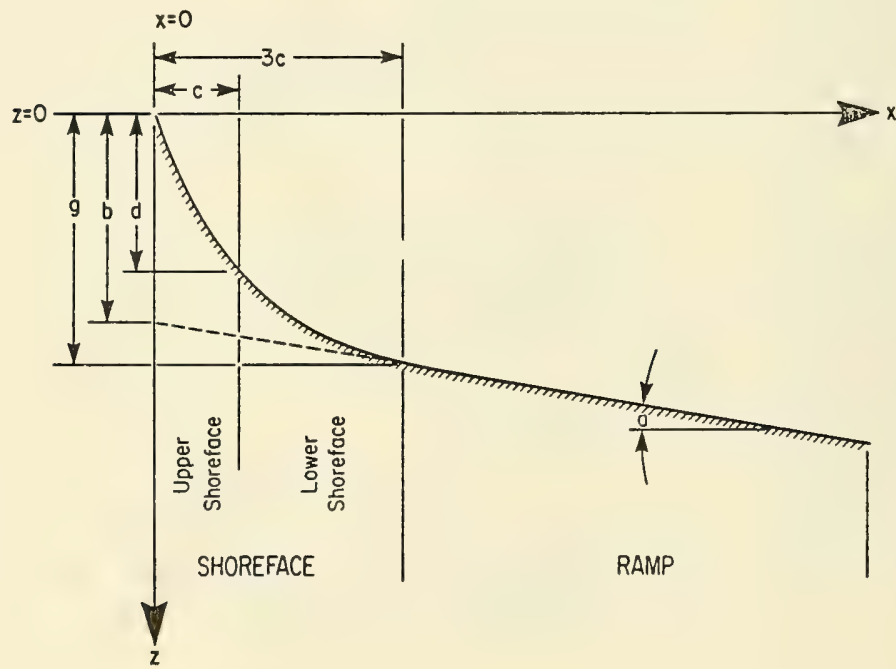

Figure 5. Definition sketch of an idealized Inner Continental Shelf profile showing the planar, seaward-dipping, ramp sector and the concave-up shoreface sector. The horizontal origin, $x=0$, and vertical origin, $z=0$, indicate the MLW shoreline as obtained from NOS 1200 series charts. 
Two additional parameters are considered: $a=$ ramp slope and $b=$ ramp intercept depth at the shoreline (when the straight-line ramp is extended landward to the shoreline). The shoreface-ramp boundary, $3 c$, is the characteristic horizontal distance that is first selected from a profile. However, because irregularities in the shape of the lower part of the shoreface are not uncommon, the region between $c$ and $3 c$ is not useful in evaluating the goodness of fit of a mathematically generated curve to the actual profile (App. D). Consequently, only the upper part of the shoreface was used for that purpose.

The ramp sector is approximated by the equation of a straight line. The shoreface sector is approximated by an exponential curve with the slope steepest near the shore and, usually, the maximum concavity near the ramp. An empirical term combines the shoreface and ramp sectors. The result is the equation

$$
z=(1-G)(a x+b)+G\left(g\left(1-\exp ^{-\frac{x}{c}}\right) f\right)
$$

where

$$
\begin{aligned}
& z=\text { bottom depth below MLW datum } \\
& \mathrm{G}=\text { term to combine the shoreface and ramp sectors } \\
& \mathrm{x}=\text { distance seaward of the shoreline } \\
& \mathrm{g}=\text { depth at shoreface-ramp boundary } \\
& \mathrm{f}=\text { exponent defining concavity of shoreface }
\end{aligned}
$$

$\mathrm{G}$ is defined as

$$
G=\exp \left[-2.8\left(\frac{x}{3 c}\right)^{10}\right]
$$


and

$$
g=3 a c+j
$$

where $g$ is a computed quantity. The concavity parameter is obtained from the figure in Appendix $D$ or

$$
f=2.8\left(1-\frac{d}{g}\right) .
$$

Points on the profiles in Figure 4 and in Appendix $C$ are depthdistance values ohtained using equation (1). The values a, b, c, and d are relatively easy to obtain from the profiles, and appear to provide a first-order mathematical approximation of the profile when used in cquation ( 1 ). Table 1 presents the values of parameters used in equation (1) for each of the 49 profiles (Fig. 1; App. C).

3. Limit Depth of Shore-Parallel Contours.

The seaward Iimit of shore-parallel contours, and the depth where the rms values change significantly are shown in Table 2 . The rms values on the landward parts of the profiles averaged 0.6 to 1.0 meter $(2$ to 3 feet) on profiles along the Atlantic coast, and 0.2 to 0.3 meter $(0.7$ to 1.0 foot) along the Gulf of Mexico coast. The ratio of the rms values of the near-coast profile segment to the rms values farther seaward are given in the table. Figure 6 shows two representative rms depth curves plotted against distance from shore. The curve on profile 1 ine 1 shows a well-defined change in the rms depth values; the profile 1 ine 48 curve suggests no obvious difference in rms along the profile (see bathymetry in Figs. 2 and 3).

\section{DISCUSSION}

Profile Characteristics.

Steep and concave-up shoreface sectors, and gently dipping and planar ramp sectors are ubiquitous off the mid and south Atlantic, and Gulf of Mexico, barrier island coasts. Values of individual geometric slope parameters in many instances tend to vary in a consistent manner in an alongshore direction, or remain constant and exhibit little alongshore variation over a long coastal reach (Table 1). The consistency of trend between different parameters is not so obvious. This is especially true for the properties of the shoreface and ramp which appear to be mostly unrelated.

a. Ramp Slope. The ramp slope, a (Table 1), in the direction normal to shore, varies only slightly from the mean slope of 0.00041 along most of the Atlantic coast. However, as the Continental Shelf 
Table 1. Geometric characteristics of Inner Continental Shelf profiles for the U.S. Atlantic and Gulf of Mexico coasts.

\begin{tabular}{|c|c|c|c|c|c|c|c|}
\hline Profile & $\begin{array}{l}\text { Ramp } \\
\text { slope, a }\end{array}$ & $\begin{array}{l}\text { Ramp } \\
\text { intercept } \\
\text { depth, b } \\
(\mathrm{m})\end{array}$ & $\begin{array}{c}\text { Distance to } \\
\text { shoreface-ramp } \\
\text { boundary, 3c } \\
(\mathrm{km})\end{array}$ & $\begin{array}{c}\text { Depth at } \\
\text { shoreface-ramp } \\
\text { boundary, } g \\
\text { (m) }\end{array}$ & $\begin{array}{l}\text { Concavity } \\
\text { parameter, f }\end{array}$ & $\begin{array}{c}\text { Ramp } \\
\text { correlation } \\
\text { coefficient }\end{array}$ & $\begin{array}{l}\text { Shoreface } \\
\text { residual } \\
\left(\mathrm{m}^{2}\right)\end{array}$ \\
\hline $\begin{array}{r}1 \\
2 \\
3 \\
4 \\
5 \\
6 \\
7 \\
8 \\
9 \\
10\end{array}$ & $\begin{array}{l}0.00065 \\
0.00051 \\
0.00044 \\
0.00047 \\
0.00045 \\
0.00039 \\
0.00049 \\
0.00051 \\
0.00028 \\
0.00022\end{array}$ & $\begin{array}{r}24.7 \\
15.2 \\
11.0 \\
7.9 \\
13.1 \\
13.1 \\
8.8 \\
6.1 \\
11.9 \\
18.0\end{array}$ & $\begin{array}{r}20.6 \\
8.2 \\
16.0 \\
11.4 \\
3.2 \\
6.4 \\
16.0 \\
5.0 \\
3.2 \\
20.6\end{array}$ & $\begin{array}{r}38.1 \\
19.4 \\
18.0 \\
13.3 \\
14.5 \\
15.6 \\
16.6 \\
8.7 \\
12.8 \\
22.5\end{array}$ & $\begin{array}{l}0.62 \\
0.34 \\
0.81 \\
0.45 \\
0.65 \\
0.51 \\
0.55 \\
1.41 \\
0.77 \\
0.54\end{array}$ & $\begin{array}{l}0.968 \\
0.985 \\
0.992 \\
0.893 \\
0.848 \\
0.778 \\
0.900 \\
0.969 \\
0.976 \\
0.729\end{array}$ & $\begin{array}{l}0.029 \\
0.696 \\
0.032 \\
0.310 \\
0.012 \\
0.025 \\
0.039 \\
0.012 \\
0.035 \\
0.056\end{array}$ \\
\hline $\begin{array}{l}11 \\
12 \\
13 \\
14 \\
15 \\
16 \\
17 \\
18 \\
19 \\
20\end{array}$ & $\begin{array}{l}0.00038 \\
0.00053 \\
0.00081 \\
0.00039 \\
0.00036 \\
0.00033 \\
0.00031 \\
0.00024 \\
0.00036 \\
0.00039\end{array}$ & $\begin{array}{r}17.1 \\
15.5 \\
14.3 \\
12.5 \\
11.9 \\
11.6 \\
7.9 \\
8.2 \\
6.4 \\
7.0\end{array}$ & $\begin{array}{r}6.4 \\
11.4 \\
5.0 \\
5.0 \\
4.1 \\
3.2 \\
2.5 \\
5.0 \\
2.5 \\
3.2\end{array}$ & $\begin{array}{r}19.5 \\
21.6 \\
18.4 \\
14.5 \\
13.4 \\
12.7 \\
8.7 \\
9.4 \\
7.3 \\
8.3\end{array}$ & $\begin{array}{l}0.60 \\
0.69 \\
0.81 \\
0.31 \\
0.42 \\
0.54 \\
0.42 \\
0.47 \\
1.20 \\
1.72\end{array}$ & $\begin{array}{l}0.911 \\
0.975 \\
0.979 \\
0.998 \\
0.987 \\
0.993 \\
0.981 \\
0.989 \\
0.980 \\
0.976\end{array}$ & $\begin{array}{l}0.179 \\
0.061 \\
0.073 \\
0.566 \\
0.169 \\
0.009 \\
0.003 \\
0.021 \\
0.032 \\
0.076\end{array}$ \\
\hline $\begin{array}{l}21 \\
22 \\
23 \\
24 \\
25 \\
26 \\
27 \\
28 \\
29 \\
30\end{array}$ & $\begin{array}{l}0.00045 \\
0.00042 \\
0.00000 \\
0.00011 \\
0.00036 \\
0.00098 \\
0.00052 \\
0.00050 \\
0.00026 \\
0.00039\end{array}$ & $\begin{array}{r}4.3 \\
11.3 \\
19.8 \\
16.8 \\
14.6 \\
5.5 \\
7.3 \\
5.5 \\
0.6 \\
0.0\end{array}$ & $\begin{array}{r}2.5 \\
11.4 \\
16.0 \\
11.4 \\
11.4 \\
4.1 \\
3.2 \\
4.0 \\
0.2 \\
0.7\end{array}$ & $\begin{array}{r}5.4 \\
16.1 \\
19.8 \\
18.1 \\
18.7 \\
9.5 \\
9.0 \\
7.6 \\
-0.2 \\
0.3\end{array}$ & $\begin{array}{l}1.16 \\
0.30 \\
0.24 \\
0.27 \\
0.33 \\
0.25 \\
0.38 \\
0.27 \\
-. .22 \\
0.38\end{array}$ & $\begin{array}{l}0.995 \\
0.964 \\
0.926 \\
0.613 \\
0.987 \\
0.991 \\
0.992 \\
0.984 \\
0.929 \\
0.997\end{array}$ & $\begin{array}{l}0.011 \\
0.092 \\
0.338 \\
0.754 \\
0.118 \\
0.965 \\
0.013 \\
0.016 \\
0.000 \\
0.000\end{array}$ \\
\hline $\begin{array}{l}31 \\
32 \\
33 \\
34 \\
35 \\
36 \\
37 \\
38 \\
39 \\
40\end{array}$ & $\begin{array}{l}0.00038 \\
0.00072 \\
0.00052 \\
0.00060 \\
0.00011 \\
0.00065 \\
0.00104 \\
0.00051 \\
0.00011 \\
0.00026\end{array}$ & $\begin{array}{r}0.3 \\
6.4 \\
21.9 \\
17.1 \\
14.9 \\
3.4 \\
4.3 \\
9.5 \\
4.3 \\
8.8\end{array}$ & $\begin{array}{r}0.7 \\
2.1 \\
6.4 \\
6.4 \\
16.0 \\
3.2 \\
11.4 \\
11.4 \\
10.6 \\
29.7\end{array}$ & $\begin{array}{r}0.6 \\
7.9 \\
25.2 \\
20.9 \\
16.7 \\
5.5 \\
16.2 \\
15.3 \\
5.5 \\
34.6\end{array}$ & $\begin{array}{l}1.09 \\
0.21 \\
0.55 \\
0.37 \\
0.44 \\
0.89 \\
1.17 \\
1.36 \\
0.99 \\
0.86\end{array}$ & $\begin{array}{l}0.998 \\
0.990 \\
0.973 \\
0.930 \\
0.684 \\
0.931 \\
0.998 \\
0.960 \\
0.958 \\
0.972\end{array}$ & $\begin{array}{l}0.000 \\
0.025 \\
0.479 \\
0.792 \\
0.007 \\
0.034 \\
0.000 \\
0.119 \\
0.000 \\
0.004\end{array}$ \\
\hline $\begin{array}{l}41 \\
42 \\
43 \\
44 \\
45 \\
46 \\
47 \\
48 \\
49\end{array}$ & $\begin{array}{l}0.00018 \\
0.00019 \\
0.00022 \\
0.00049 \\
0.00046 \\
0.00061 \\
0.00067 \\
0.00074 \\
0.00107\end{array}$ & $\begin{array}{r}7.3 \\
9.8 \\
12.5 \\
9.8 \\
11.0 \\
9.8 \\
12.5 \\
13.4 \\
7.6\end{array}$ & $\begin{array}{r}10.6 \\
16.0 \\
25.1 \\
11.4 \\
11.4 \\
6.4 \\
6.4 \\
8.2 \\
5.0\end{array}$ & $\begin{array}{r}9.2 \\
12.8 \\
18.0 \\
15.4 \\
16.2 \\
13.7 \\
16.8 \\
19.5 \\
12.8\end{array}$ & $\begin{array}{l}1.00 \\
0.67 \\
0.61 \\
0.76 \\
0.71 \\
0.75 \\
0.94 \\
0.82 \\
0.65\end{array}$ & $\begin{array}{l}0.965 \\
0.949 \\
0.896 \\
0.956 \\
0.990 \\
0.999 \\
0.998 \\
0.993 \\
0.992\end{array}$ & $\begin{array}{l}0.000 \\
0.009 \\
0.020 \\
0.012 \\
0.011 \\
0.004 \\
0.011 \\
0.008 \\
0.035\end{array}$ \\
\hline
\end{tabular}

${ }^{1}$ See Figure 1 for locations.

${ }^{2}$ Not available. 
Table 2. Shoreface-ramp depths on Inner Continental Shelf profiles.

\begin{tabular}{|c|c|c|c|c|c|}
\hline Profile & $\begin{array}{l}\text { Depth at } \\
\text { shoreface-ramp } \\
\text { boundary } \\
(\mathrm{m})\end{array}$ & $\begin{array}{c}\text { Shoreface } \\
\text { type }\end{array}$ & $\begin{array}{l}\text { Rms depth } \\
\text { (m) }\end{array}$ & $\frac{\text { Rms landward sector }}{\text { Rms seaward sector }}$ & $\begin{array}{l}\text { Shore-parallel } \\
\text { isobath limiting } \\
\text { depth } \\
\text { (m) }\end{array}$ \\
\hline 1 & 38.1 & Smooth & 32.0 & 0.43 & 22.9 \\
\hline 2 & 19.4 & Depressed & 21.0 & 0.63 & 15.2 \\
\hline 3 & 18.0 & Smooth & 17.0 & 0.50 & 4.9 \\
\hline 4 & 13.3 & Depressed & & & 3.7 \\
\hline 5 & 14.5 & Elevated & 17.0 & 0.69 & 3.0 \\
\hline 6 & 15.6 & Smooth & $12 / 15^{1}$ & $0.50 / 0.68$ & 10.7 \\
\hline 7 & 16.6 & Depressed & $15 / 15$ & $0.47 / 0.55$ & 3.7 \\
\hline 8 & 8.7 & Elevated & & & 7.6 \\
\hline 9 & 12.8 & Elevated & & & 5.8 \\
\hline 10 & 22.5 & Smooth & 11.5 & 0.48 & 9.1 \\
\hline 11 & 19.5 & Elevated & 10.0 & 0.46 & 9.5 \\
\hline 12 & 21.6 & Elevated & 8.0 & 0.43 & 9.8 \\
\hline 13 & 18.4 & Smooth & 8.5 & 0.47 & 9.1 \\
\hline 14 & 14.5 & Depressed & $\ldots-2$ & $\approx 1.00$ & 15.2 \\
\hline 15 & 13.4 & Smooth & $---^{2}$ & $\simeq 1.00$ & 14.0 \\
\hline 16 & 12.7 & Smooth & & & 5.5 \\
\hline 17 & 8.7 & Elevated & $----^{2}$ & $\simeq 1.00$ & 5.5 \\
\hline 18 & 9.4 & Elevated & & & 3.7 \\
\hline 19 & 7.3 & Elevated & & & 3.7 \\
\hline 20 & 8.3 & Elevated & & & 1.8 \\
\hline 21 & 5.4 & Elevated & 3.0 & 0.75 & 0.0 \\
\hline 22 & 16.1 & Depressed & 16.0 & 0.50 & 11.0 \\
\hline 23 & 19.8 & Depressed & 20.0 & 0.35 & 15.9 \\
\hline 24 & 18.1 & Depressed & 18.0 & 0.55 & 12.5 \\
\hline 25 & 18.7 & Smooth & 17.0 & 0.66 & 14.0 \\
\hline 26 & 9.5 & Depressed & 11.5 & 0.52 & 11.9 \\
\hline 27 & 9.0 & Smooth & 8.5 & 0.70 & 5.5 \\
\hline 28 & 7.0 & Depressed & & & 3.7 \\
\hline 29 & $\ldots-3$ & 4 & & & 0.0 \\
\hline 30 & 0.3 & $\ldots-n$ & & & 0.0 \\
\hline 31 & 0.6 & $\ldots$ & 2.0 & 0.46 & 0.0 \\
\hline 32 & 7.9 & Depressed & & & 6.1 \\
\hline 33 & 25.2 & Elevated & 18.0 & 0.71 & 11.0 \\
\hline 34 & 20.9 & Depressed & 23.0 & 0.58 & 15.2 \\
\hline 35 & 16.7 & Smooth & & & 10.4 \\
\hline 36 & 5.5 & Depressed & & & 7.3 \\
\hline 37 & 16.2 & Smooth & & & $>54.9^{5}$ \\
\hline 38 & 15.3 & Smooth & & & $>36.6^{5}$ \\
\hline 39 & 5.5 & Smooth & & & 4.6 \\
\hline 40 & 14.6 & Smooth & 5.5 & 0.63 & $>18.3^{5}$ \\
\hline 41 & 9.2 & Smooth & & & $>18 \cdot 3^{5}$ \\
\hline 42 & 12.8 & Smooth & 8.5 & 0.75 & 15.5 \\
\hline 43 & 18.0 & Smooth & 14.0 & 0.79 & 14.3 \\
\hline 44 & 15.4 & Smooth & & & 16.5 \\
\hline 45 & 16.2 & Elevated & $----^{2}$ & $\approx 1.00$ & 24.4 \\
\hline 46 & 13.7 & Smooth & & & $>45.7^{5}$ \\
\hline 47 & 16.8 & Elevated & 14.0 & 0.50 & $>54.9^{5}$ \\
\hline 48 & 19.5 & Elevated & $-\cdots-2$ & $\approx 1.00$ & $>39.6^{5}$ \\
\hline 49 & 12.8 & Depressed & $---^{2}$ & $\approx 1.00$ & 17.1 \\
\hline
\end{tabular}

${ }^{1}$ Two seaward-limit locations.

${ }^{2}$ No variation in rms along profile.

${ }^{3}$ Not available.

${ }^{4}$ No significant shoreface.

${ }^{5}$ Isobaths shore-parallel to edge of chart. 

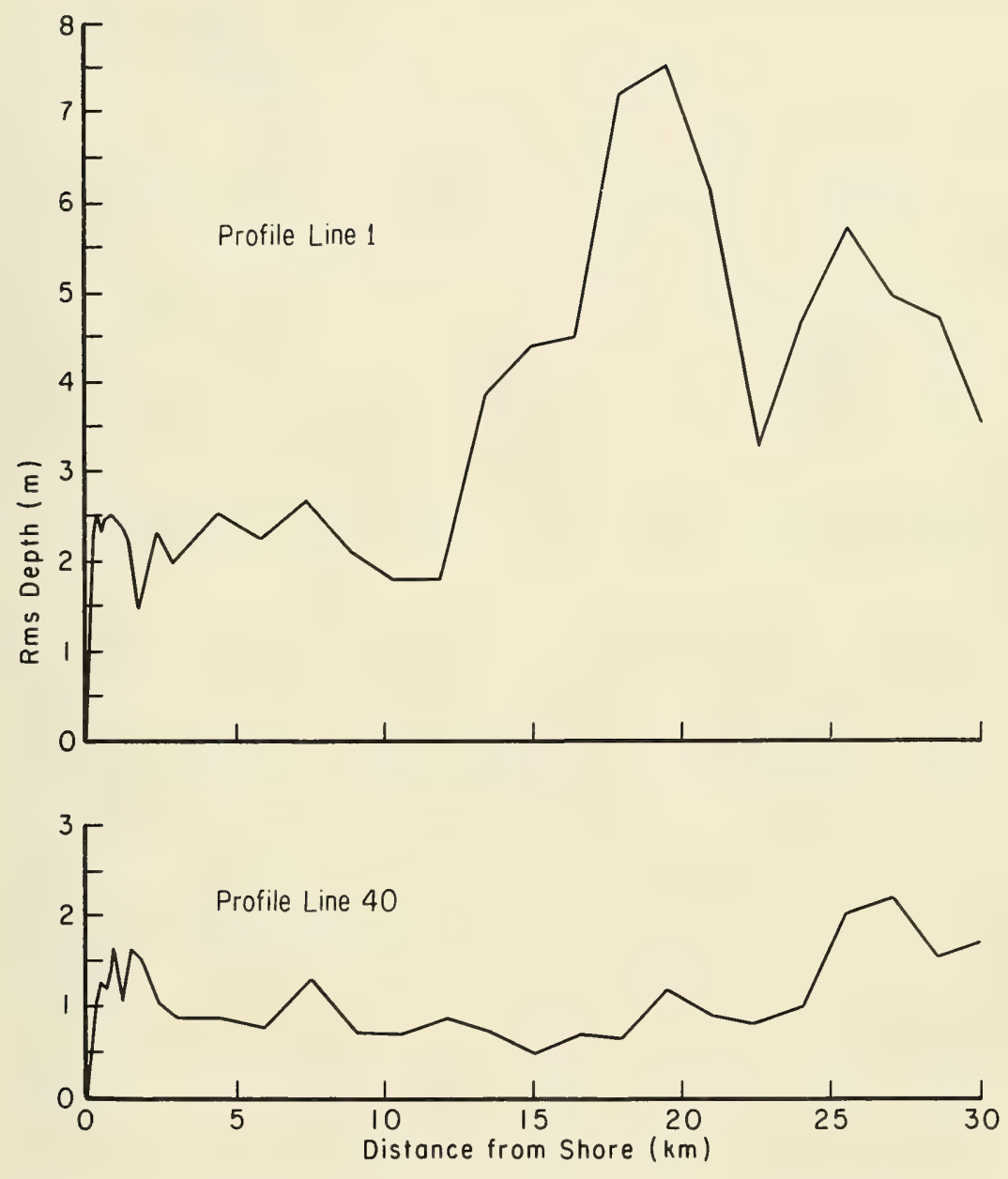

Figure 6. Rms depth variations along profiles. Note distinct change in values at 12.5 kilometers (32-meter depth) on profile line 1 , and lack of significant change along profile line 48 . 
narrows from north to south along eastern Florida, the slope increases from about zero to 0.00098 (profile lines 23 to 26). From east Texas to west Texas (profile lines 39 to 49), the ramp slope progressively increases from 0.00011 to 0.00107 (Fig. 7). Little difference was found when the ramp slope normal to the shelf break was calculated.

b. Ramp Intercept Depth. Alongshore trends in the intercept depth of the ramp at the shoreline, $b$, are evident in Table 1. From Cape Hatteras to Georgia (profile lines 13 to 21) the depth of the ramp when extended to the shoreline decreases fourfold from 14.3 to 4.3 meters (47 to 14 feet) (Fig. 8). Along the Florida coast the intercept depth decreases from 19.8 to 5.5 meters (65 to 18 feet) in a southerly direction (profile lines 23 to 26). Along the western and northwestern coast of Florida the intercept depth is almost zero. This region, which has little wave activity, is where the shoreface is absent or very narrow and the ramp extends nearly to the shoreline. Along the Texas coast (profile lines 40 to 49 ), the intercept depth varies randomly between 7.3 and 13.4 meters (24 to 44 feet), averaging 10.4 meters (34 feet). The ramp slope along the same coast increases sixfold to the southwest, suggesting the shelf surface slope and present shoreline position are probably not genetically related.

c. Shoreface-Ramp Boundary. An accurate distance to the shorefaceramp boundary, $3 c$, is difficult to determine because the sectors appear to join asymptotically, and on a very gradual slope (App. C). A further complication in determining the distance exists because the lower shoreface is not always smooth (Fig. 4). There was no significant shoreface on 3 profiles (profile lines 29, 30, and 31); 19 profiles exhibited a smooth lower shoreface; 13 were depressed types; and 14 were elevated.

The depth at the shoreface-ramp boundary, g (Table 1), displays a greater profile-to-profile similarity, or progressive alongshore change, than does the distance to the.boundary. For example, between profile line 10 and profile line 21 , the boundary depth progressively decreased from 19.5 to 4.7 meters (64 to 15 feet) (Fig. 8); the distance to the boundary did not exhibit as significant a trend. Because the shoreface and ramp appear genetically different, at least in some areas, the boundary location is important. It may designate the cutoff region of significant active modification of the profile by present wave and current processes. It may also delimit the zone seaward, where man-caused or natural profile changes will not produce a sympathetic effect on the coastal beaches.

d. Shoreface Concavity. Concavity, f (Table 1), indicates the deviation of the shoreface slope from planar. A highly concave-up (depressed) shoreface is represented by a low concavity value (Fig. 9). An elevated shoreface will exhibit a larger concavity value. A concavity value above $f=1.87$ represents a convex shoreface slope, but no such case occurred in the profiles. Along the Texas coast concavity values are near constant $(0.8)$ and twice as large as the Atlantic coast values. Concavity is to some extent dependent on the energy distribution of waves acting upon the profile. 


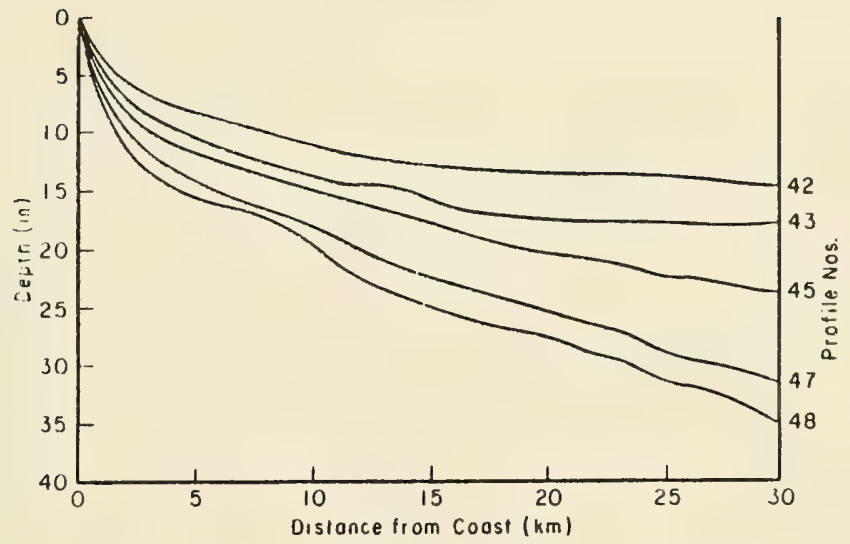

Figure 7. Gulf of Mexico ('Texas coast) profiles illustrating an increase in ramp slope, i. from northeast to southwest.

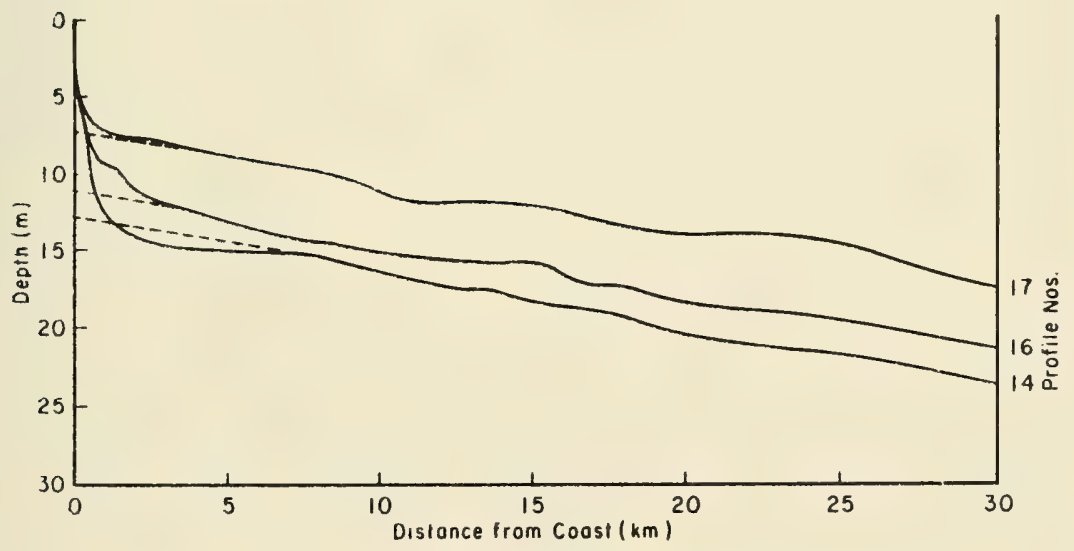

Figure 8. Atlantic coast (North and South Carolina) profiles illustrating a decreasing zerointercept depth, b, from north to south. The dashlines show the ramp slope extended landward to the coast. 


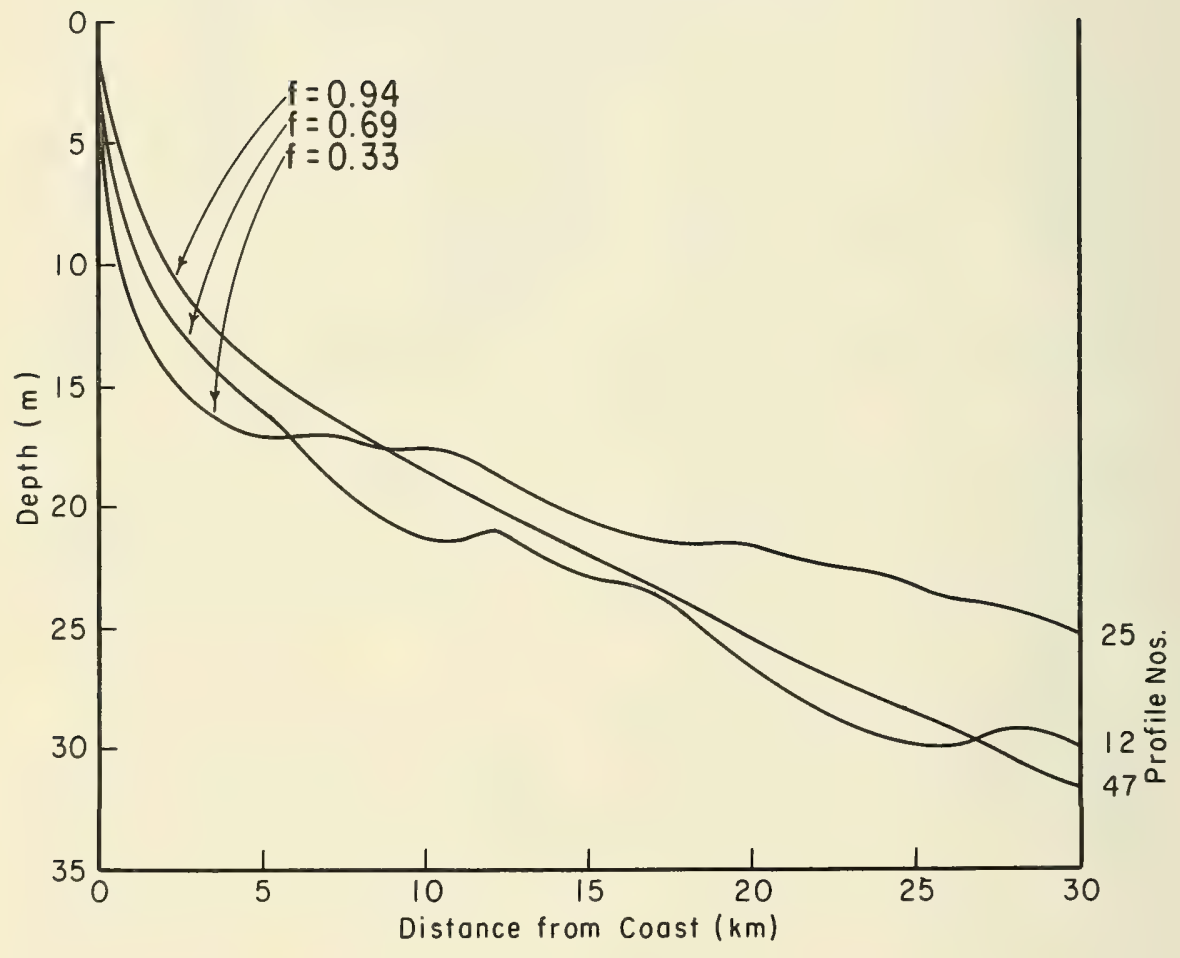

Figure 9. Profiles illustrating the concavity parameter, $f$. 


\section{GEOMETRIC LIMIT DEPTH OF THE SHOREFACE}

Changes in the volume of sand on a beach are related, in part, to changes in the volume of sand and the profile shape farther seaward. Neglecting longshore transport, sand may move onto the beach from sources farther seaward, or may be supplied to the seaward region from beach sources. Wave action initiates most of the sand movement. Currents, either wave-produced or resulting from other mechanisms, transport the sand. There is presently an increasing interest in the seaward limit beyond which sand will no longer move to or from the beach, or beyond which changes in bathymetry will not affect processes on the beach. This interest is primarily directed toward the use of offshore sand sources for beach fill. For example, if sediment is removed fxom the Inner Continental Shelf between the seaward limit and the foredune, i.e., the region often defined as the active profile, the excavation may subsequently fil1, possibly with sand that originated near or on the beach, thereby contributing to a decrease of sand on the beach. Conversely, sediment artificially placed on the active profile will likely move in such a manner that the profile will tend toward an equilibrium shape for the waves acting upon sand of that size, shape, and density. Thus, sand may be placed seaward of the beach during certain times of the year with the expectation it will ultimately move landward to nourish the beach. If placed seaward of the seaward limit, or at a time when it moves beyond the seaward limit, the sand will not fulfill the purpose of the dumping. Additionally, in calculating the sediment budget of a coastal area where sediment volume changes are occurring, the seaward limit of sediment movement is a required parameter. One of its practical uses comes in predicting the volume of sand needed to artificially extend the shoreline while keeping the active profile in equilibrium.

The data in this report may be used when two general geometric procedures are considered in establishing a seaward limit. Each procedure is based wholly on geometric characteristics of the Inner Continental She1f, and not on direct evidence of sediment transport. No evidence is available that indicates the results actually designate a seaward limit of sediment movement.

The geometric criteria that might be useful to establish a limit depth of the shoreface, and possibly a seaward-1imiting depth of significant sediment transport, are (a) depth at the shoreface-ramp intersection, coordinates $(\mathrm{g}, 3 \mathrm{c}$ ) in Figure 5, and (b) depth at the transition from shore-parallel, smooth bathymetric contours near the coast to irregular contours farther offshore (U.S. Army, Corps of Engineers, Coastal Engineering Research Center, 1977). Examples are shown in Figures 2 and 3, and both depths are given in Table 2. As illustrated in Figure 10, the depth of the seawardmost shore-parallel bathymetric contour does not agree well with the seaward-limit depth obtained using the shoreface-ramp criterion. For the Atlantic coast and the gulf coast east of the Mississippi River Delta, the shoreface-ramp criterion depth on 89 percent of the profiles was greater than the depth obtained using the shore-parallel contour criterion. West of the Mississippi River Delta, 85 percent of the shore- 


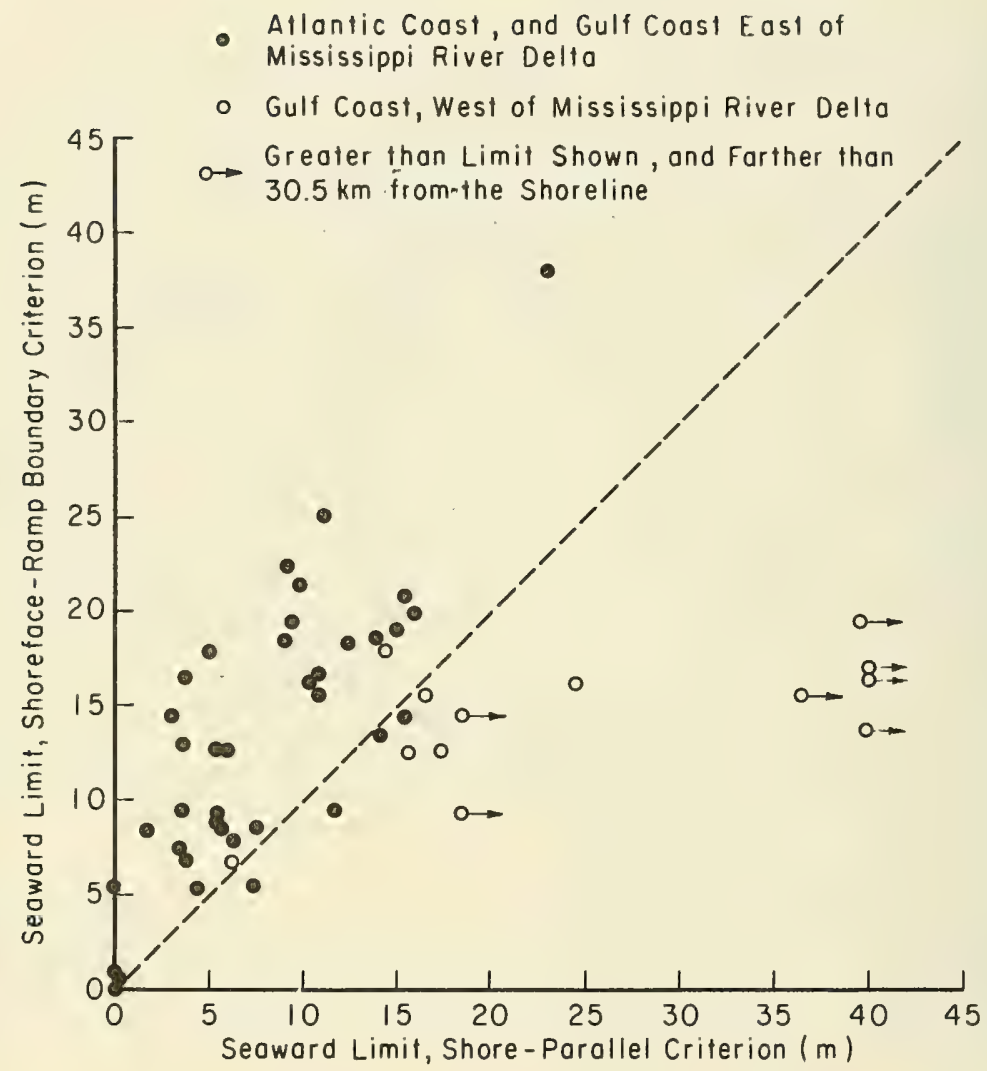

Figure 10. Comparison of the geometric criteria in detcrmining the seaward-1jmit depth (data from Tablo 2). 
parallel criterion depths were larger. Along-coast trends obvious in the seaward-1imit depth using the shoreface-ramp criterion were not as obvious when using the shore-parallel contour criterion (Table 2).

In the western part of the gulf, many contours were shore-parallel past the end of the profiles (30.5 kilometers). A problem in using the shore-paralle1 contour criterion was created because some of the depths beyond which the contours are shore-parallel, exceeded 55 meters (180 feet). This is probably well below the depth of significant sediment transport. In other areas, contour shore-parallelism was lost because of shore-connected shoals. The shoals angle away from the coast, and often begin in quite shallow depths. In most cases, they are probably still part of the active profile. On profile lines 29, 30, and 31 where a shoreface is absent, shore-parallel contours do not exist. No significant offshore sediment transport is suggested in this region of the Florida coast.

The rms depth criterion is a quantitative measure to describe the shore-parallelism of contours. It proved least consistent of any method. It is less subjective than the shore-parallel contour method, but directed at the same boundary; i.e., the transition between shore-paralle 1 and irregular contours. The rms criterion also becomes less useful when the contours are parallel, but oriented at a slight angle relative to the coast.

Results of this study indicate the shoreface-ramp criterion is more consistent in an alongshore direction than the shore-parallel contour criterion. The shoreface-ramp method is also more objective when calculated as discussed in this report. The limiting depth obtained by either method is the depth of the change in shape or smoothness of the Inner Continental Shelf. It may or may not be indicative of the seaward limit of sediment transport to or from the beach.

\section{I . SUMMARY}

1. The Inner Continental Shelf profile along the U.S. Atlantic and Gulf of Mexico coasts exhibits a two-sector shape. Near the coast the shoreface sector is steep and concave-up. Farther seaward, the ramp sector is planar with a gradual slope away from the coast. The steepest slope is near the shore. The largest concavity is near the shorefaceramp boundary.

2. In most cases, no relationship was found between the geometric characteristics of the shoreface and those of the ramp (Table 1 ). Likewise, no relationship was evident in the along-coast trend of the geometric characteristics on the shoreface and those on the ramp. This lack of correlation suggests different origins for these sectors. The shoreface today may be in, or approaching, some form of equilibrium with the existing wave climate, shelf currents, available sediment supply, sea level changes, and other factors; the large-scale ramp bathymetry is 
probabl) iargely a jumctjon of past cucnts. These are jilliceces however, and are not dircetly substantiated by the rati ut il study.

3. The shore-ramp boundary was gercursily not at the $\therefore$ is vert's as the depth at which shore-jayallel connurs ceasc 
BRUUN, P., "Coast Erosion and Development of Beach Profile, TM-44, U.S. Army, Corps of Engineers, Beach Erosion Board, Washington, D.C., June 1954.

FIELD, M.E., and DUANE, D.B., "Geomorphology and Sediments of the Inner Continental Shelf, Cape Canaveral, Florida," TM-42, U.S. Army, Corps of Engineers, Coastal Engineering Research Center, Fort Belvoir, Va., Mar. 1974 .

FIELD, M.E., and DUANE, D.B., "Post Pleistocene History of the United States Inner Continental Shelf: Significance to Origin of Barrier Islands," The Geological Society of America BulZetin, Vo1. 87, No. 5, May 1976, pp. 691-702.

FISCHER, J.J., "Bathymetry Projected Profiles and Origin of Barrier Islands - Johnson's Shoreline of Emergence, Revisited," Coastal Geomorphology, D.R. Coates, ed., Publications in Geomorphology, State University of New York, Binghampton, New York, 1973, pp. 161-179.

HAYDEN, B., et a1., "Systematic Variations in Inshore Bathymetry," Technical Report No. 10, Department of Environmental Science, University of Virginia, Charlottesville, Va., Jan. 1975.

JOHnSON, D.W., Shore Processes and ShoreZine Development, 1st ed., John Wiley \& Sons, Inc., New York, 1919.

PRICE, W.A., "Correlation of Shoreline Type With Offshore Conditions in the Gulf of Mexico," Second Coastal Geography Conference, National Academy of Sciences, National Research Counci1, 1954, pp. 11-30.

RESIO, D., et al., "Systematic Variations in Offshore Bathymetry," Technical Report No. 9, Department of Environmental Sciences, University of Virginia, Charlottesville, Va., 1974.

SHEPARD, F.P., Submarine Geology, Harper and Row, New York, 1963.

SHERIDAN, R.E., DILL, C.E., and KRAFT, J.C., "Holocene Sedimentary Environment of the Atlantic Inner Shelf off Delaware," The Geological Society of America Bulletin, Vo1. 85, No. 8, Aug. 1974, pp. 1319-1328.

U.S. ARMY, CORPS OF ENGINEERS, COASTAL ENGINEERING RESEARCH CENTER, Shore Protection Manual, 3d ed., Vols. I, II, and III, Stock No. 008-022-00113-1, U.S. Government Printing Office, Washington, D.C., $1977,1,262 \mathrm{pp}$. 



\section{APPENDIX A}

\section{PROFILE LOCATIONS}

Profile data were obtained from the listed NOS 1200 series charts. Profile location is described from symbols and cultural features represented on the charts. Profile azimuth is the profile line direction referenced to true north, and oriented from the coast in a seaward direction. The latitude and longitude is the origin of the profile line at the MLW shoreline. 


\begin{tabular}{|c|c|c|c|c|c|}
\hline $\begin{array}{l}\text { Profile } \\
\text { code }\end{array}$ & $\begin{array}{l}\text { Profile } \\
\text { location }\end{array}$ & $\begin{array}{c}\text { Chart } \\
\text { No. }\end{array}$ & $\begin{array}{l}\text { Profile } \\
\text { azimuth }\end{array}$ & Latitude & Longitude \\
\hline 1 & $\begin{array}{l}\text { Cupula - Quogue Beach, } \\
\text { Long Island, New York }\end{array}$ & 1214 & $160^{\circ}$ & $40^{\circ} 48.35^{\prime}$ & $72^{\circ} 35.96^{\prime}$ \\
\hline 2 & $\begin{array}{l}\text { Toms River Coast Guard Tower } \\
\text { No. 109, New Jersey }\end{array}$ & 1216 & $95^{\circ}$ & $39^{\circ} 56.11^{\prime}$ & $74^{\circ} 04.33^{\prime}$ \\
\hline 3 & $\begin{array}{l}\text { Ventnor City Pier, } \\
\text { New Jersey }\end{array}$ & 1217 & $160^{\circ}$ & $39^{\circ} 20.22^{\prime}$ & $74^{\circ} 28.69^{\prime}$ \\
\hline 4 & $\begin{array}{l}\text { Two-Mile Beach, } \\
\text { New Jersey }\end{array}$ & 1219 & $132^{\circ}$ & $38^{\circ} 58.05^{\prime}$ & $74^{\circ} 49.48^{\prime}$ \\
\hline 5 & $\begin{array}{l}\text { Bethany Beach Tower, } \\
\text { Delaware }\end{array}$ & 1219 & $90^{\circ}$ & $38^{\circ} 31.59^{\prime}$ & $75^{\circ} 03.21^{\prime}$ \\
\hline 6 & $\begin{array}{l}\text { Assateague Island, } \\
\text { Maryland }\end{array}$ & 1220 & $110^{\circ}$ & $38^{\circ} 13.07^{\prime}$ & $75^{\circ} 08.61^{\prime}$ \\
\hline 7 & $\begin{array}{l}\text { Metomkin Island, } \\
\text { Virginia }\end{array}$ & 1221 & $125^{\circ}$ & $37^{\circ} 44.40^{\prime}$ & $75^{\circ} 33.06^{\prime}$ \\
\hline 8 & $\begin{array}{l}\text { Smith Island, } \\
\text { Virginia }\end{array}$ & 1222 & $134^{\circ}$ & $37^{\circ} 09.81^{\prime}$ & $75^{\circ} 50.48^{\prime}$ \\
\hline 9 & $\begin{array}{l}\text { Virginia Beach, } \\
\text { Virginia }\end{array}$ & 1227 & $77^{\circ}$ & $36^{\circ} 49.18^{\prime}$ & $75^{\circ} 58.06^{\prime}$ \\
\hline 10 & $\begin{array}{l}\text { South of Fresh Pond } \\
\text { Hill, North Carolina }\end{array}$ & 1227 & $80^{\circ}$ & $36^{\circ} 29.38^{\prime}$ & $75^{\circ} 51.34^{\prime}$ \\
\hline 11 & $\begin{array}{l}\text { Nags Head, } \\
\text { North Carolina }\end{array}$ & 1229 & $65^{\circ}$ & $35^{\circ} 54.60^{\prime}$ & $75^{\circ} 35.82^{\prime}$ \\
\hline 12 & $\begin{array}{l}\text { Wreck-Hatteras Island - Gull } \\
\text { Island Bay, North Carolina }\end{array}$ & 1232 & $95^{\circ}$ & $35^{\circ} 28.17^{\prime}$ & $75^{\circ} 28.86^{\prime}$ \\
\hline 13 & $\begin{array}{l}\text { Chimney, Core Banks, } \\
\text { North Carolina }\end{array}$ & 1233 & $130^{\circ}$ & $34^{\circ} 48.03^{\prime}$ & $76^{\circ} 22.28^{\prime}$ \\
\hline 14 & $\begin{array}{l}\text { Salter Path, Bogue } \\
\text { Banks, North Carolina }\end{array}$ & 1234 & $170^{\circ}$ & $34^{\circ} 41.03^{\prime}$ & $76^{\circ} 53.89^{\prime}$ \\
\hline 15 & $\begin{array}{l}\text { Topsail Beach - Surf City, } \\
\text { North Carolina }\end{array}$ & 1235 & $140^{\circ}$ & $34^{\circ} 24.43^{\prime}$ & $77^{\circ} 34.41^{\prime}$ \\
\hline 16 & $\begin{array}{l}\text { Masonboro Sound, } \\
\text { North Carolina }\end{array}$ & 1235 & $113^{\circ}$ & $34^{\circ} 05.45^{\prime}$ & $77^{\circ} 51.84^{\prime}$ \\
\hline
\end{tabular}




\begin{tabular}{|c|c|c|c|c|c|}
\hline $\begin{array}{l}\text { Profile } \\
\text { code }\end{array}$ & $\begin{array}{l}\text { Profile } \\
\text { location }\end{array}$ & $\begin{array}{c}\text { Chart } \\
\text { No. }\end{array}$ & $\begin{array}{l}\text { Profile } \\
\text { azimuth }\end{array}$ & Latitude & Longitude \\
\hline 17 & $\begin{array}{l}\text { South Pier, Myrtle Beach, } \\
\text { South Carolina }\end{array}$ & 1237 & $135^{\circ}$ & $33^{\circ} 41.03^{\prime}$ & $78^{\circ} 53.20^{\prime}$ \\
\hline 18 & $\begin{array}{l}\text { Midway Inlet, } \\
\text { South Carolina }\end{array}$ & 1237 & $118^{\circ}$ & $33^{\circ} 26.13^{\prime}$ & $79^{\circ} 07.06^{\prime}$ \\
\hline 19 & $\begin{array}{l}\text { Kiawah Island, } \\
\text { South Carolina }\end{array}$ & 1239 & $166^{\circ}$ & $32^{\circ} 36.13^{\prime}$ & $80^{\circ} 04.90^{\prime}$ \\
\hline 20 & $\begin{array}{l}\text { Skul1 Inlet, } \\
\text { South Carolina }\end{array}$ & 1240 & $153^{\circ}$ & $32^{\circ} 18.01^{\prime}$ & $80^{\circ} 30.96^{\prime}$ \\
\hline 21 & $\begin{array}{l}\text { St. Catherines Island, } \\
\text { Georgia }\end{array}$ & 1241 & $105^{\circ}$ & $31^{\circ} 38.04^{\prime}$ & $81^{\circ} 08.12^{\prime}$ \\
\hline 22 & $\begin{array}{l}\text { Pier, Jacksonville Beach, } \\
\text { Florida }\end{array}$ & 1243 & $80^{\circ}$ & $30^{\circ} 17.00^{\prime}$ & $81^{\circ} 23.30^{\prime}$ \\
\hline 23 & $\begin{array}{l}\text { Pier, Flagler Beach, } \\
\text { Florida }\end{array}$ & 1244 & $75^{\circ}$ & $29^{\circ} 28.79^{\prime}$ & $81^{\circ} 07.70^{\prime}$ \\
\hline 24 & E1dora Beach, & 1245 & $60^{\circ}$ & $28^{\circ} 53.30^{\prime}$ & $80^{\circ} 47.73^{\prime}$ \\
\hline
\end{tabular}

25 Eight miles north of

$1246 \quad 65^{\circ} \quad 27^{\circ} 59.24 \quad 80^{\circ} 31.07^{\prime}$

Sebastian Inlet, Florida

26 East of White City Station, $124765^{\circ} 27^{\circ} 23.00^{\prime} 80^{\circ} 15.31^{\prime}$ near Ft. Pierce, Florida

27 Manasota Key, Florida

$1256240^{\circ} \quad 27^{\circ} 00.32^{\prime} \quad 82^{\circ} 24.62^{\prime}$

28 Longboat Key,

Florida

29 Aripeka, Florida

$1256 \quad 233^{\circ} \quad 27^{\circ} 22.84^{\prime} \quad 82^{\circ} 38.26^{\prime}$

$1258285^{\circ} \quad 28^{\circ} 26.30^{\prime} \quad 82^{\circ} 40.68^{\prime}$

30 Spring Warrior, Florida

$1260,1 \quad 215^{\circ} \quad 29^{\circ} 55.88^{\prime} \quad 83^{\circ} 42.29^{\prime}$

31 Spring Warrior, Florida

$1260215^{\circ} \quad 29^{\circ} 55.38^{\prime} \quad 83^{\circ} 41.40^{\prime}$

32 Bulkhead Point, St. George Island, Florida

$1262 \quad 151^{\circ} \quad 29^{\circ} 38.81^{\prime} \quad 84^{\circ} 53.69^{\prime}$ 


\begin{tabular}{|c|c|c|c|c|c|}
\hline $\begin{array}{l}\text { Profile } \\
\text { code }\end{array}$ & $\begin{array}{l}\text { Profile } \\
\text { location }\end{array}$ & $\begin{array}{l}\text { Chart } \\
\text { No. }\end{array}$ & $\begin{array}{l}\text { Profile } \\
\text { azimuth }\end{array}$ & Latitude & Longitude \\
\hline 33 & $\begin{array}{l}\text { Topsail Bluff - Grayton } \\
\text { Beach, Florida }\end{array}$ & 1264 & $195^{\circ}$ & $30^{\circ} 21.21^{\prime}$ & $86^{\circ} 15.49^{\prime}$ \\
\hline 34 & $\begin{array}{l}\text { Santa Rosa Island, } \\
\text { Florida }\end{array}$ & 1265 & $165^{\circ}$ & $30^{\circ} 22.30^{\prime}$ & $86^{\circ} 54.57^{\prime}$ \\
\hline 35 & $\begin{array}{l}\text { Horn Island, } \\
\text { Mississippi }\end{array}$ & 1267 & $190^{\circ}$ & $30^{\circ} 13.74^{\prime}$ & $88^{\circ} 40.00^{\prime}$ \\
\hline 36 & $\begin{array}{l}\text { Curlew Island, } \\
\text { Louisiana }\end{array}$ & 1270 & $136^{\circ}$ & $29^{\circ} 37.30^{\prime}$ & $88^{\circ} 59.02^{\prime}$ \\
\hline 37 & $\begin{array}{l}\text { Caminada Pass, } \\
\text { Louisiana }\end{array}$ & 1273 & $142^{\circ}$ & $29^{\circ} 05.28^{\prime}$ & $90^{\circ} 06.50^{\prime}$ \\
\hline 38 & $\begin{array}{l}\text { East Timbalier Island, } \\
\text { Louisiana }\end{array}$ & 1274 & $164^{\circ}$ & $29^{\circ} 03.45^{\prime}$ & $90^{\circ} 20.42^{\prime}$ \\
\hline 39 & $\begin{array}{l}\text { Point Au Fer Island, } \\
\text { Louisiana }\end{array}$ & 1276 & $219^{\circ}$ & $29^{\circ} 15.32^{\prime}$ & $91^{\circ} 17.50^{\prime}$ \\
\hline 40 & $\begin{array}{l}\text { Big Constance Lake, } \\
\text { Louisiana }\end{array}$ & 1278 & $190^{\circ}$ & $29^{\circ} 35.28^{\prime}$ & $92^{\circ} 39.25^{\prime}$ \\
\hline 41 & $\begin{array}{l}\text { Mermentau River Mouth, } \\
\text { Louisiana }\end{array}$ & 1278 & $193^{\circ}$ & $29^{\circ} 45.80^{\prime}$ & $93^{\circ} 09.19^{\prime}$ \\
\hline 42 & $\begin{array}{l}\text { Pier PA, near High Island, } \\
\text { Texas }\end{array}$ & 1280 & $160^{\circ}$ & $29^{\circ} 32.24^{\prime}$ & $94^{\circ} 25.00^{\prime}$ \\
\hline 43 & $\begin{array}{l}\text { Pa1m Beach, Galveston } \\
\text { Island, Texas }\end{array}$ & 1282 & $150^{\circ}$ & $29^{\circ} 11.58^{\prime}$ & $94^{\circ} 57.00^{\prime}$ \\
\hline 44 & $\begin{array}{l}\text { Cedar Lakes, } \\
\text { Texas }\end{array}$ & 1283 & $148^{\circ}$ & $28^{\circ} 47.46^{\prime}$ & $95^{\circ} 33.90^{\prime}$ \\
\hline 45 & $\begin{array}{l}\text { Matagorda Peninsula, } \\
\text { Texas }\end{array}$ & 1284 & $155^{\circ}$ & $28^{\circ} 33.71^{\prime}$ & $96^{\circ} 03.92^{\prime}$ \\
\hline 46 & $\begin{array}{l}\text { Matagorda Island, } \\
\text { Texas }\end{array}$ & 1285 & $142^{\circ}$ & $28^{\circ} 09.80^{\prime}$ & $96^{\circ} 43.25^{\prime}$ \\
\hline 47 & $\begin{array}{l}\text { Mustang Island - Padre } \\
\text { Island, Texas }\end{array}$ & 1286 & $115^{\circ}$ & $27^{\circ} 34.86^{\prime}$ & $97^{\circ} 13.18^{\prime}$ \\
\hline 48 & $\begin{array}{l}\text { E1 Toro Island - Padre } \\
\text { Island, Texas }\end{array}$ & 1287 & $85^{\circ}$ & $26^{\circ} 56.61^{\prime}$ & $97^{\circ} 22.41^{\prime}$ \\
\hline 49 & $\begin{array}{l}\text { Near La Punta Larga, } \\
\text { Padre Island, Texas }\end{array}$ & 1288 & $80^{\circ}$ & $26^{\circ} 17.43^{\prime}$ & $97^{\circ} 11.48^{\prime}$ \\
\hline
\end{tabular}


APPENDIX B

DATA COLLECTION SCHEME

Depth measurements were made at 30 stations per profile line and along 9 profile lines at each locality. The station distances (in meters from shore) are given along the vertical axis. The profile origin in Appendix A is the MLW shoreline on profile line 5 in each group of 9 . 


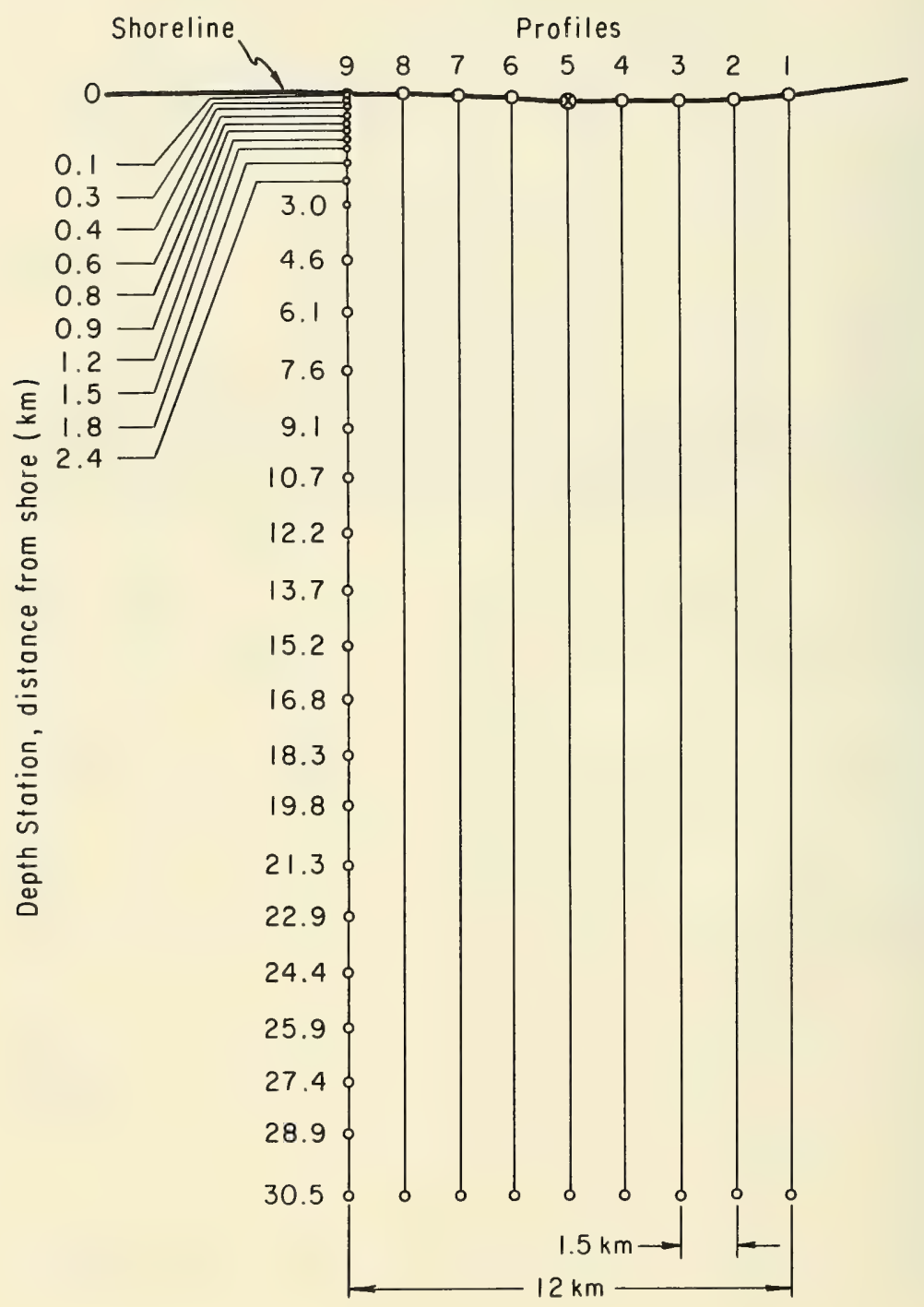




\section{APPENDIX C \\ INNER CONTINENTAL SHELF PROFILES}

Inner Continental Shelf profiles are given for 49 localities located in Figure 1 and Appendix A. Solid-line profile segments were obtained by averaging nine profile lines (App. B) at each locality. Solid circles are depth-distance points calculated using the procedure presented in Appendix D. 


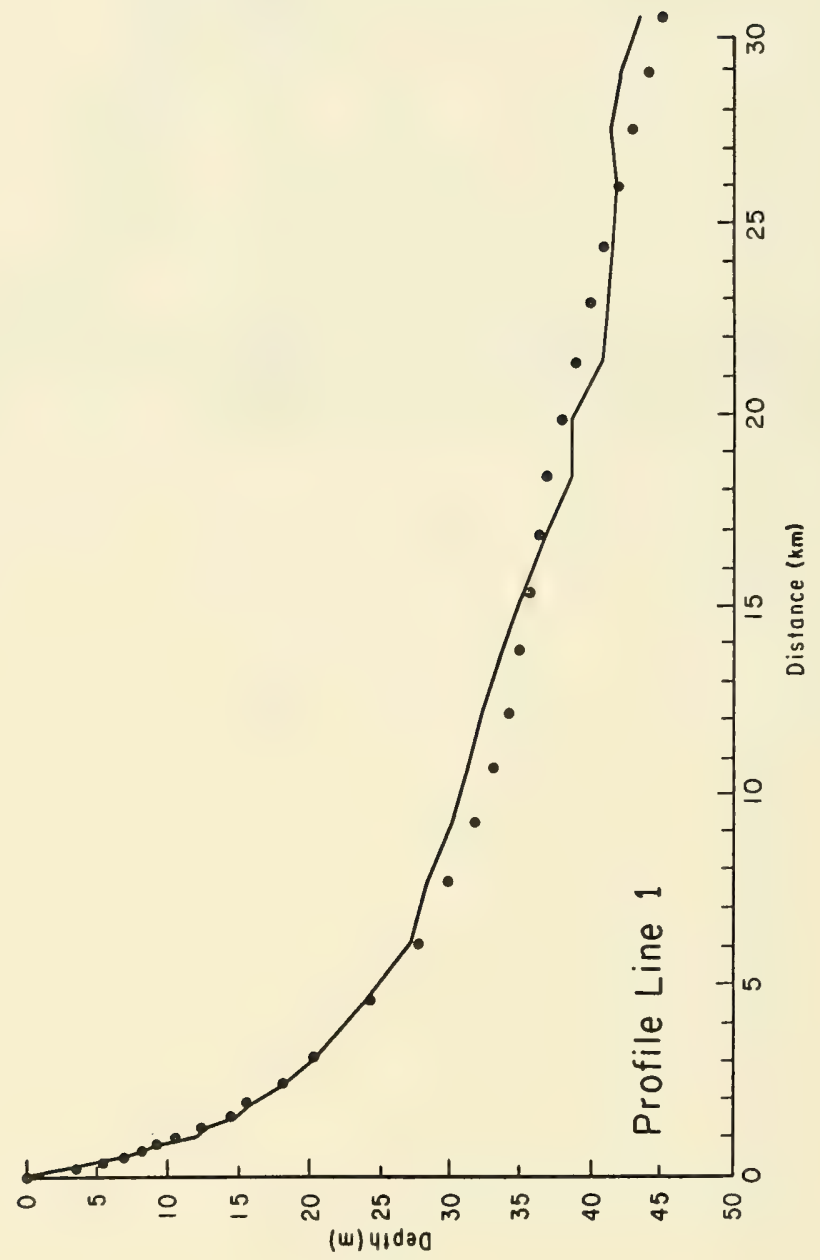




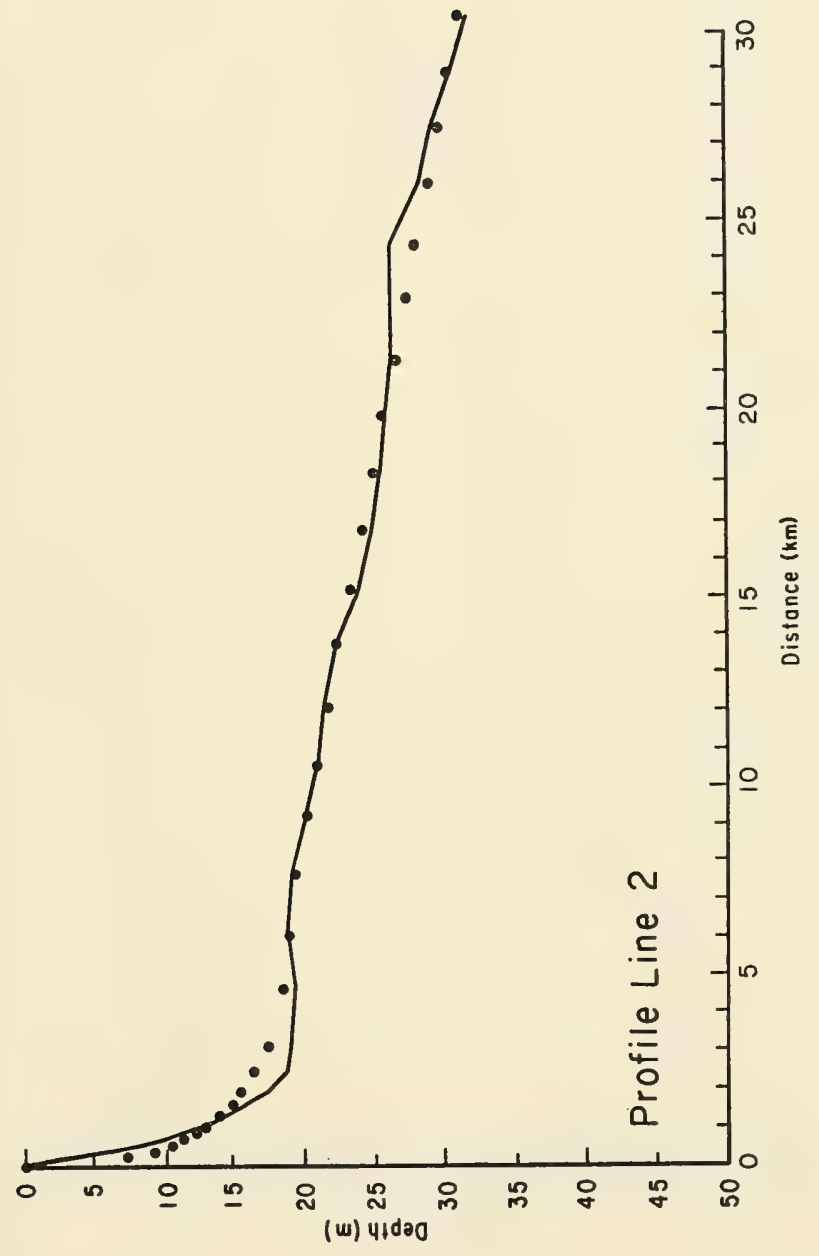




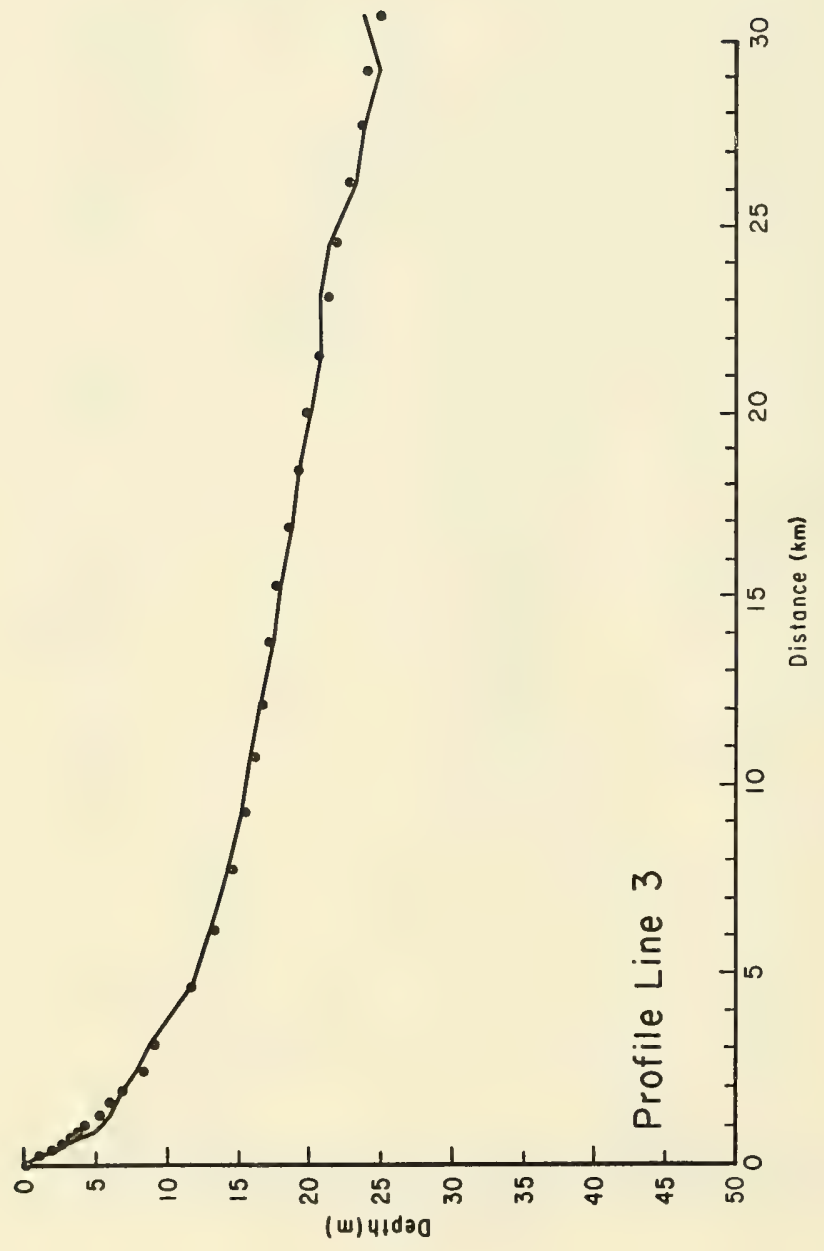




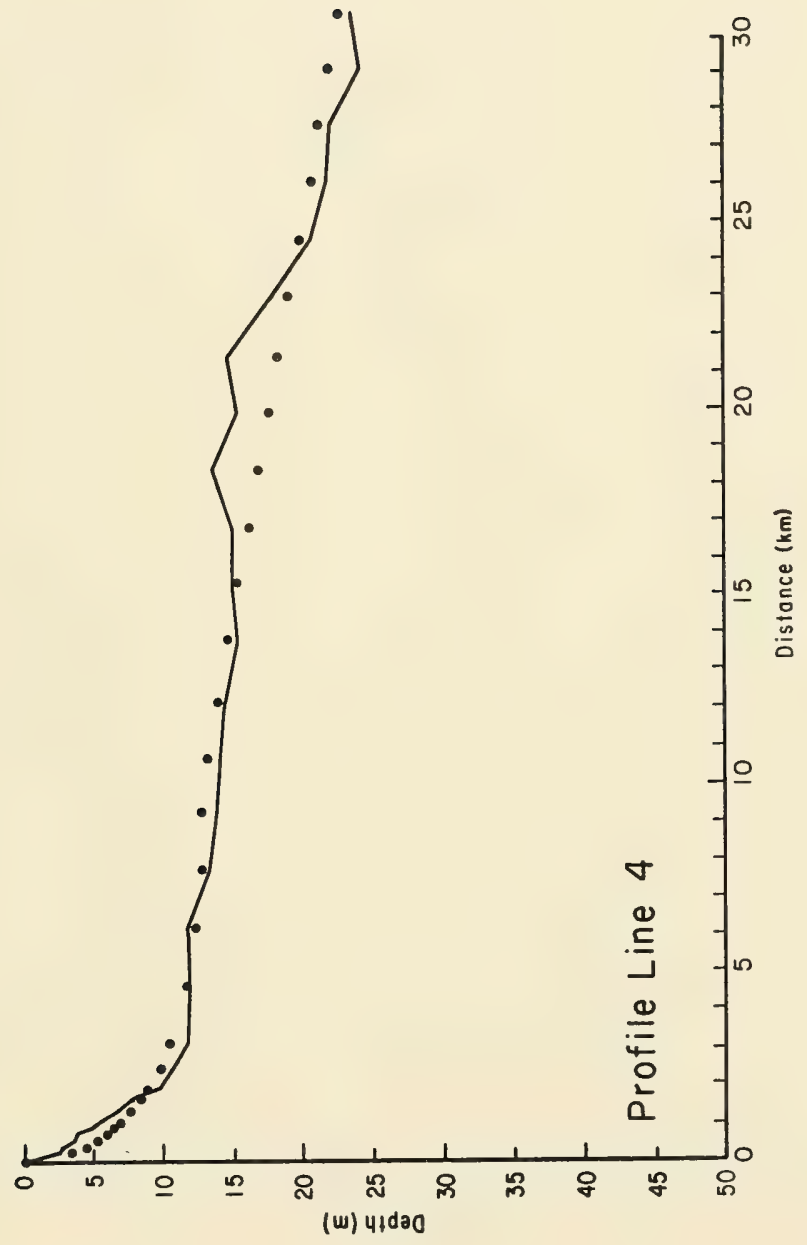




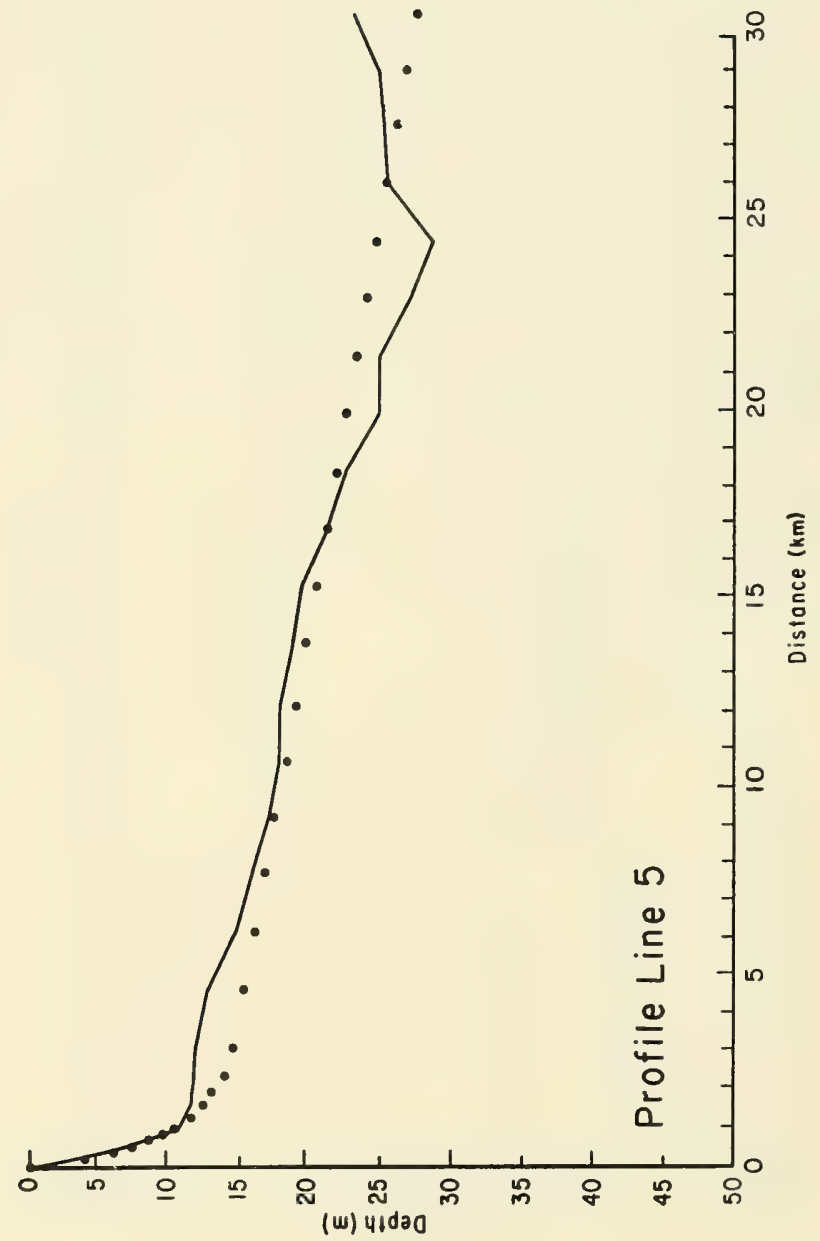




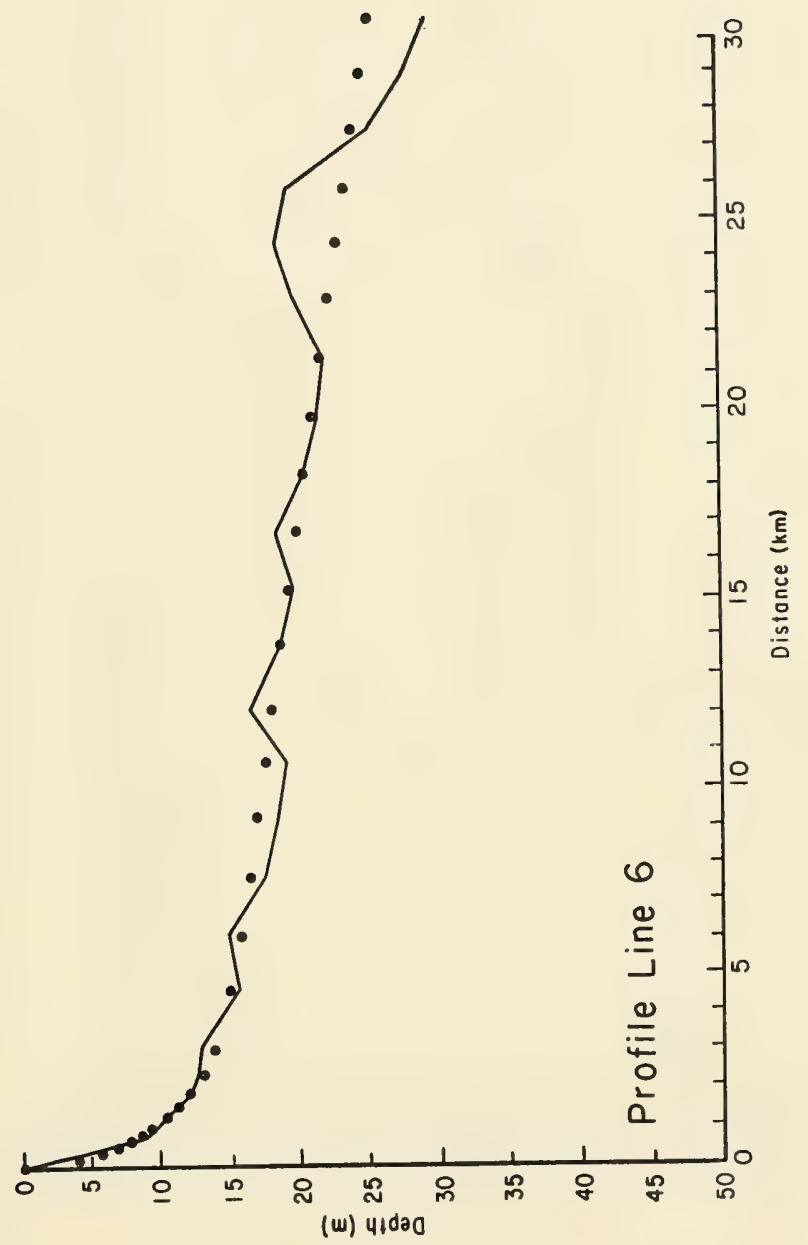




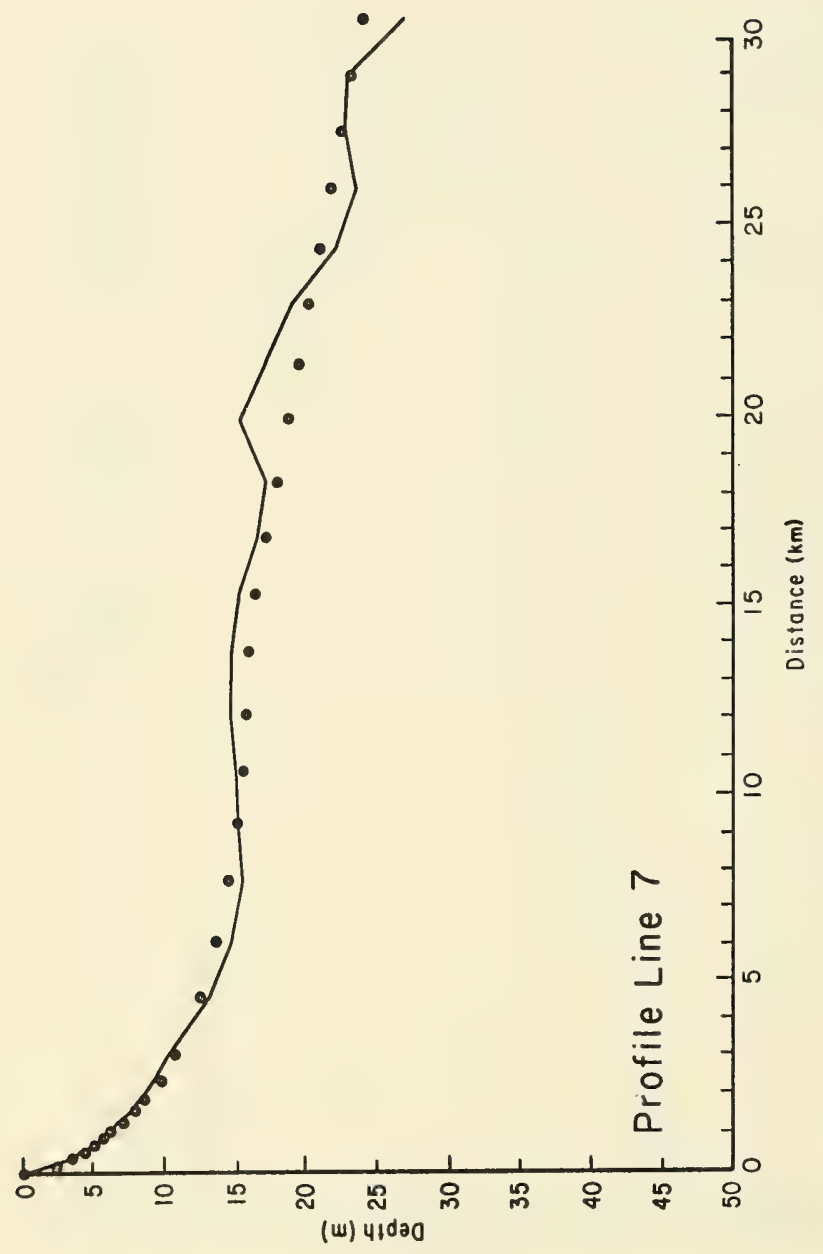




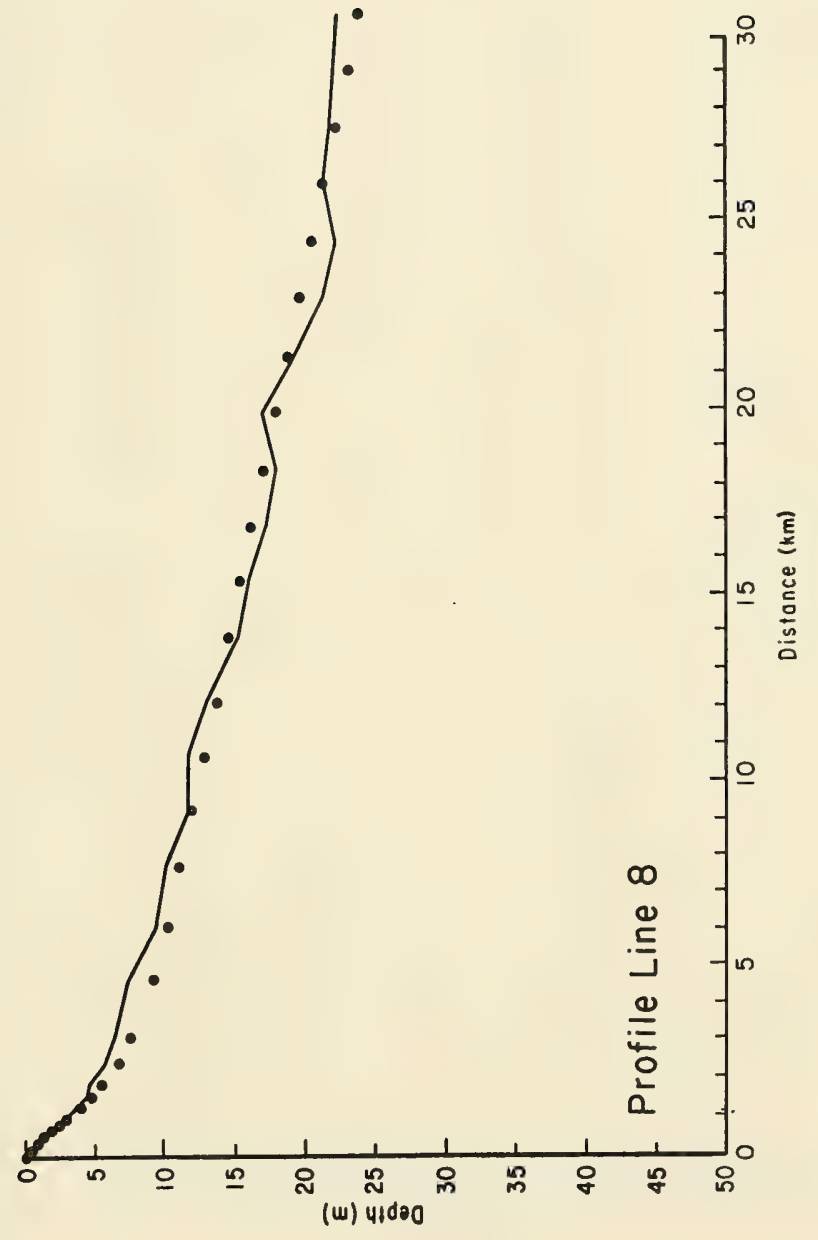




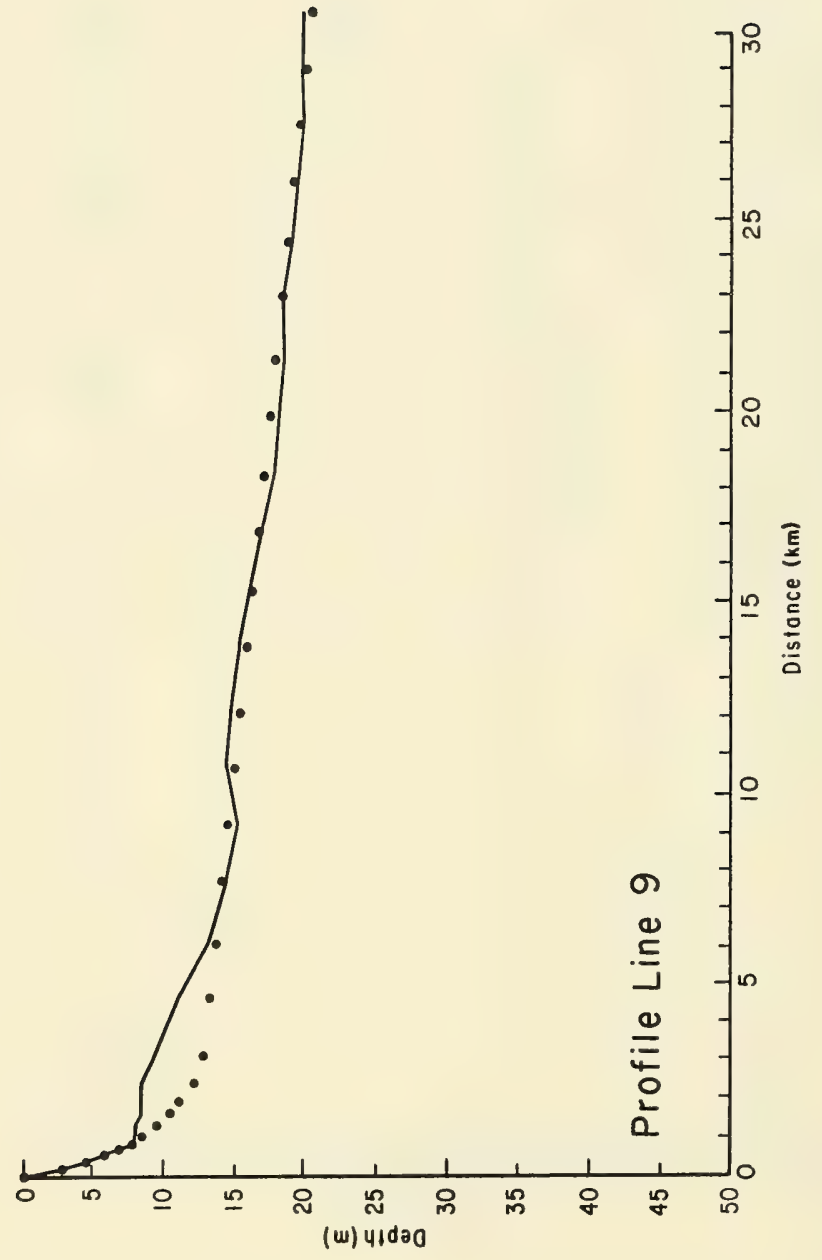




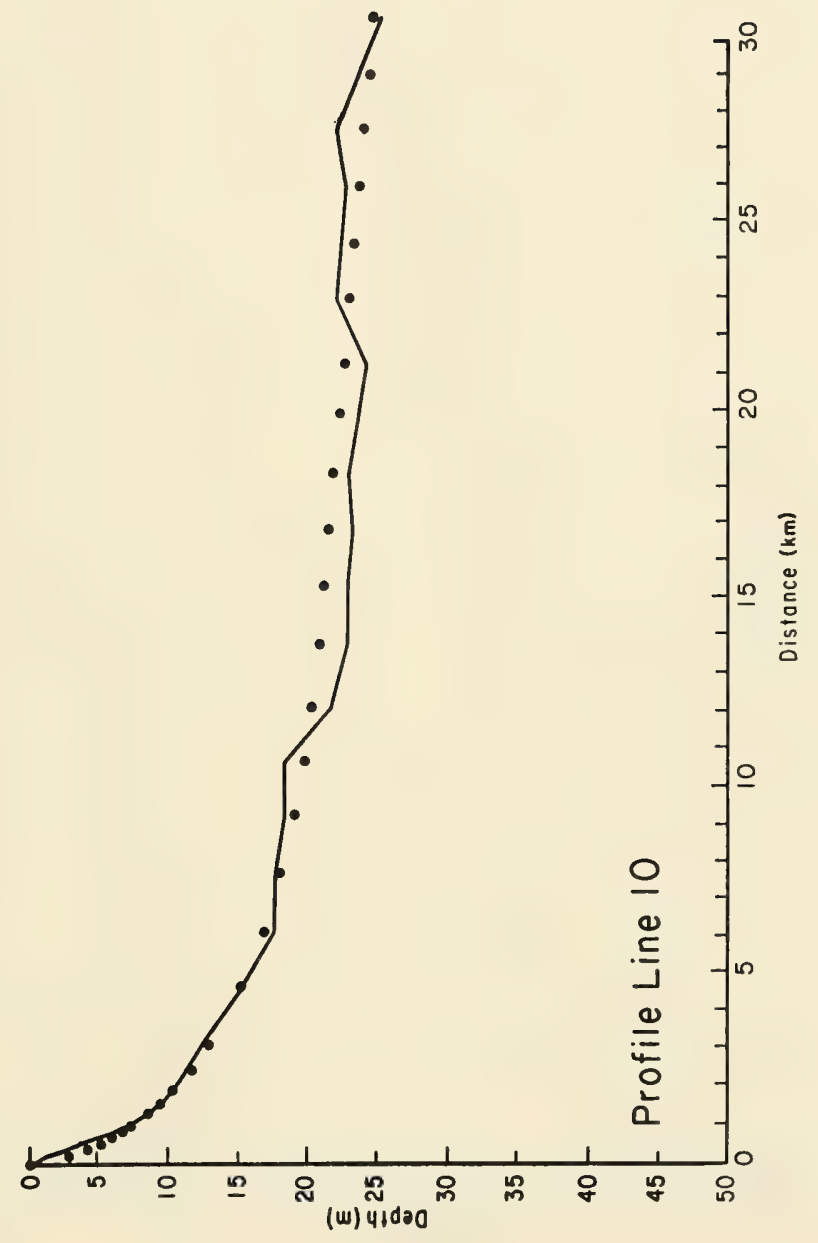




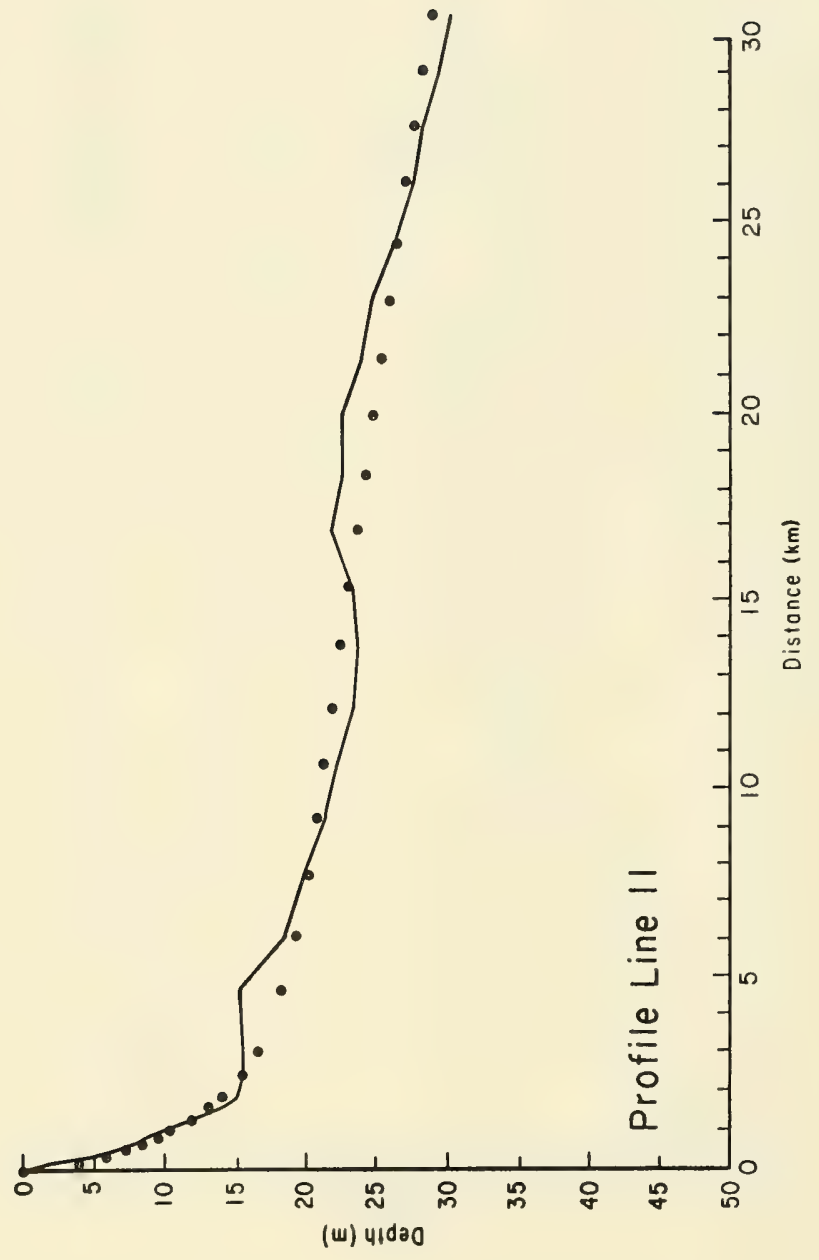




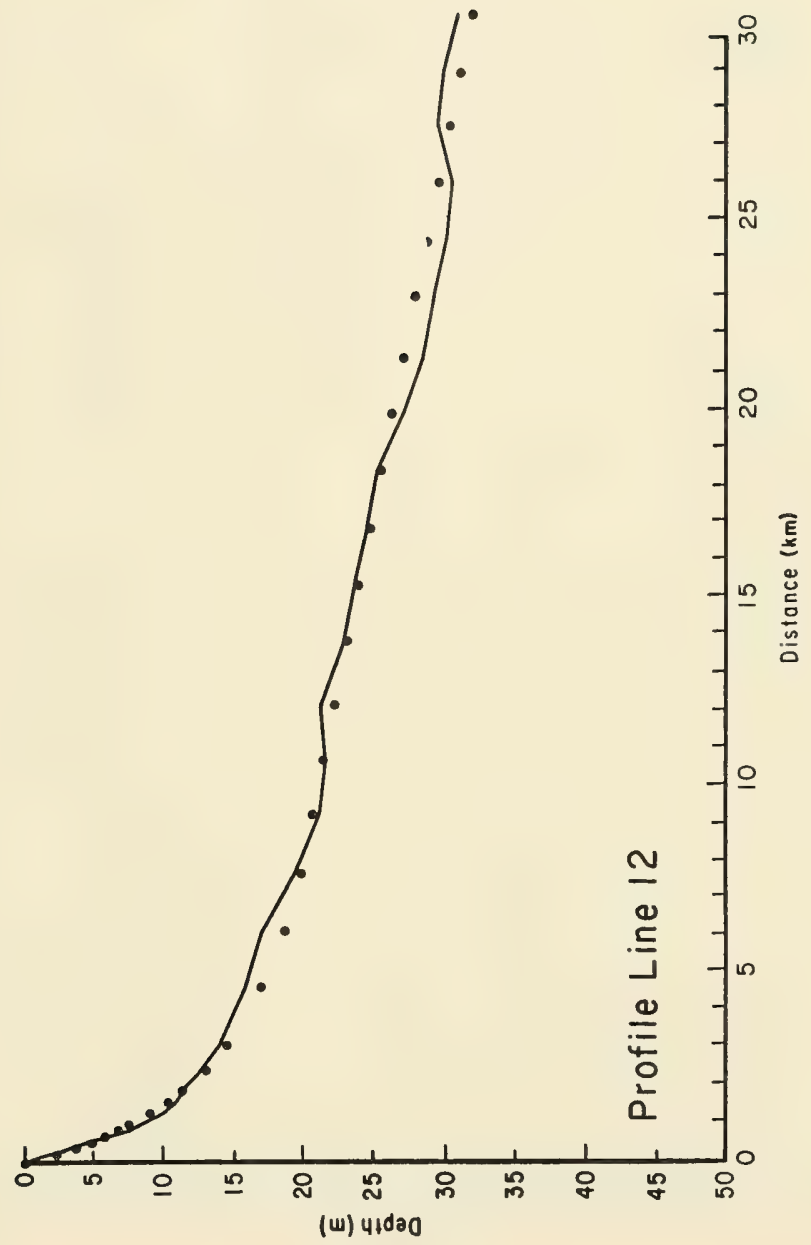




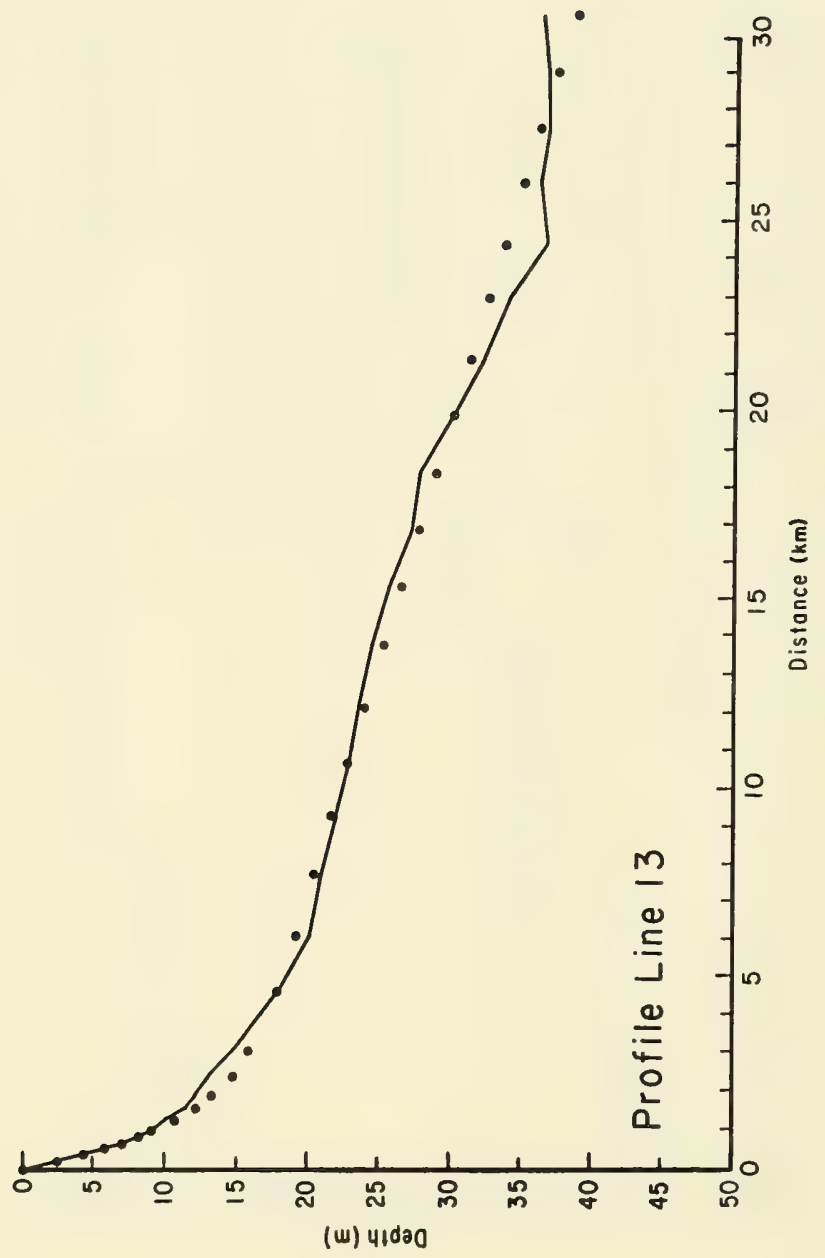




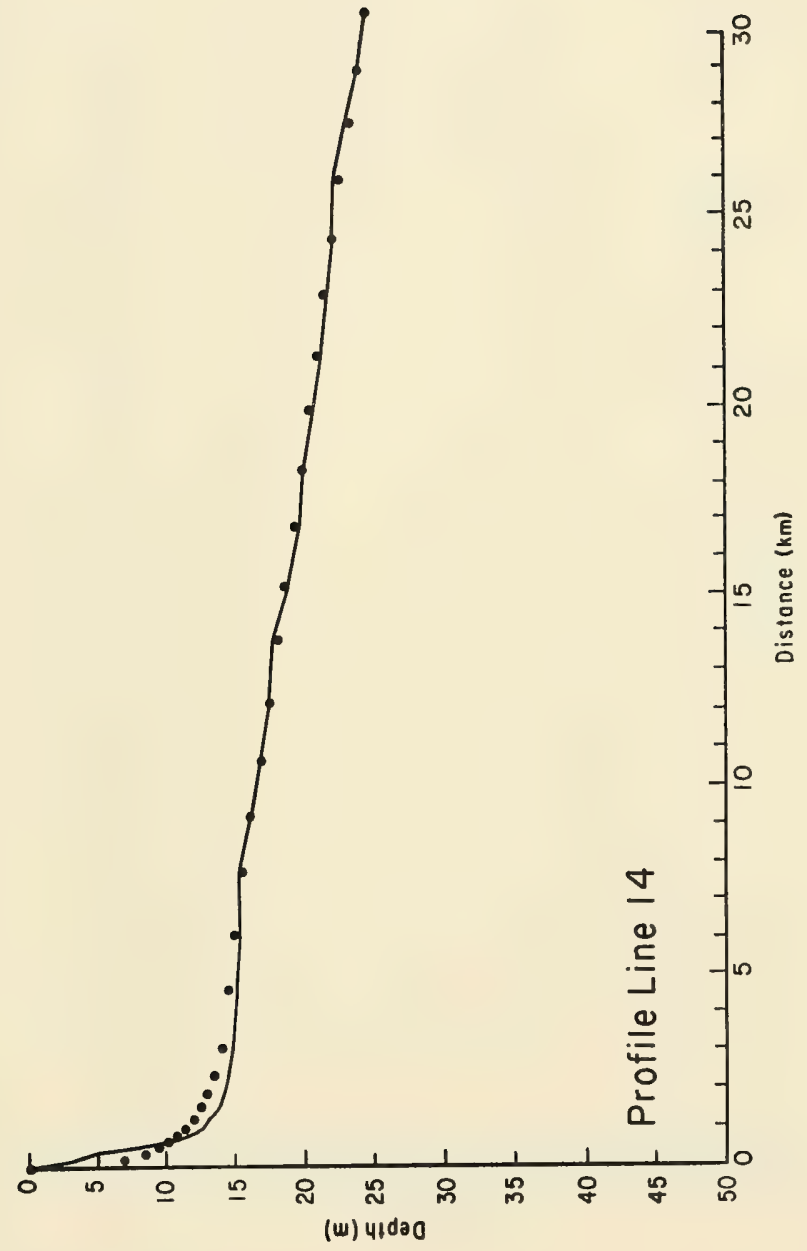




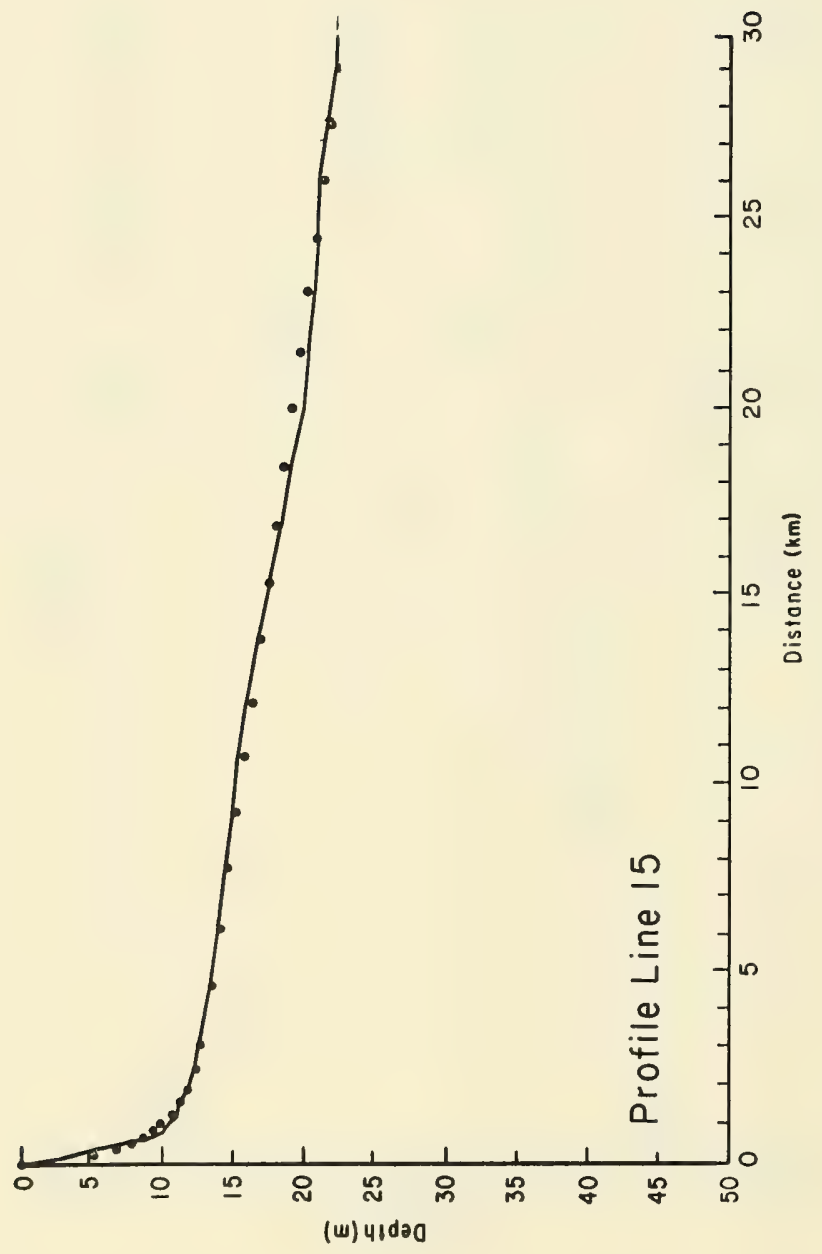




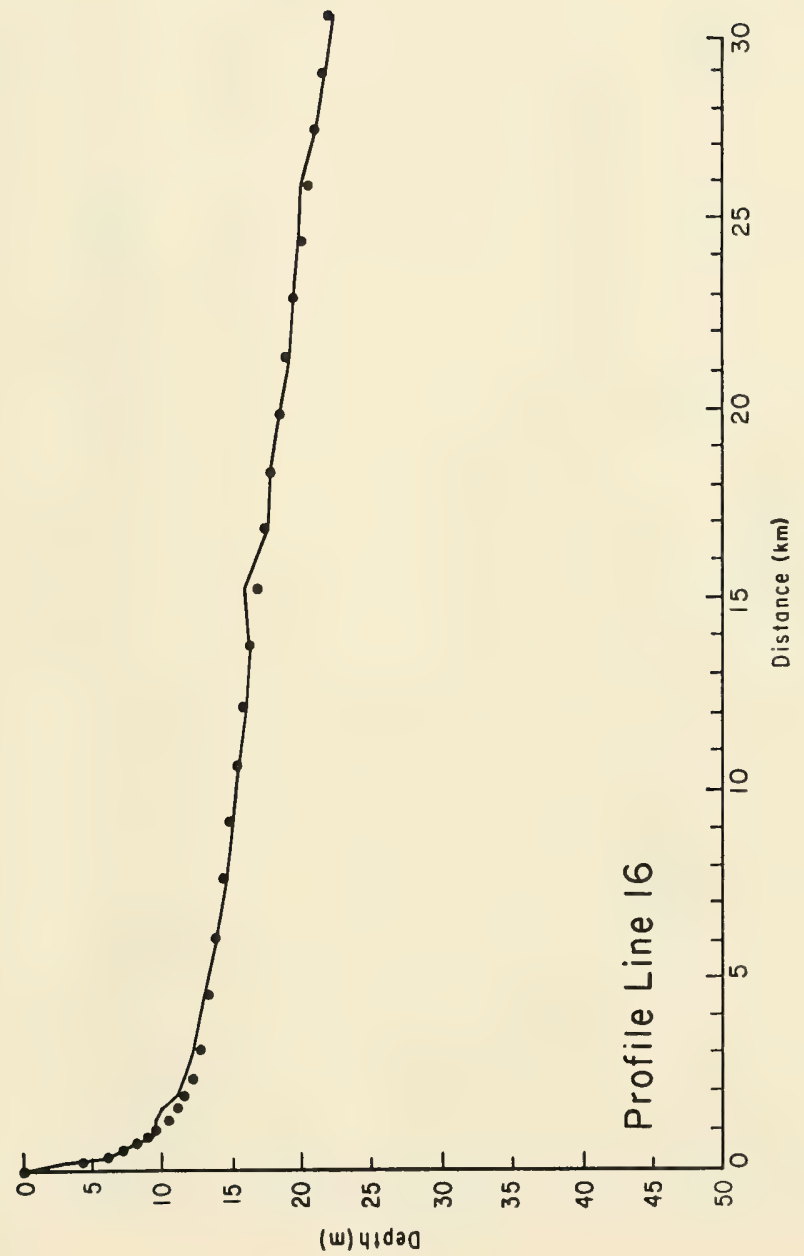




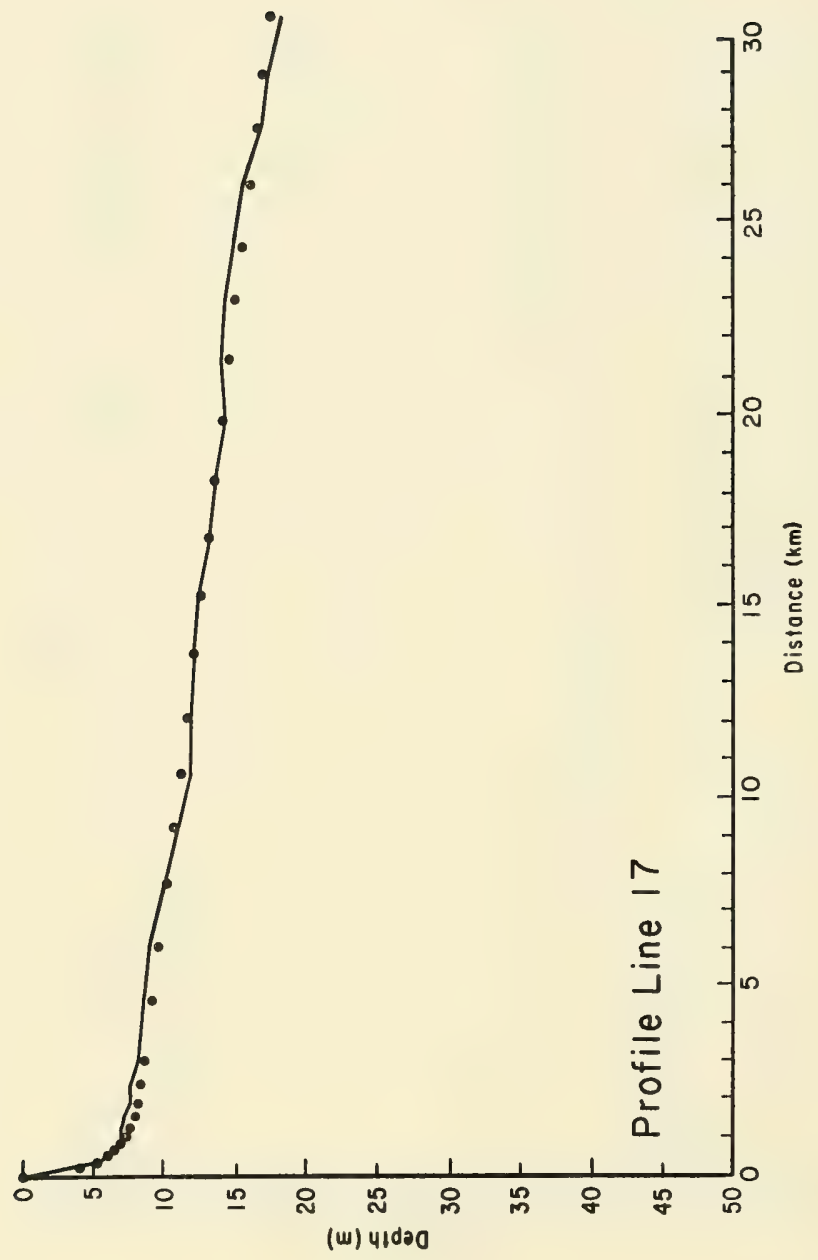




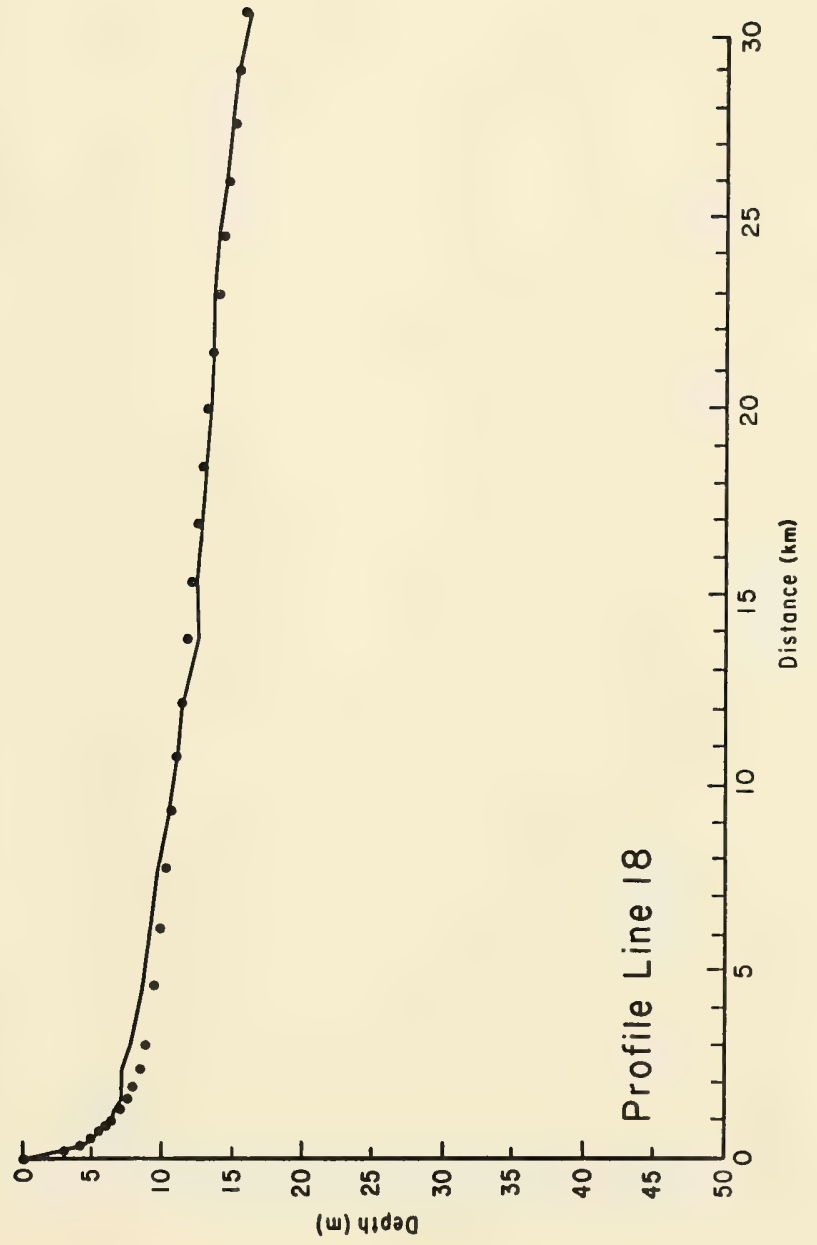




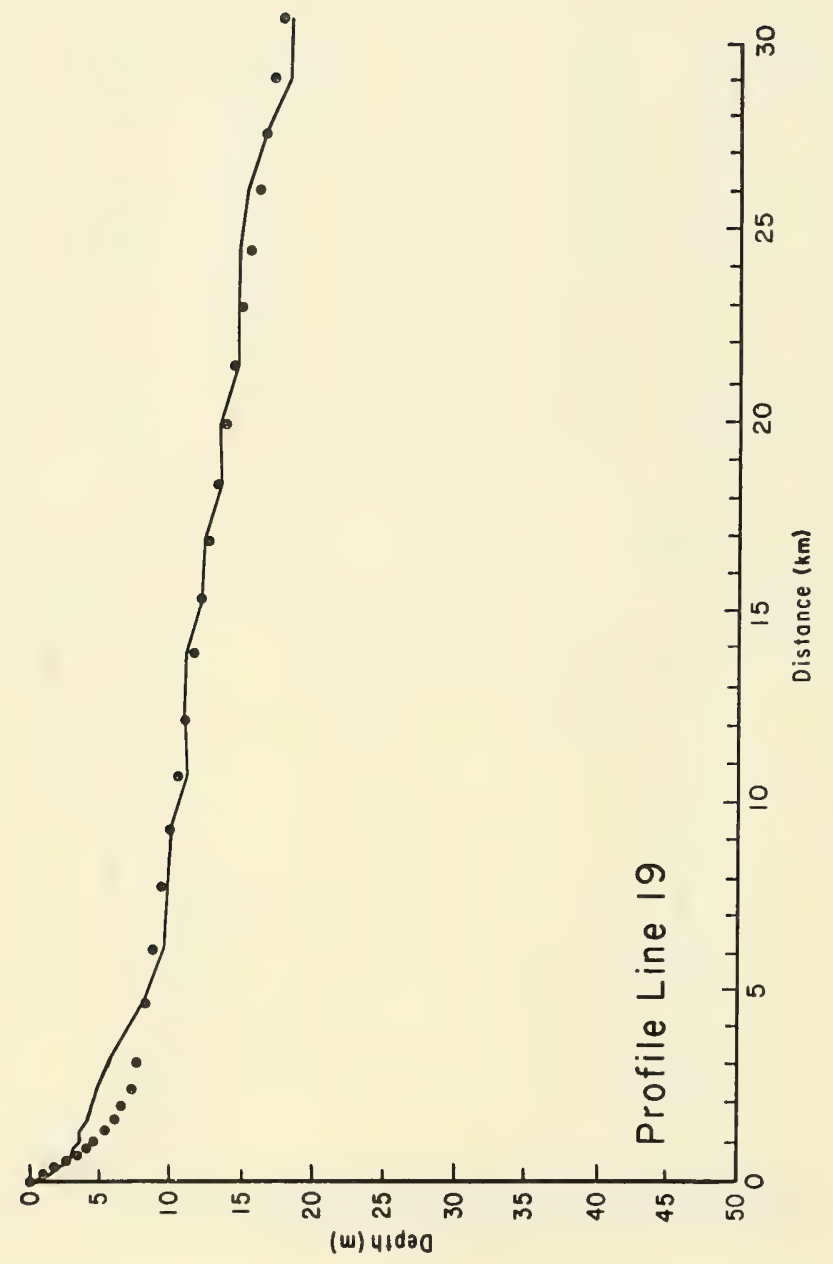




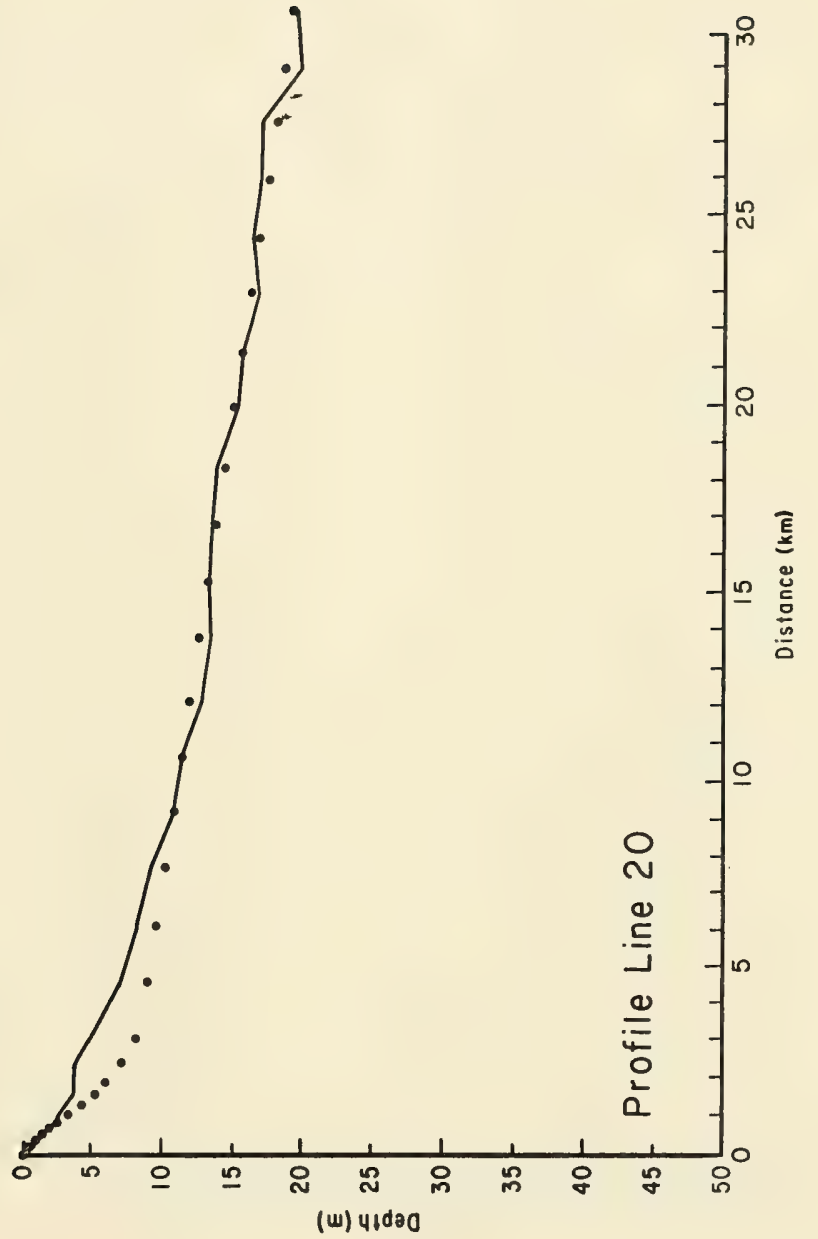




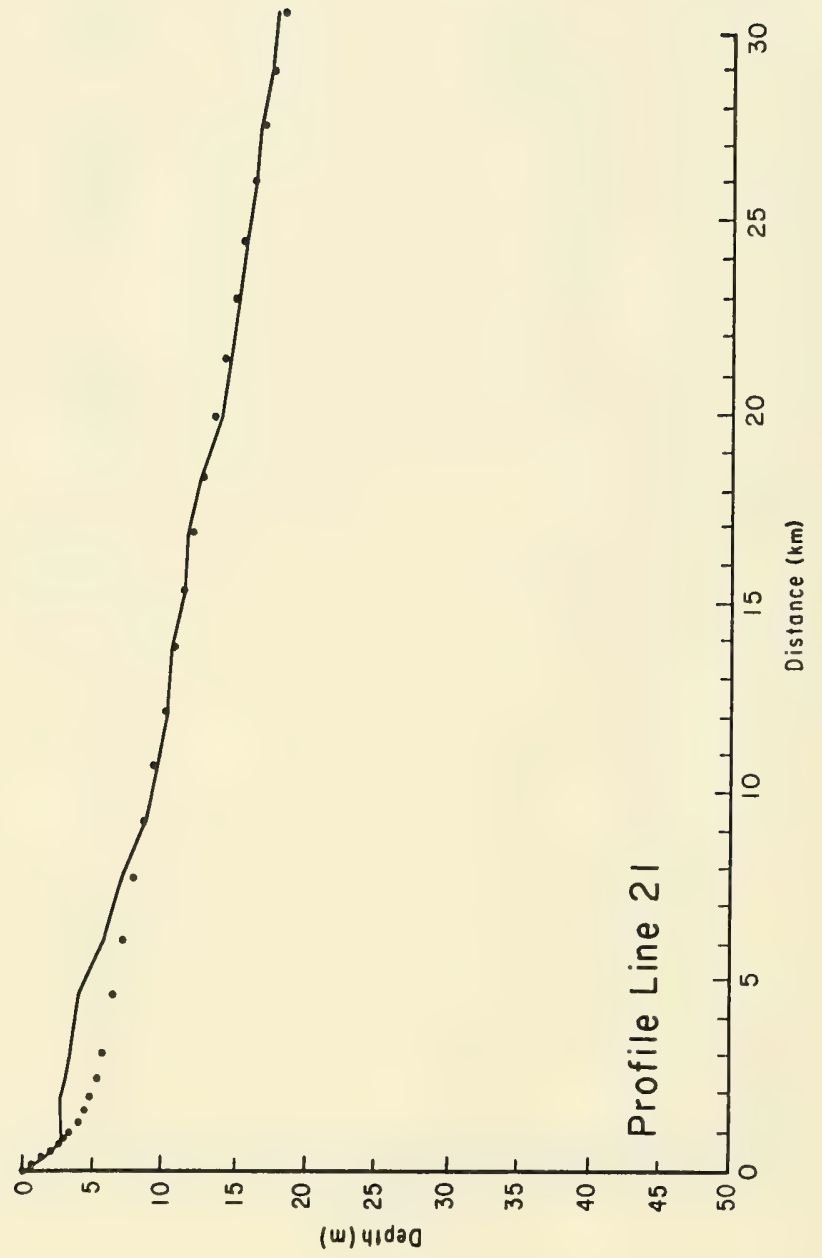




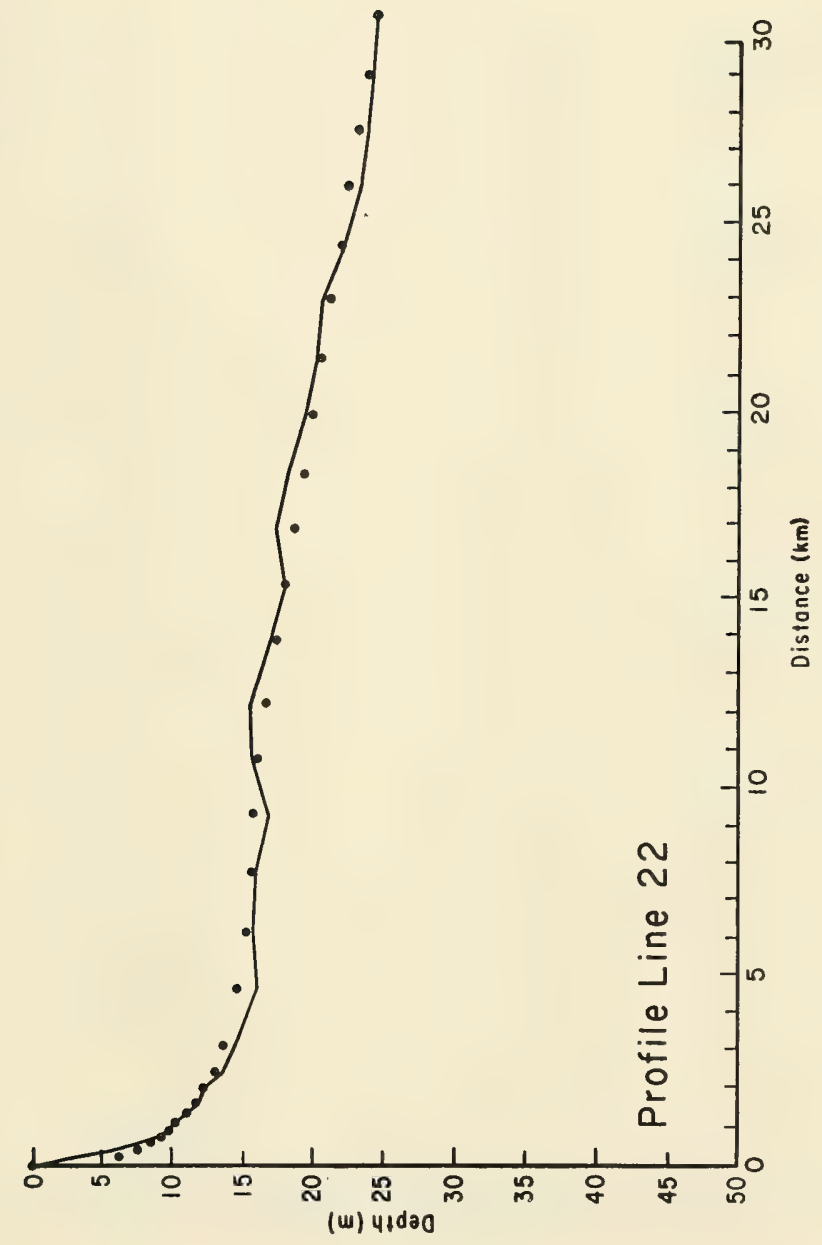




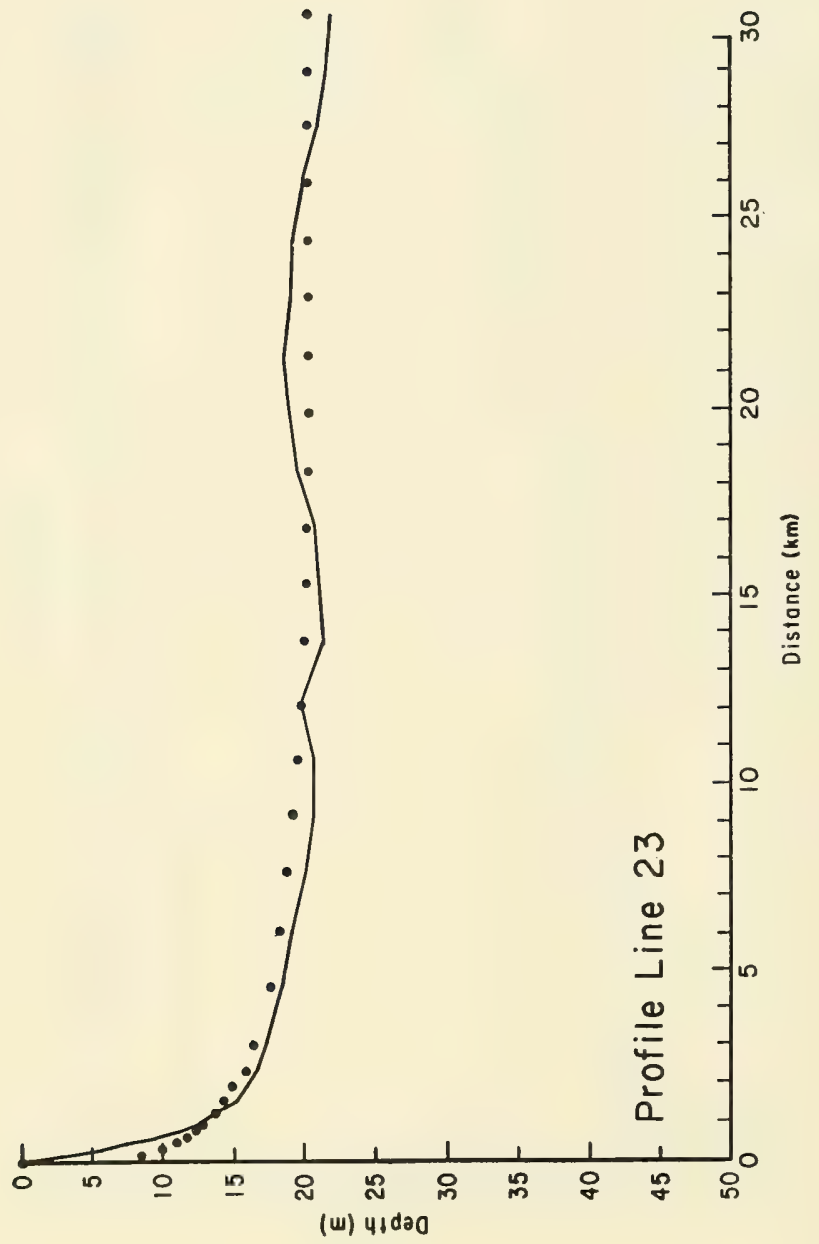




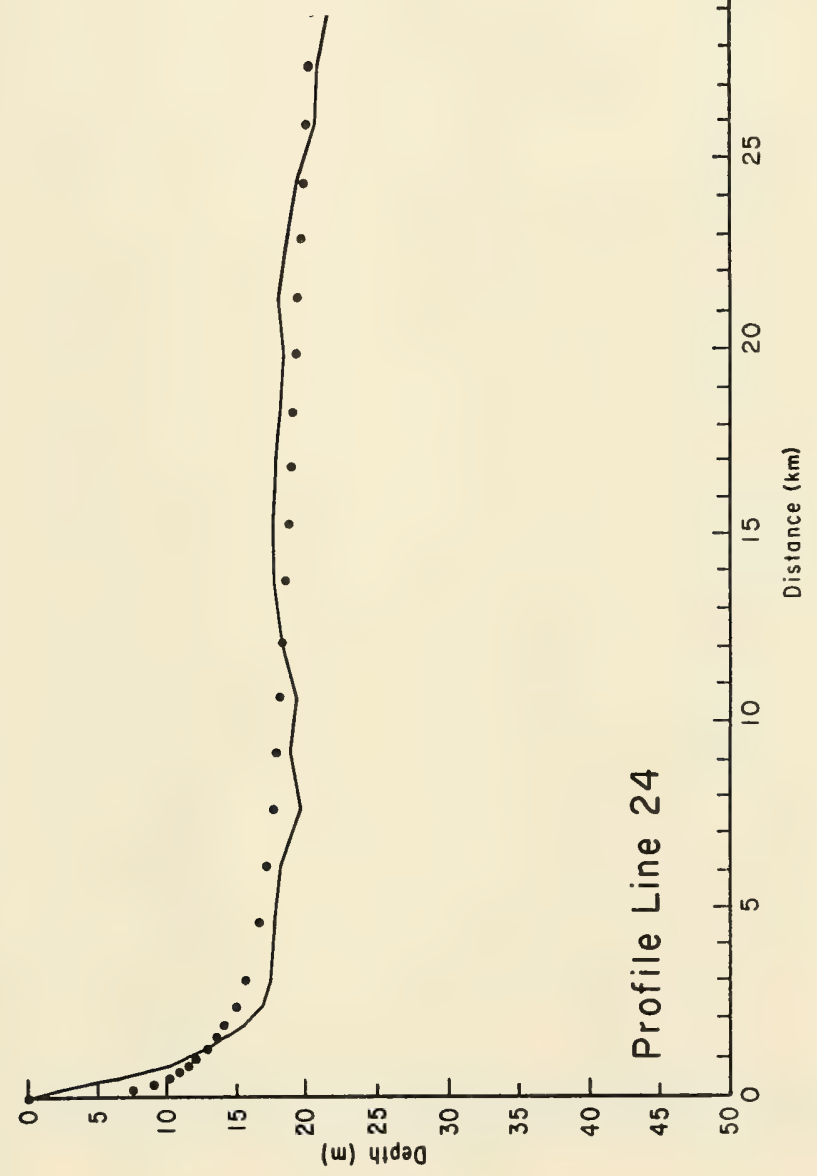




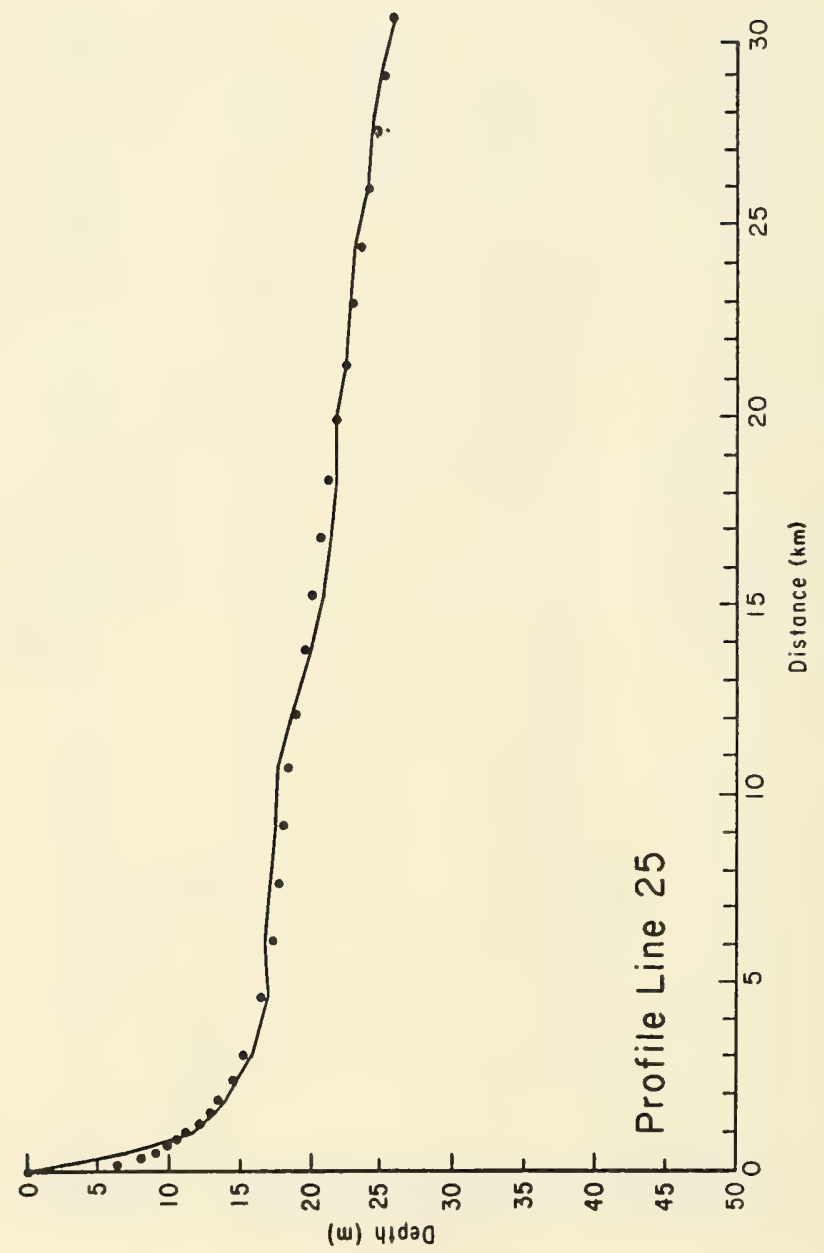




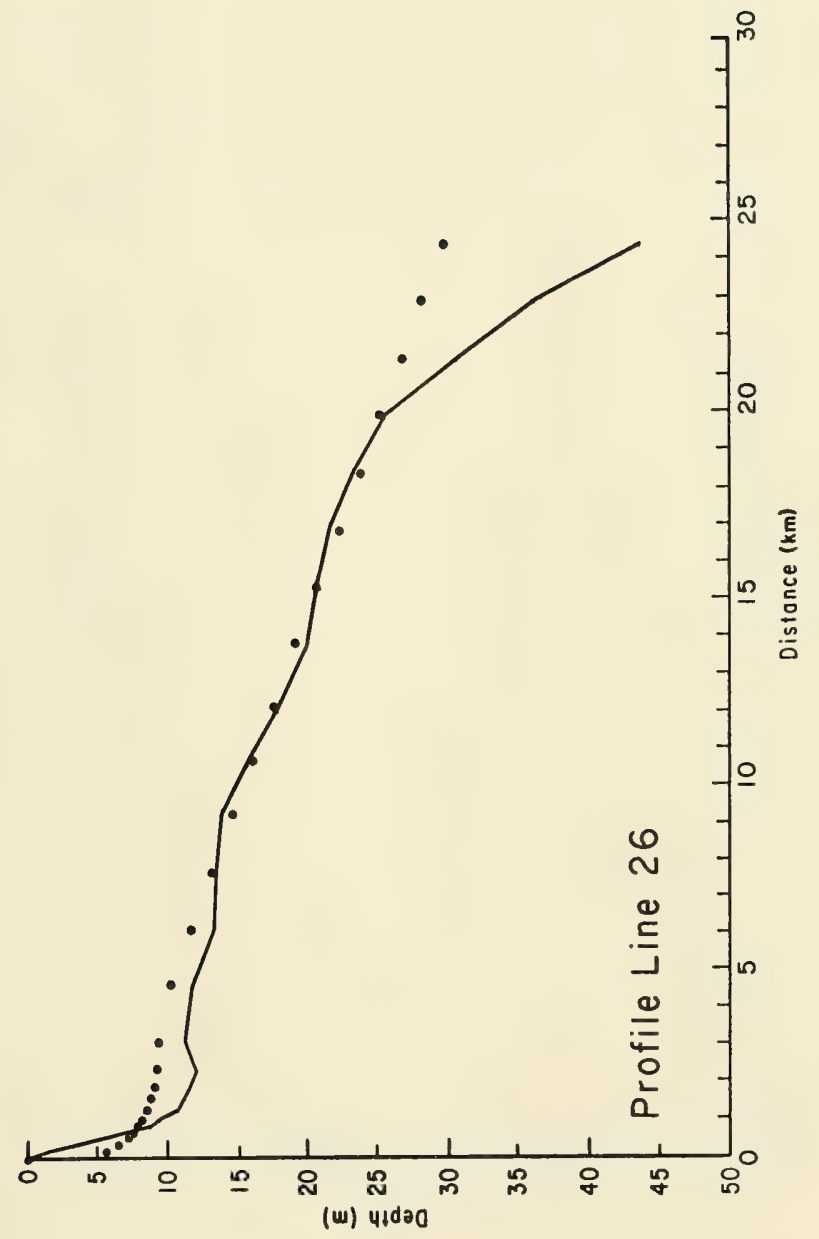




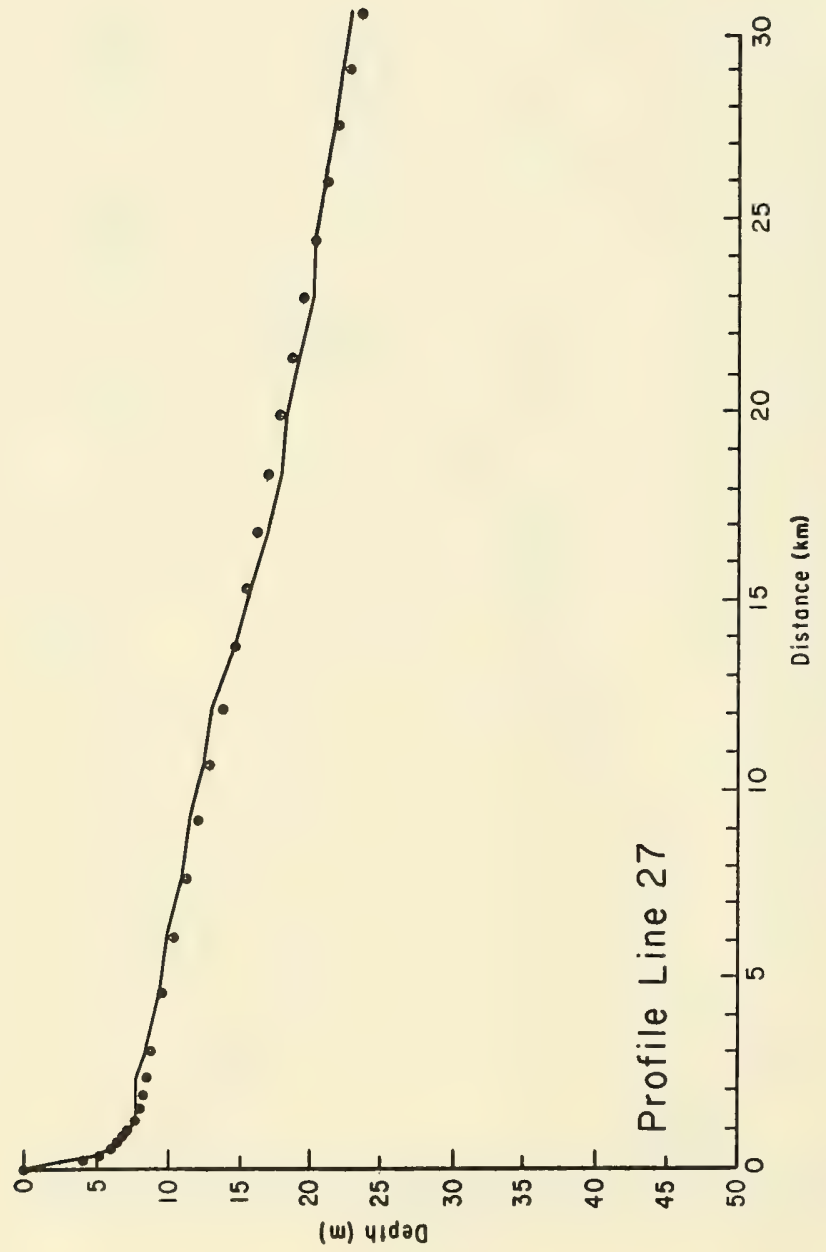




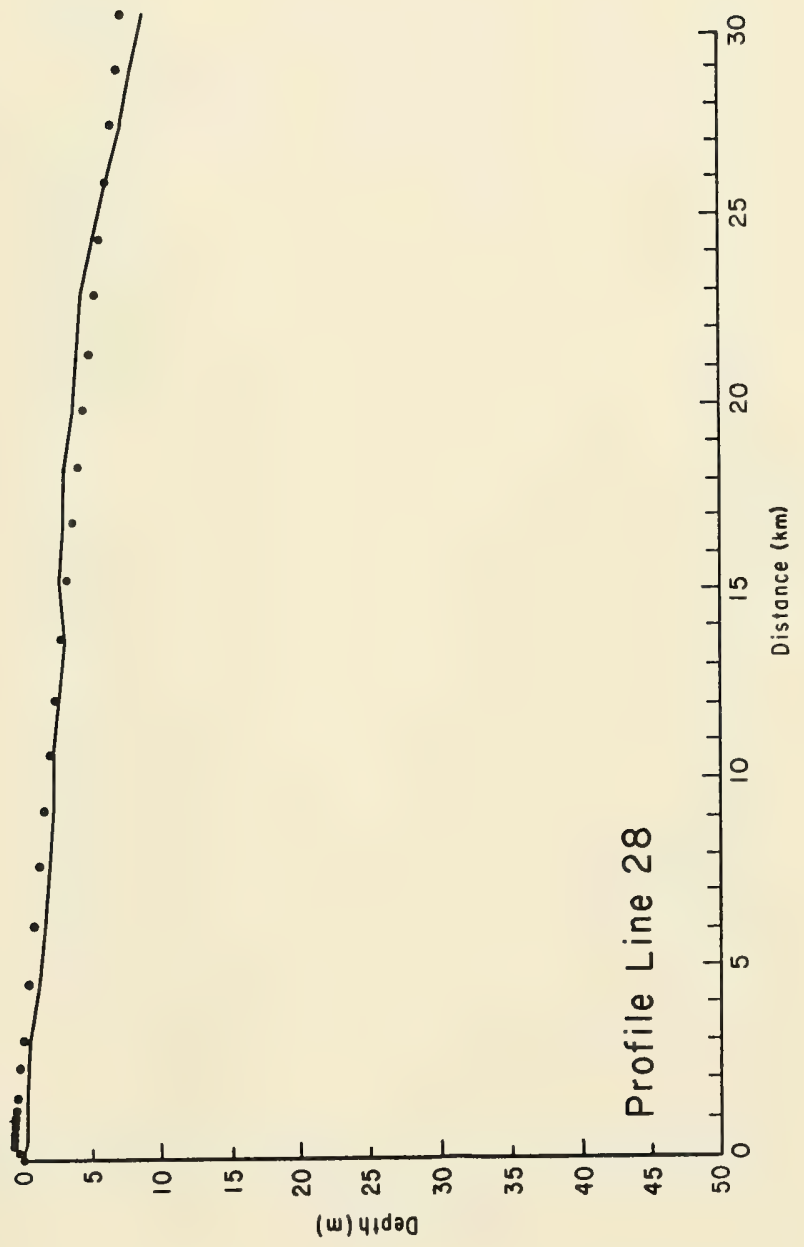




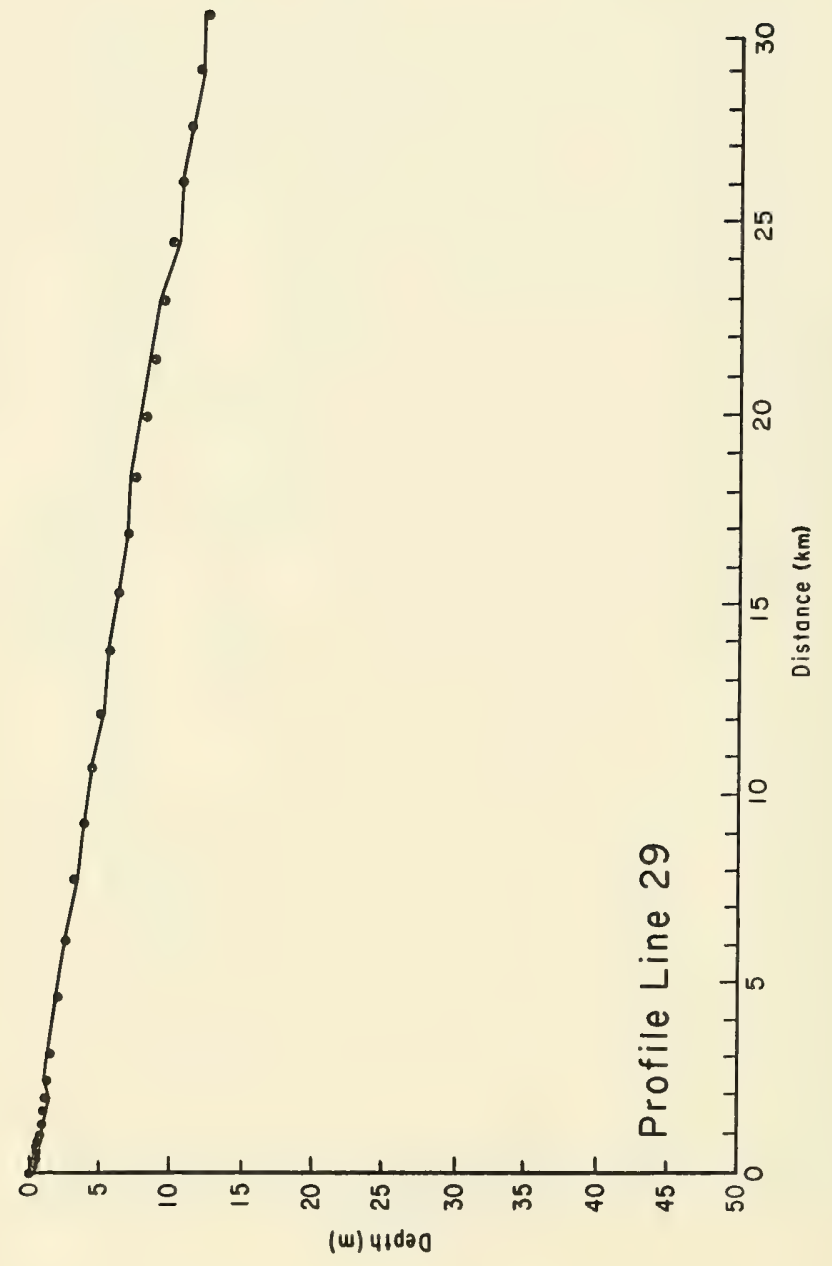




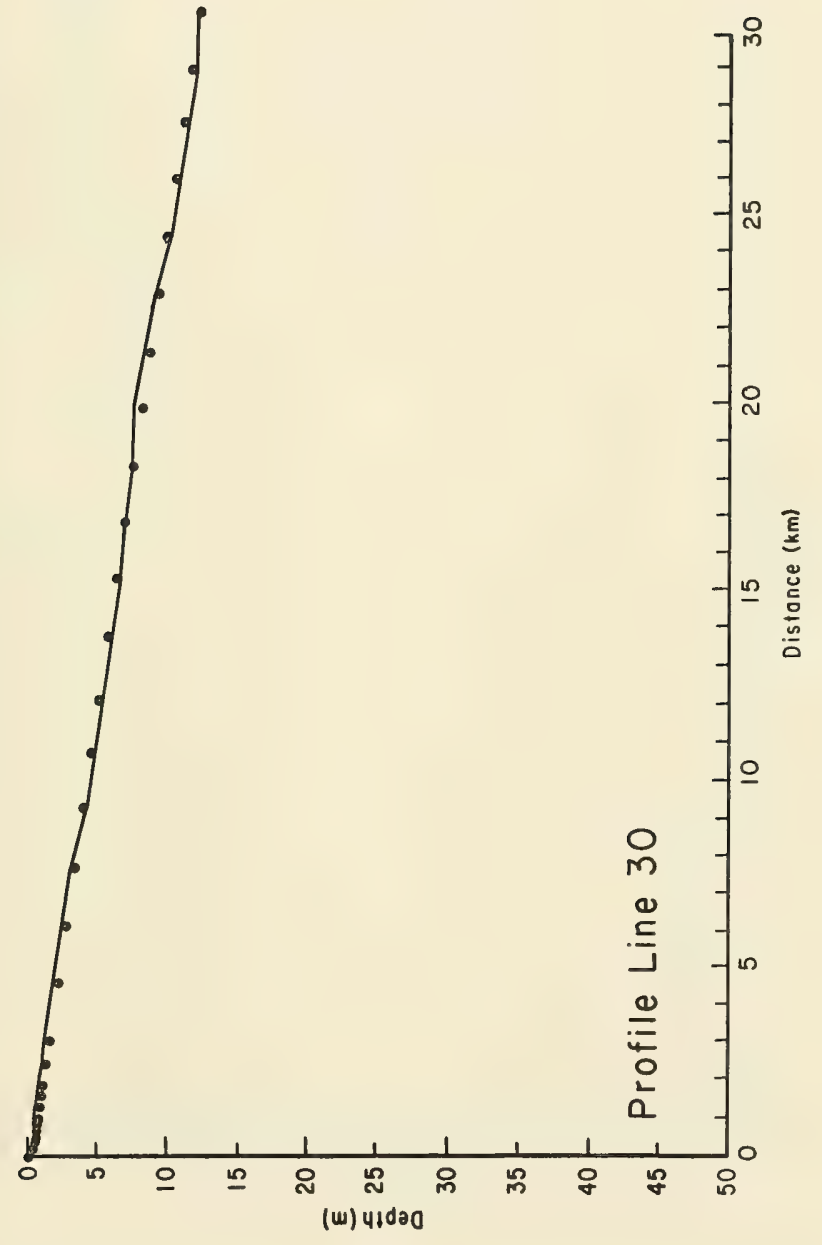




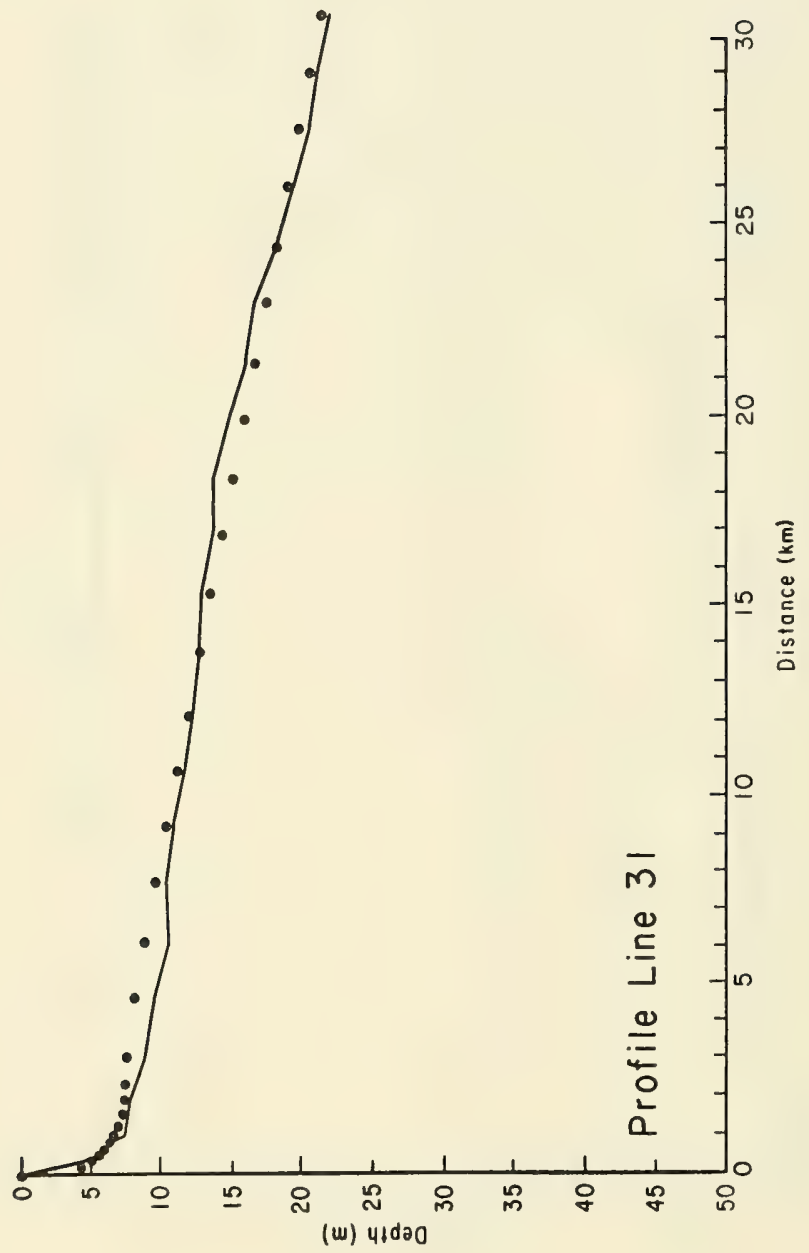




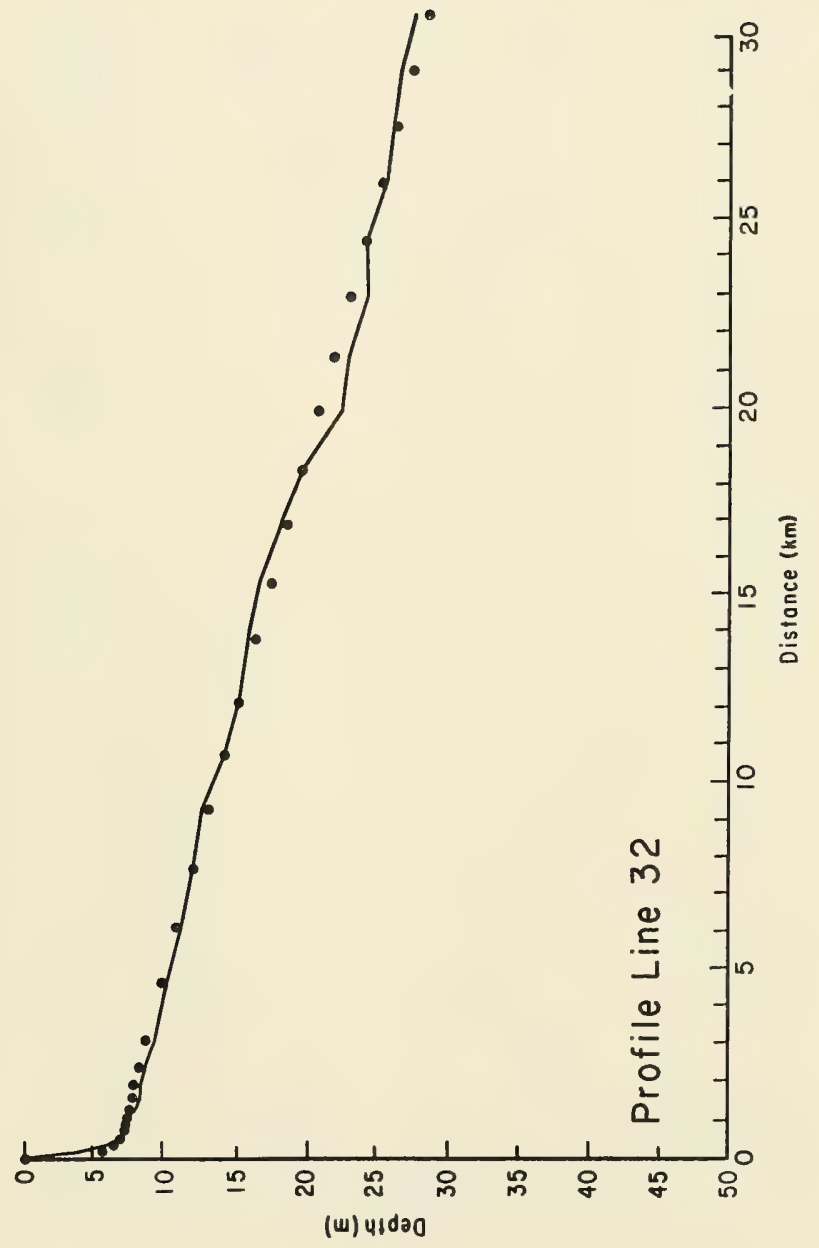




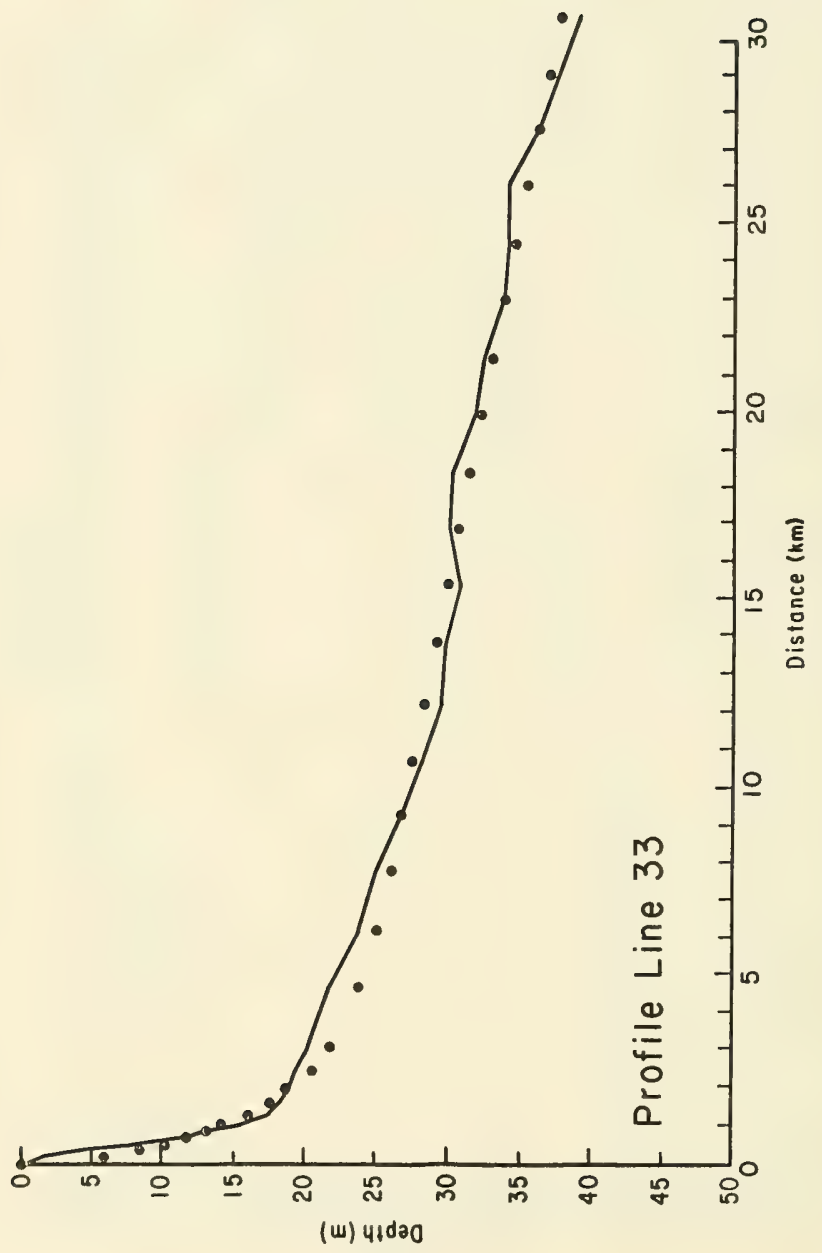




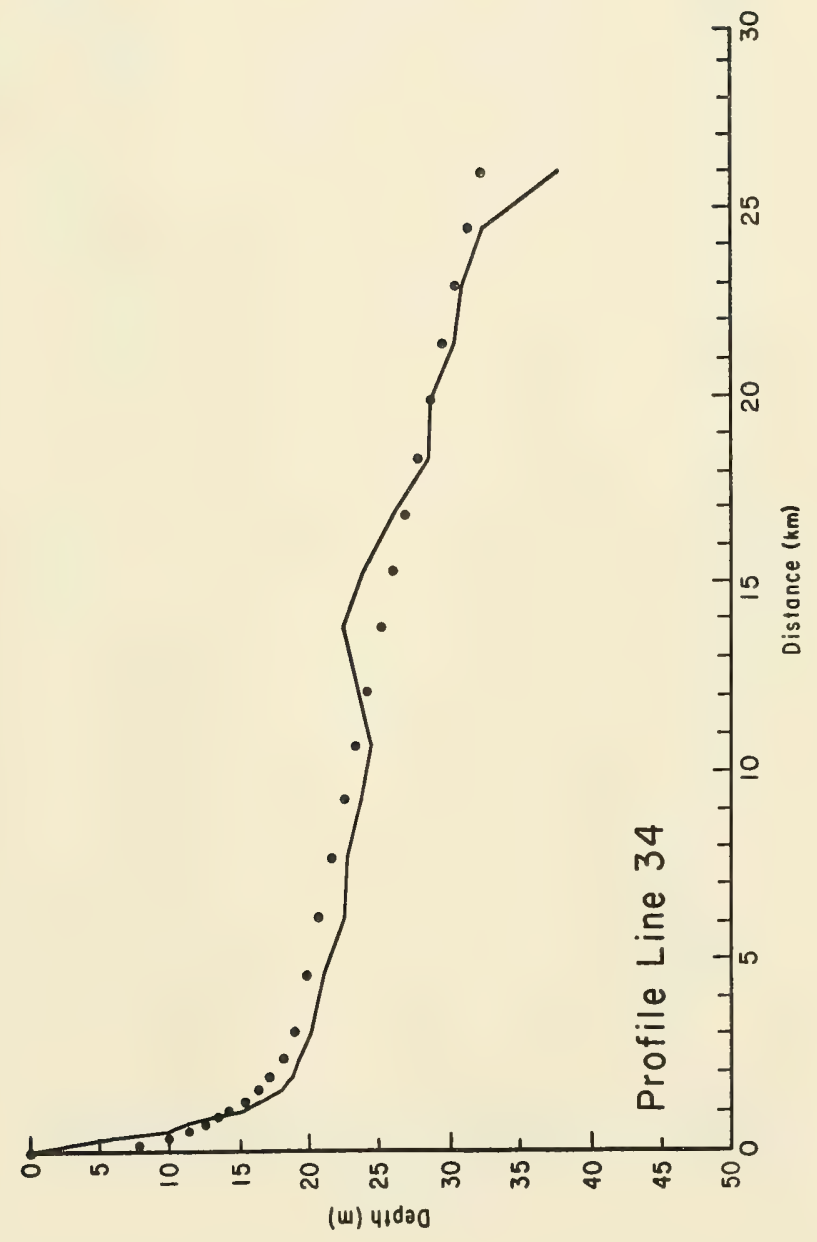




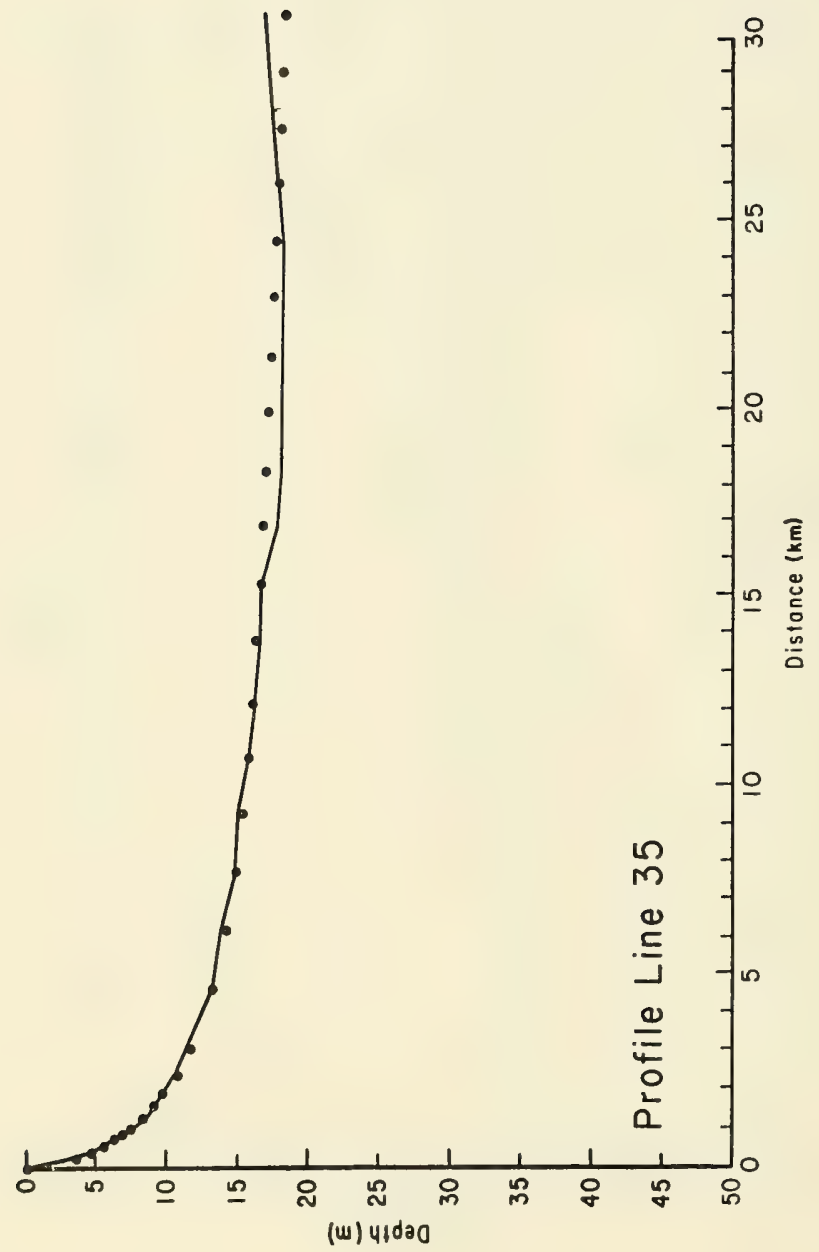




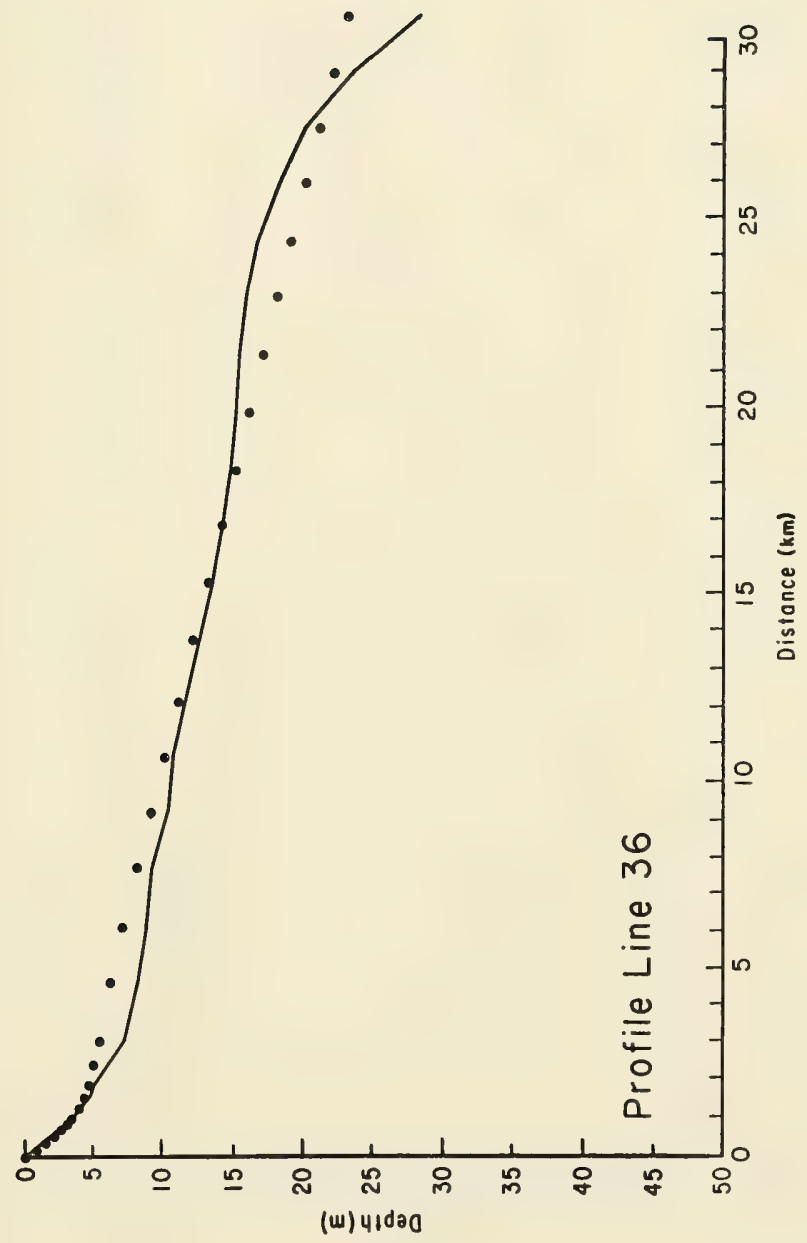




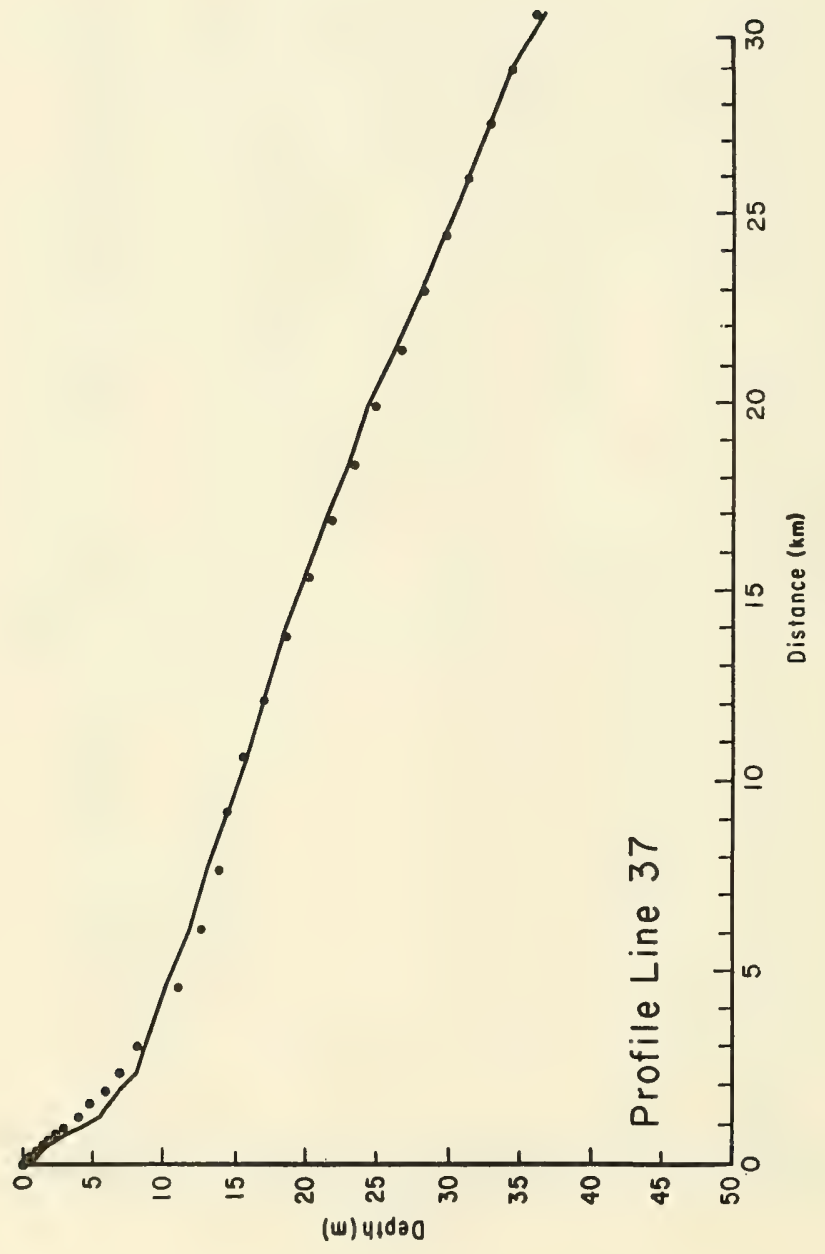




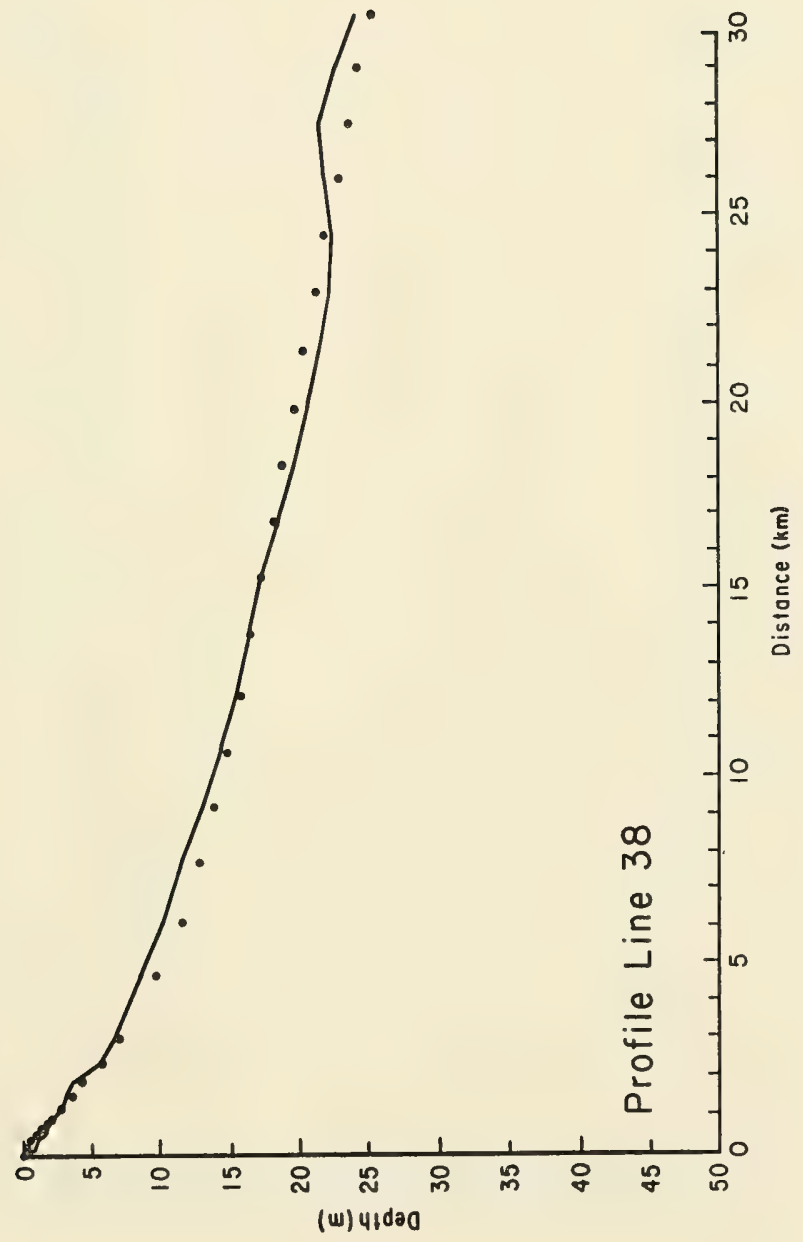




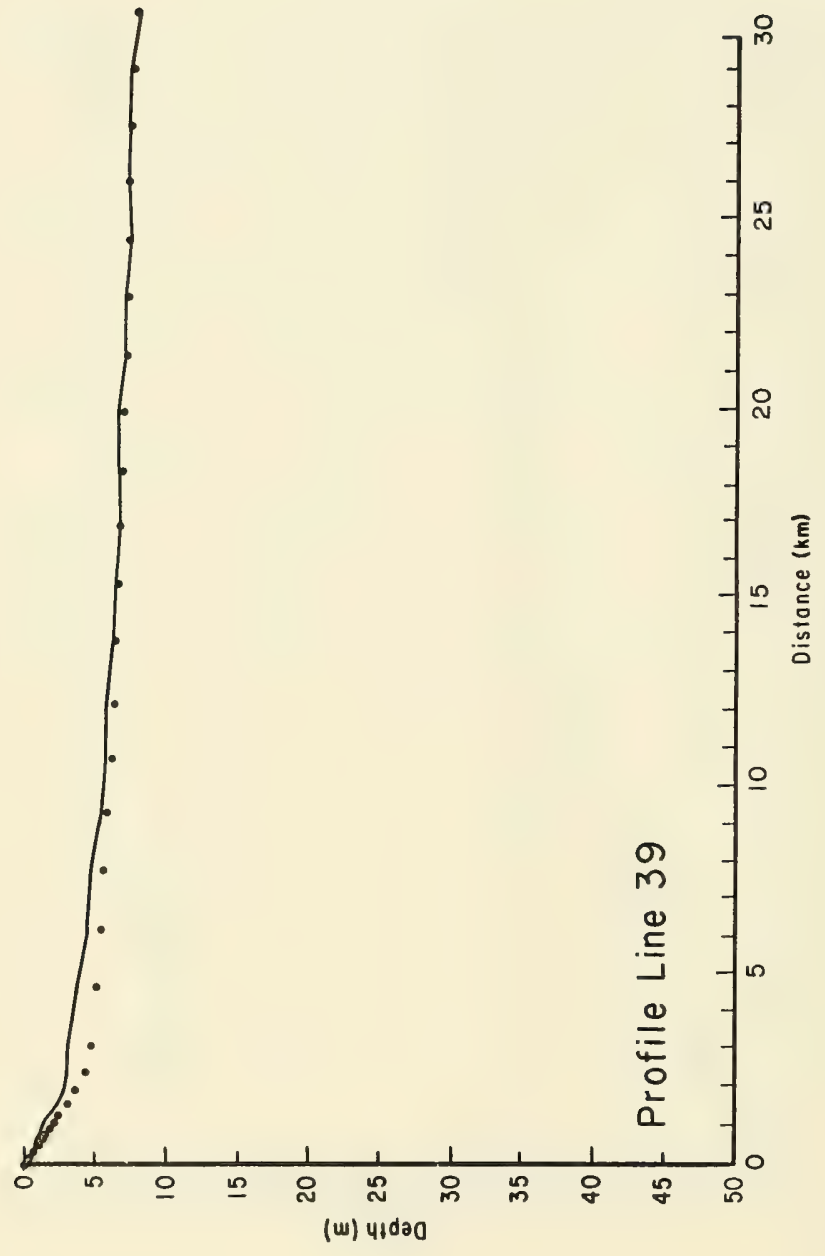




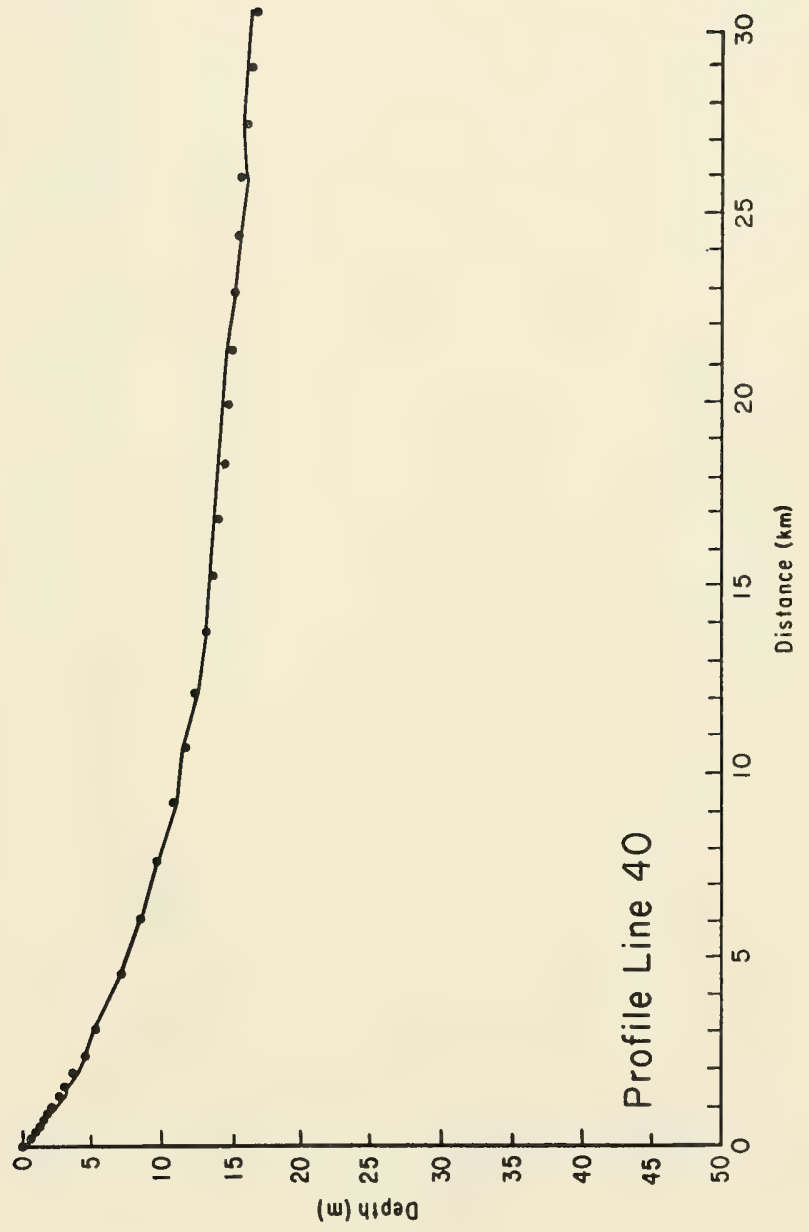




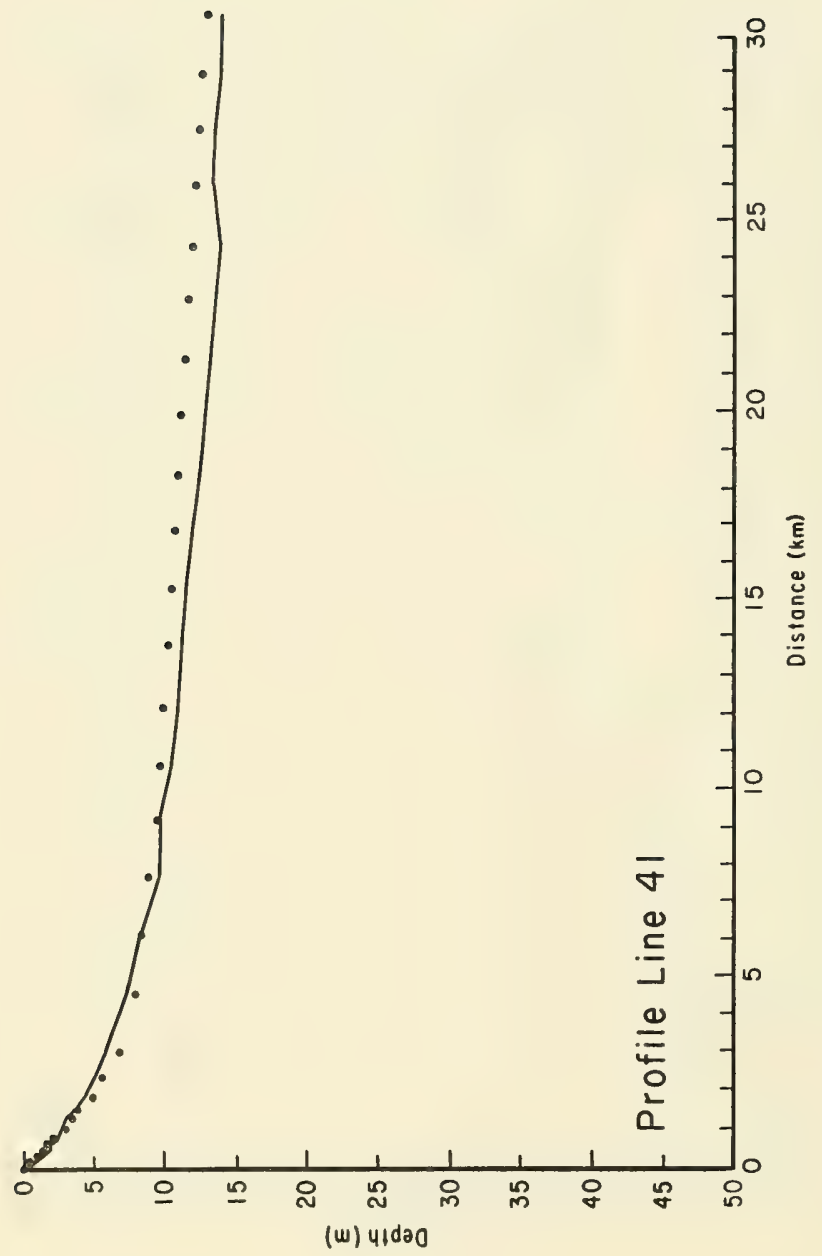




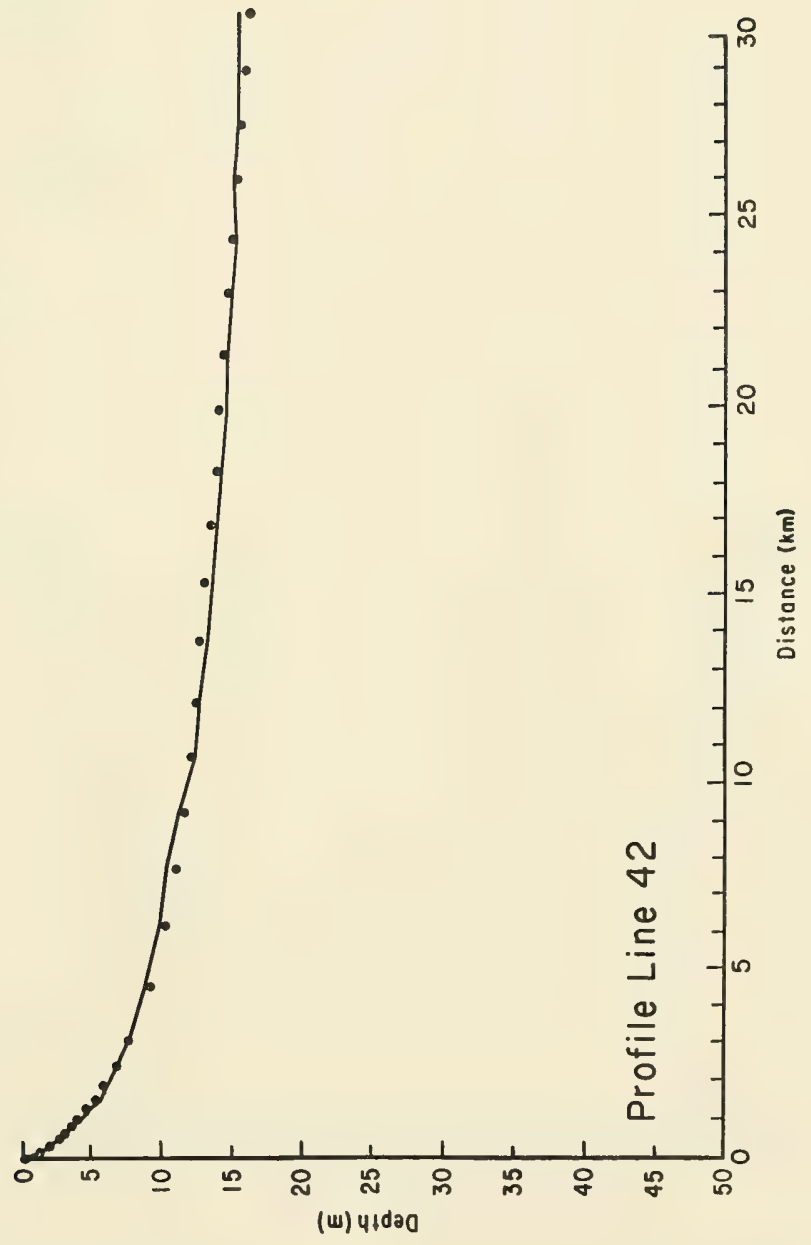




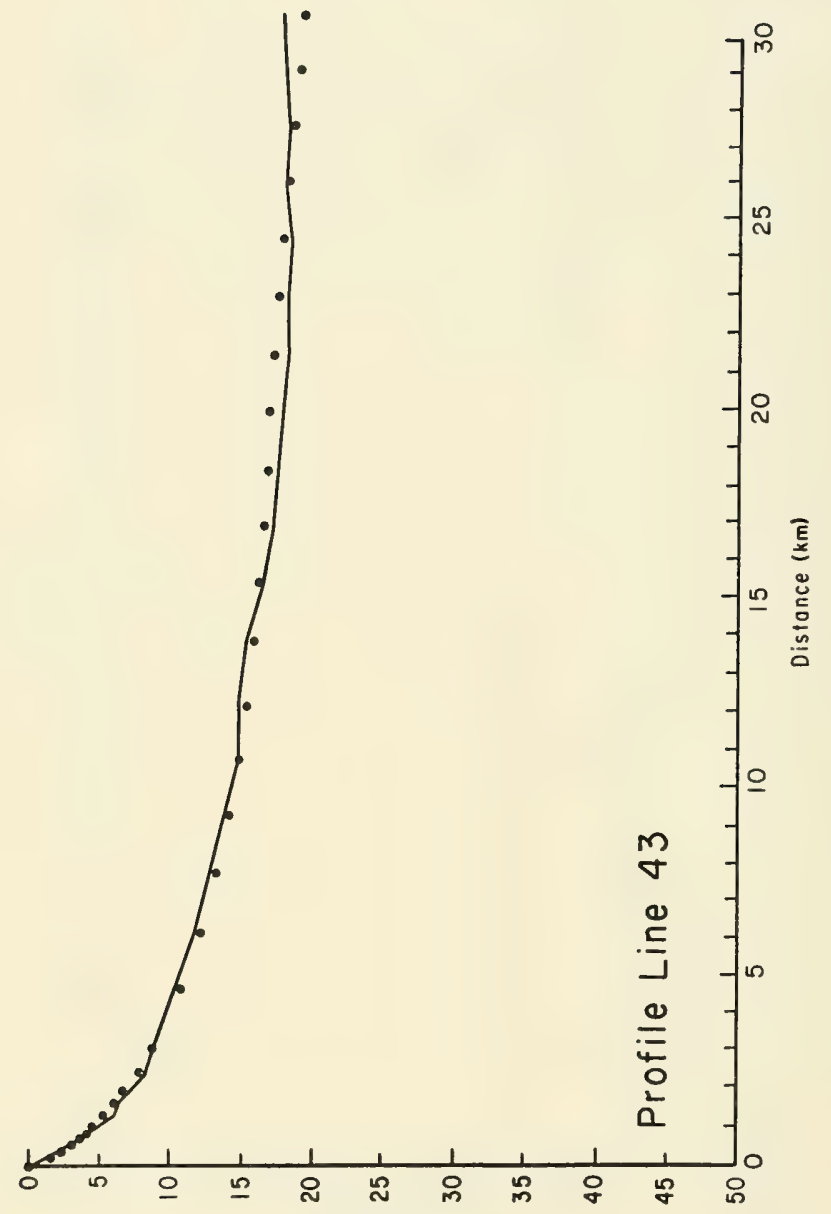

(w) प1d20 


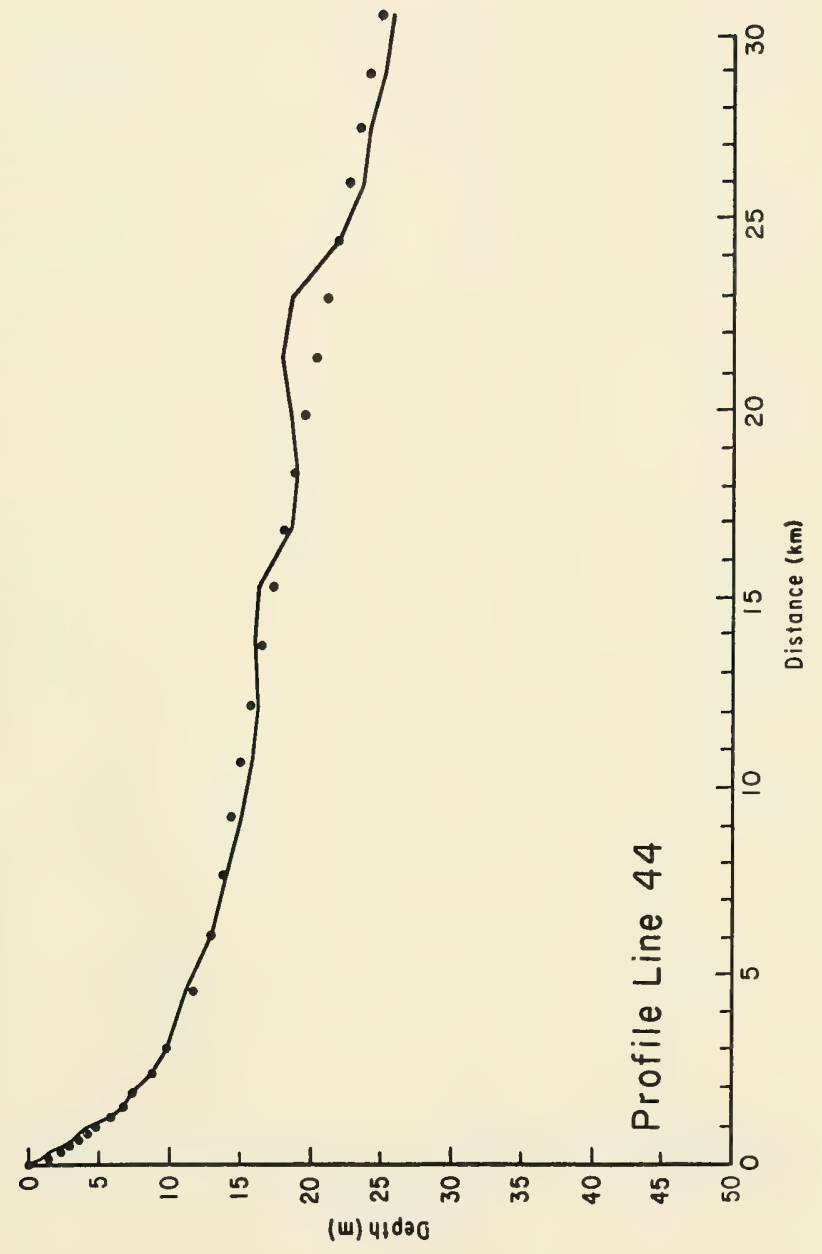




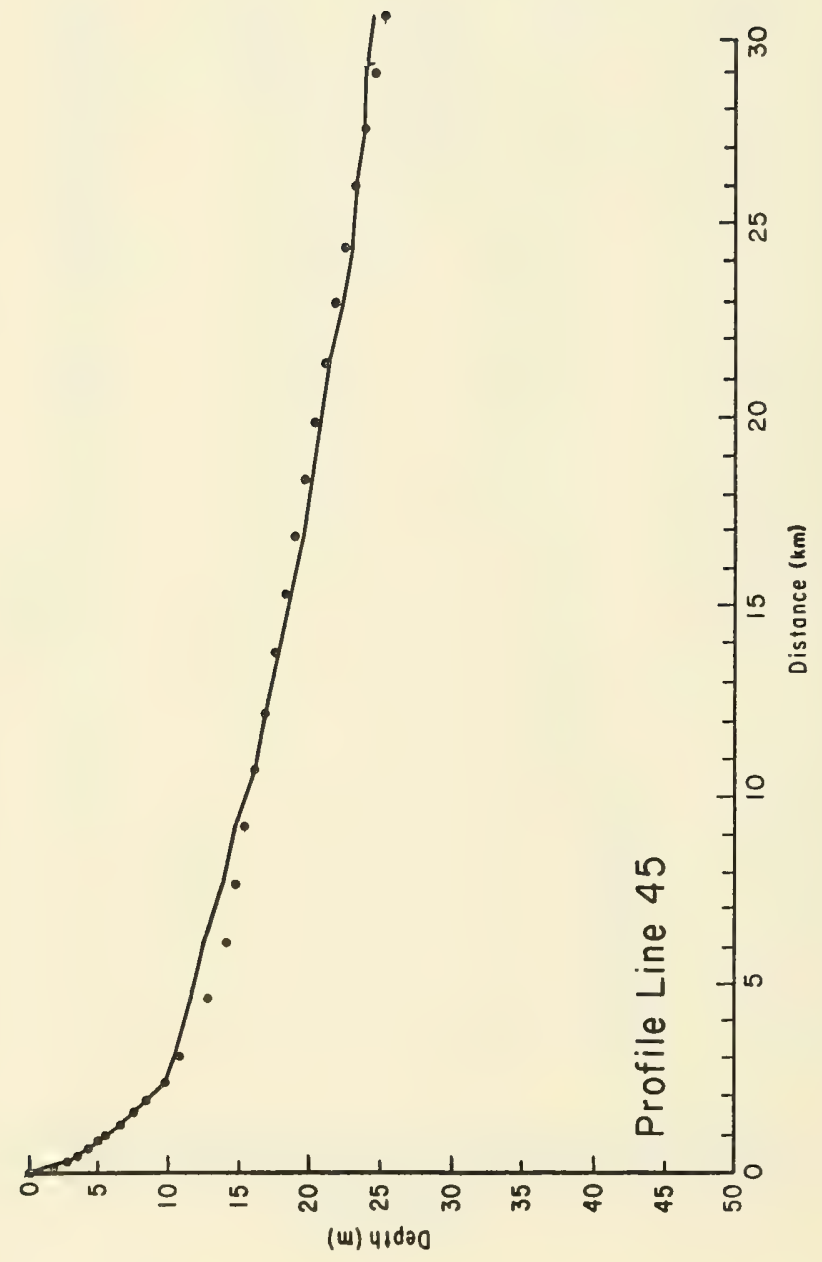




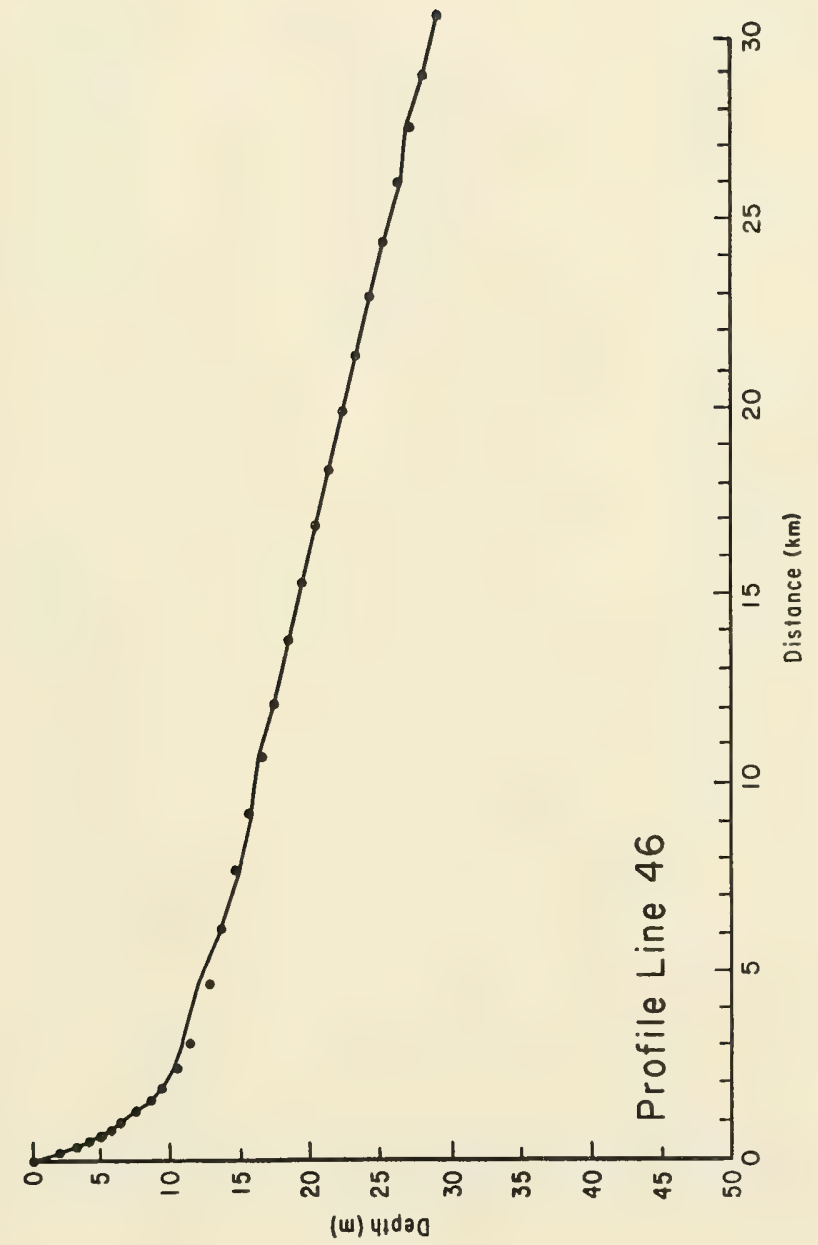




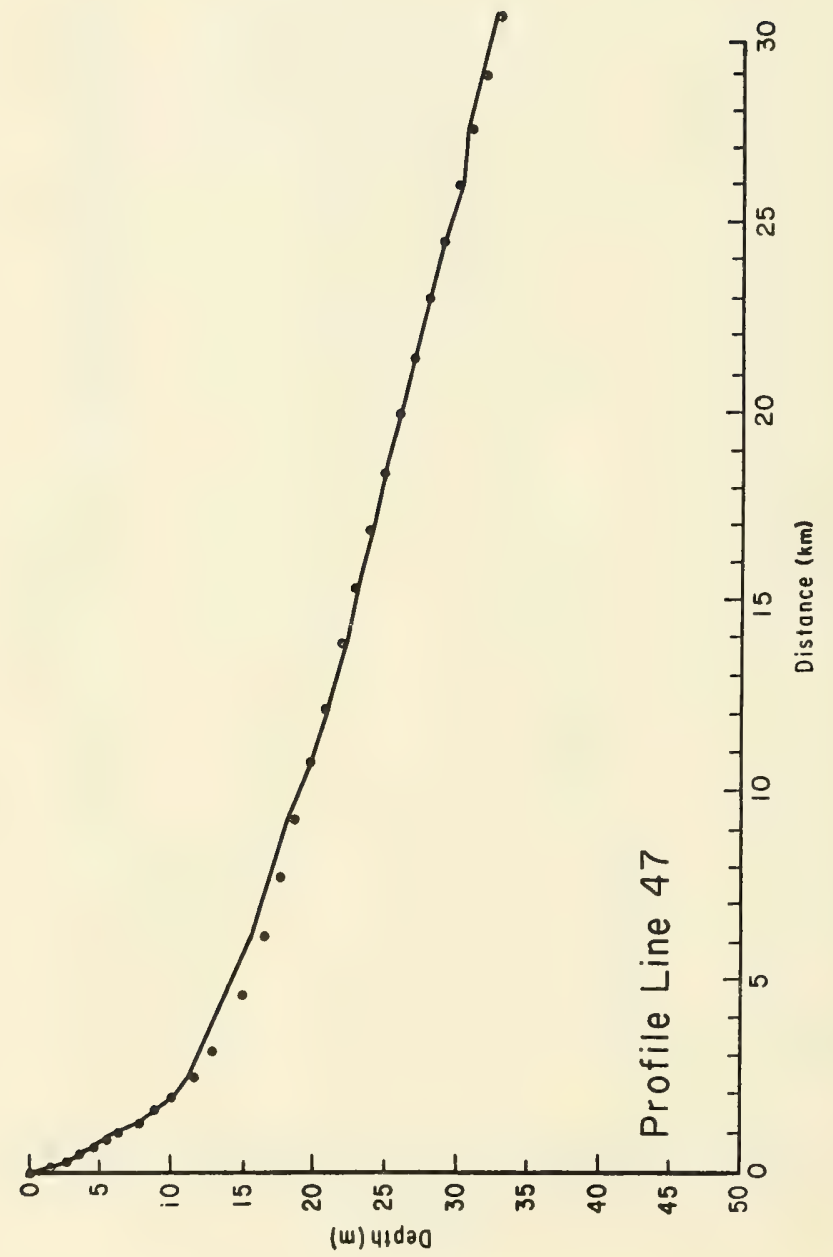




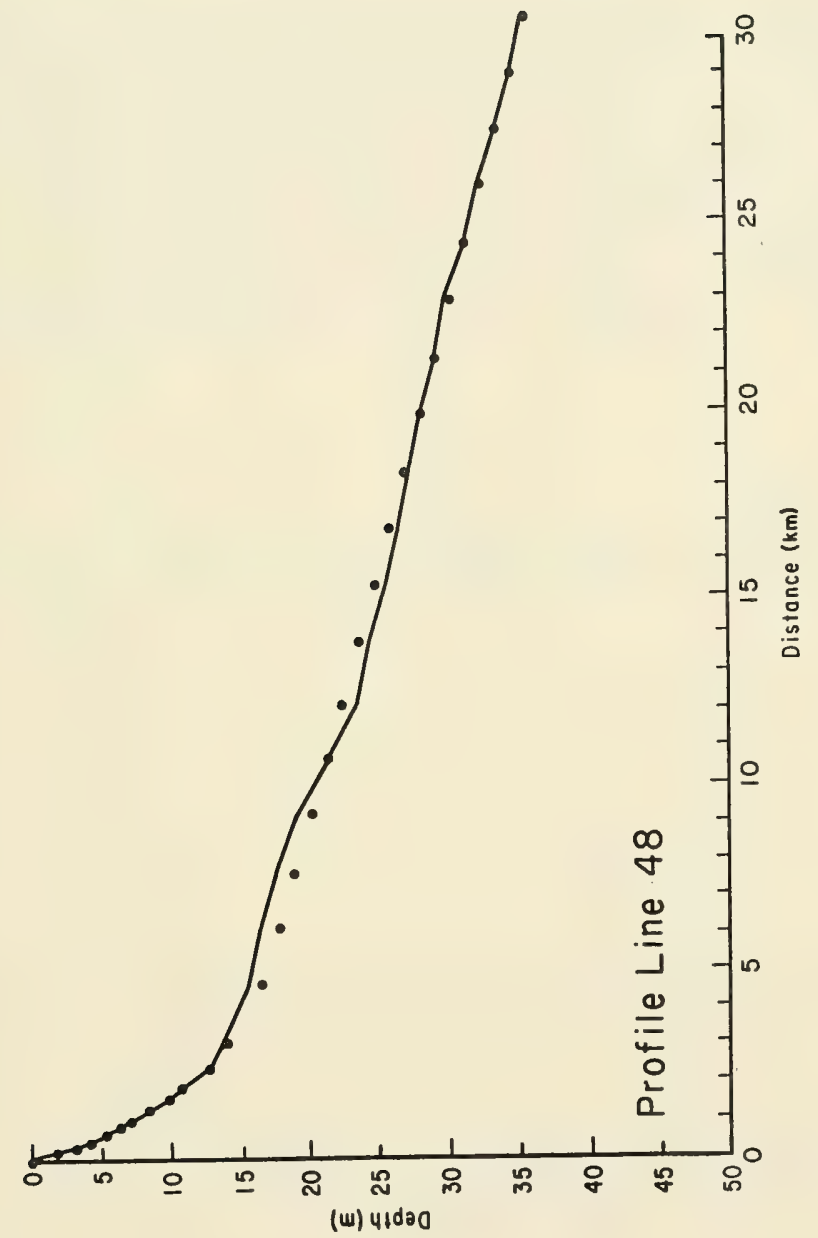




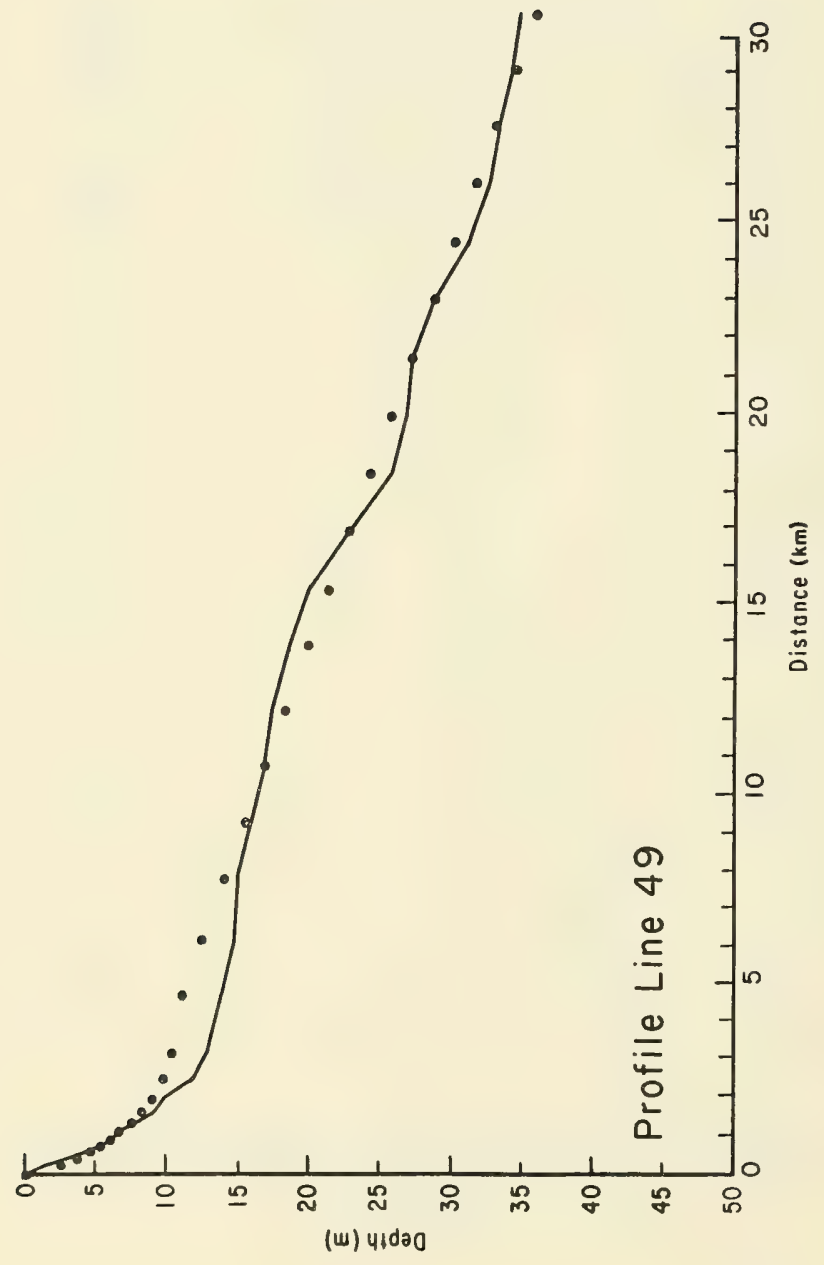




\section{PROFILE FITTING PROCEDURE}

This appendix discusses a procedure developed to mathematically fit a curve to a two-sector Inner Continental Shelf profile. In using the procedure, the values of four parameters obtained from a profile are required. These pararieters are based on empirically adjusted relationships among geometric characteristics of the profiles presented in Appendix C. The curve-fitting procedure is complex compared to other methods, primarily because of its ability to accommodate a wide variety of profile forms, and because the shoreface and ramp are considered separately. The ramp characteristics are determined, and the location of the shoreface-ramp boundary is specified. An empirical curve is fit to the shoreface sector and a term is used to combine the shoreface and ramp profiles. The result is a function of the form,

$$
z=z(x, a, b, c, d)
$$

in which $z$ is the bottom depth below MLW datum, $x$ is the distance from MLW shoreline, and a, b, c, d are shape parameters common to all 49 Inner Continental Shelf profiles (App. C).

\section{Ramp Term.}

The ramp depth, $z_{r}$, may be approximated by the equation of a straight line

$$
z_{r}=a x+b
$$

in which $a$ is the ramp slope; $b$ is the $z_{\Gamma}$ intercept at $x=0$, of the ramp extended to the coast (Fig. 5). The landward 1imit of the actual ramp, i.e., where the ramp meets the seaward boundary of the concave shoreface on the actual profile, did not appear to exceed 7.6 kilometers ( 4.7 miles) on any of the 49 profiles (App. C). Accordingly, the interval between 7.6 and 30.5 kilometers ( 4.7 and 19 miles) from shore was used for determining the ramp parameters, $a$ and $b$. It was not used in calculating the shoreface-ramp boundary coordinates $(\mathrm{g}, 3 \mathrm{c})$. The arbitrarily chosen outer ramp boundary was 30.5 kilometers, or as far seaward as the first of two or more slope segments between adjacent stations which exceed 0.003. Such an atypical situation exists, for example, when the Continental Shelf is less than 30.5 kilometers wide off eastern Florida. The calculated $a$ and $b$ values as well as the correlation coefficient for each ramp profile as obtained using a least squares method for determining the line that best fit the ramp data were listed in Table 1. In most cases 12 or more points were used to define the correlation coefficient for the ramp segment (Table 1, App. C). 


\section{Shoreface-Ramp Boundary.}

Irregularities common in the lower part of the shoreface (Fig. 4) limit its use in determining where the ramp and shoreface merge. The landward limit of shoreface irregularities was near the first station with a slope less than three times the mean ramp slope, a, or less than 0.0006 . Consequently, this was arbitrarily selected as the definition of the boundary between the lower and upper shoreface. Use of the 0.0006 value is necessary because 12 percent of the offshore gradients were less than 0.0002 (Table 1), and exclusive use of the ramp slope criterion would result, at times, in defining the upper shoreface within an irregular region. The distance, c, from the shoreline to the upper and lower shoreface boundary is as shown in Figure 5.

The shoreface and ramp intersect asymptotically making the location of the coupling difficult to determine. The distance $3 \mathrm{c}$ approximated the location such that the calculated ramp depth was within 3 percent of the actual depth.

\section{Shoreface Term.}

The shoreface slope, steepest near the shoreline, usually exhibited maximum concavity near the ramp (Fig. 5). The shoreface shape may be approximated by an exponential curve of the form,

$$
\frac{\mathrm{d} \mathrm{z}_{s}}{\mathrm{dx}}=-\mathrm{k}_{1} \mathrm{z}_{s}
$$

in which $k_{1}$ is the constant, and $z_{s}$ is the depth to the shoreface profile. An exponential fitting method was selected because wave energy available at the bottom, which partially molds the profile shape, decreases exponentially with depth. Equation (D-3) integrates to

$$
1 n z_{s}=-k_{1} x+1 n k_{2}
$$

with

$$
z_{S}=k_{2} \exp ^{-k_{1}} x
$$

and where $k_{1}$ and $k_{2}$ are constants. The following boundary conditions are necessary to fit the constants to the shoreface profile: $z=0$, at $x=0$, and $z=a x+b$ at $x=3 c$. If the depth at the shoreface-ramp boundary (Fig. 5), g, 


$$
g=3 a c+b
$$

is assigned as the multiplicand of $1-\exp ^{-k_{1} x}$, the boundary conditions are satisfied and the shoreface function becomes

$$
z_{s}=g\left(1-\exp ^{-k_{1} x}\right)
$$

To fit a curve to the shoreface of the 49 profiles, and to evaluate the characteristics of $-k_{1} x$, the inshore sector, 300 meters ( 1,000 feet) $<\mathrm{x}<\mathrm{c}$, was used because it was relatively smooth. The shoreface profile in the nearshore region, $x<300$ meters, was not considered because it is relatively unsteady and is frequently complicated by offshore bars. Because of shape irregularities, the region between $c$ and $3 c$ is not particularly useful in evaluating the goodness of fit of a mathematically generated curve to the actual shoreface profile. Since it is desirable that $c$, a boundary parameter, be used, and because the landward profile between $x=300$ meters and $x=c$ is evaluated, the function may be rewritten as

$$
z_{S}=g\left(1-\exp \frac{-x}{c}\right)^{f}
$$

in which $f$ is the exponent defining concavity. Using a computer, values of $f$ from 0.01 to 5.00 were evaluated by trial-and-error comparisons of the actual upper shoreface profile (App. C) and the computed (eq. D-8) upper shoreface profile. The $f$ value was assigned corresponding to the smallest residual value $R$ (in square meters) where

$$
\mathrm{R}=\sum_{\mathrm{i}}^{\mathrm{p}} \frac{\left(z_{i}-z_{i}\right)^{2} \frac{\left(x_{i+1}-x_{i-1}\right)}{2}}{200}
$$

in which $z_{i}$ is the calculated depth at $x_{i}$ using an $f$ value, and $\mathrm{z}_{i}$ is the actual depth value at $\mathrm{x}_{i} ; \mathrm{p}$ is the number of distance stations between $\mathrm{x}=300$ meters and $\mathrm{x}=\mathrm{c}$. The $\mathrm{x}_{i}$ values reference distance from shore. $\mathrm{R}$ is, therefore, a distance-weighted scale which references the mean variation of the elevation interval squared between the actual upper shoreface depth and the value calculated according to equation (D-8). The values of $f$ for the 49 profiles are listed in Table 1. The $f$ value chosen varies inversely with the concavity index, I, defined as

$$
I=\frac{d / c}{g / 3 c}
$$


in which $d$ is the profile depth at $c$, and $g$ is the depth at $3 c$. Figure D-1 is a semilogarithmic plot of $f$ versus $I$.

\section{Combination Term.}

A combining function is necessary to define the influence of the ramp and shoreface profiles (eqs. D-1 and D-8) as they asymptotically merge. An analysis of various smooth-type shoreface profiles, such as profile line 15 in Figure 4, indicates that approximately 88 percent of the change from the shoreface to the ramp sector shape occurs between $\mathrm{x}=2 \mathrm{c}$ and $\mathrm{x}=3 \mathrm{c}$; i.e., about 88 percent of the shape of the actua 1 profile in that region can be described using equation (D-8). The term that approximates the influence of both the shoreface and the ramp in that region is

$$
G=\exp ^{-2.8}\left(\frac{x}{3 c}\right)^{10}
$$

in which the constant 2.8 ensures that less than 6 percent of the profile at $x=3 c$ is influenced by the shoreface sector, and that less than 6 percent of the profile at $x=2 c$ is influenced by the ramp sector. The value $3 c$ is considered to be the seaward limit of the shoreface.

5. Inner Continental Shelf Profile Equation.

Four constants: $a=$ ramp slope, $b=$ ramp intercept depth at the shoreline, $c=$ seaward limit of upper shoreface, and $d=$ depth at $c$, are combined in the equation for the Inner Continental. Shelf profile:

$$
z=(1-G)(a x+b)+G\left[g\left(1-\exp \frac{-\frac{x}{c} f}{f}\right]\right.
$$

Points on the profiles in Figure 4 and Appendix $\mathrm{C}$ are depth-distance points obtained using equation (D-12). An APL computer program of equation $(\mathrm{D}-12)$ is in Appendix E. 


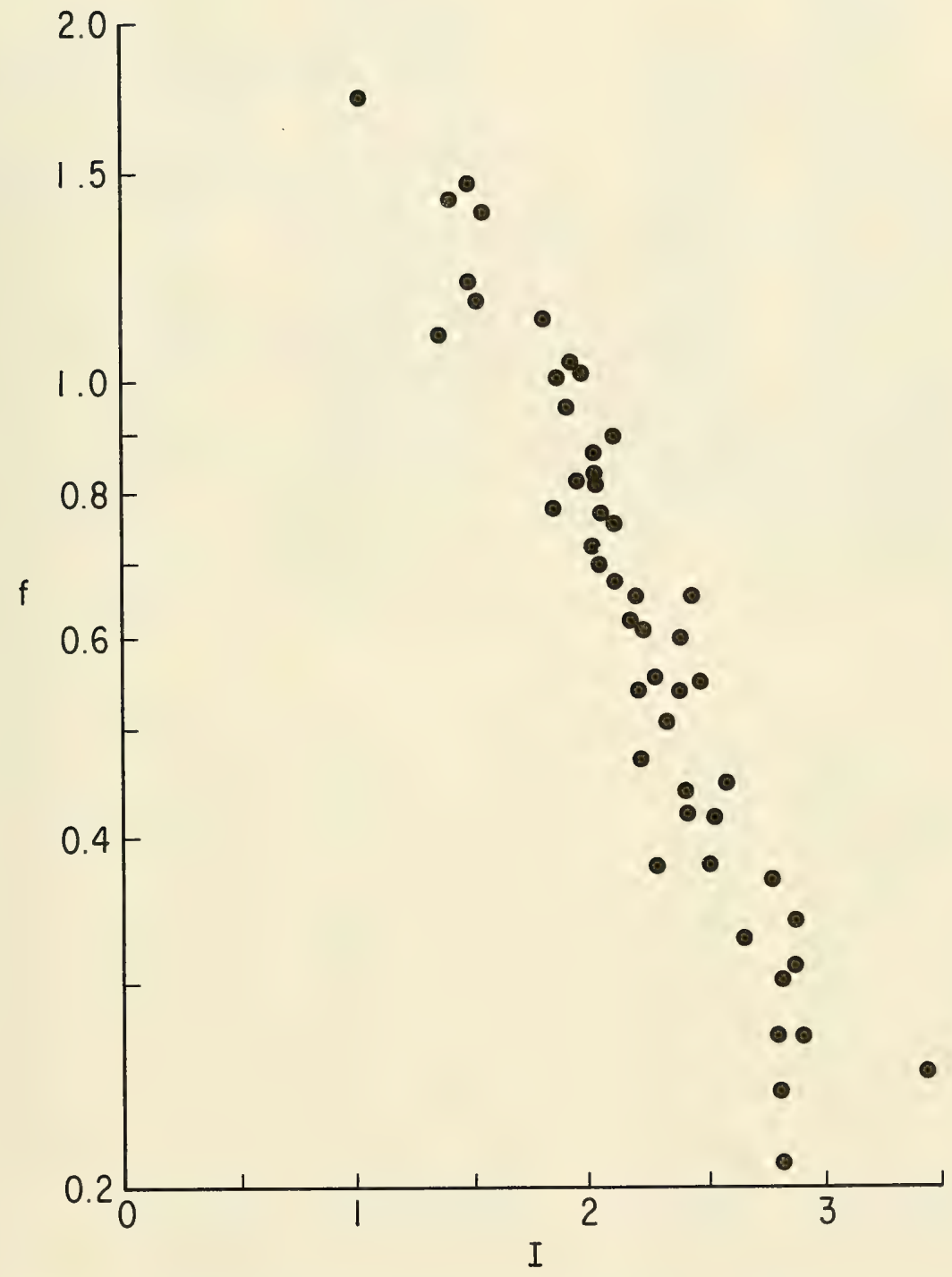

Figure D-1. Semilogarithmic plot of $f$ versus $I$, where $I=3 d / g$ (see Fig. 5). An approximation of the plotted values is $f=2.8(1-d / g)$ with a correlation coefficient of -0.94 . 


\section{APPENDIX E}

A PROGRAMING LANGUAGE (APL) PROGRAM TO FIT A CURVE TO A PROFILE

$\nabla R \leftarrow$ SIILL X; $E ; G$

[1] A SHLI, IS A FUIVCIOIJ TO DESCRIBE AIV INWER-CONTINENTAL

[2] $ค$ SHELF PROFJIIE

[3] a PROGRAMMER: C RVERTS, 3 TUIIR 1376

[4] a THT RLOUIRED COISTAII VALUES ARE:

[5] 9 A $=$ IIALP SLOPL

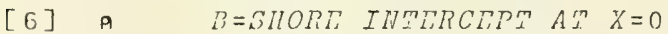

[7] A G CDISHAHCF TO UPPER/IOUER SHOREFACE BOUIVARY

[3] ค (3C=SHORERACE/RAMP BOUMDARY $)$

[9] a F=CONCAVITY PARAMETER

[10] ค $X=D I S M A I C E$ PROI SIIORELIIJE

[11] a AHY UHITS, APPLIED COHSISTAITIY, MAY BE USED

[12] $G * 2.731 *(-2.8 \times((X \div(3 \times C)) * 10))$

[13] $\quad F+(A \times C \times 3)+B$

[14] $R *((1-G) \times((A \times X)+B))+(G \times(T \times((1-(2.781 *(-(X \div C)))) * F)))$ $\nabla$ 


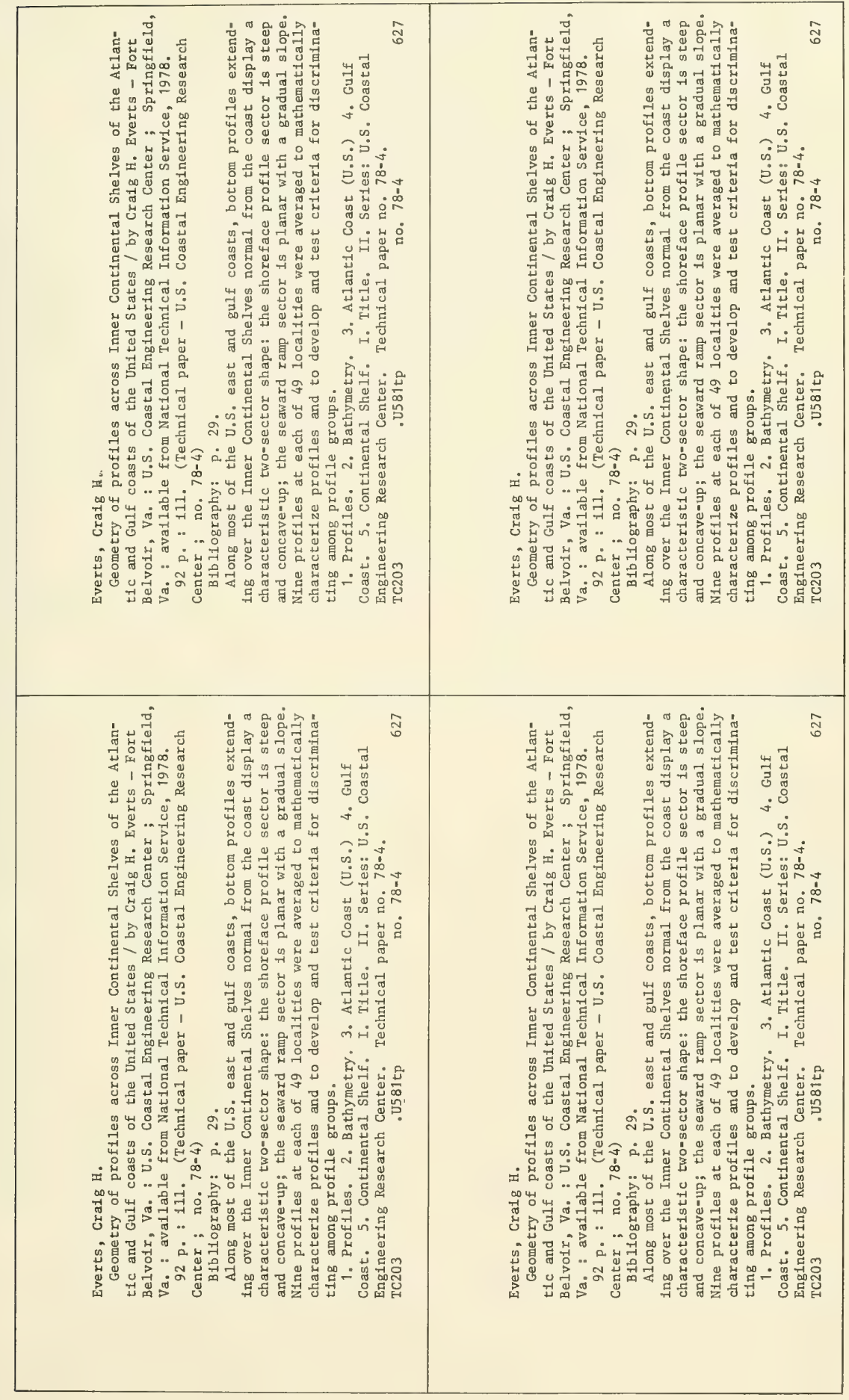





\begin{tabular}{|c|c|}
\hline 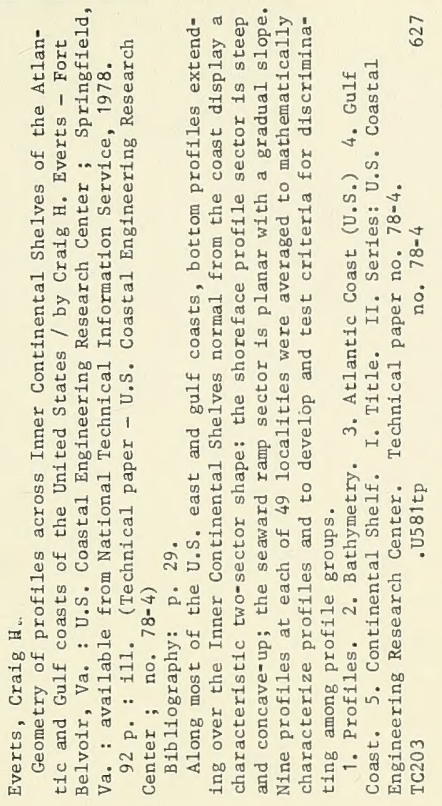 & 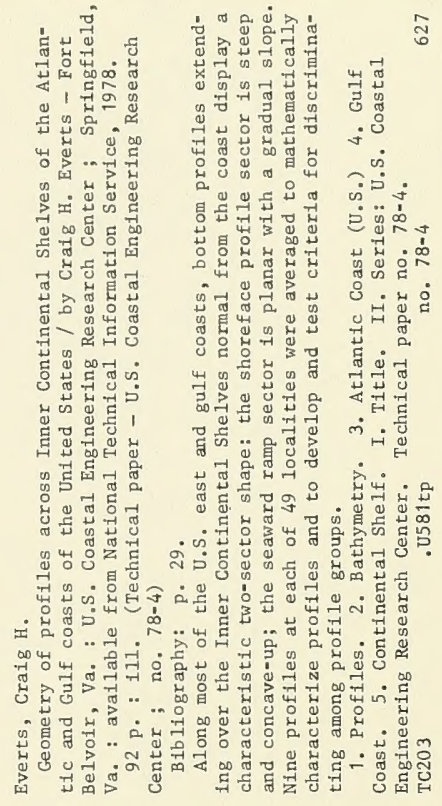 \\
\hline 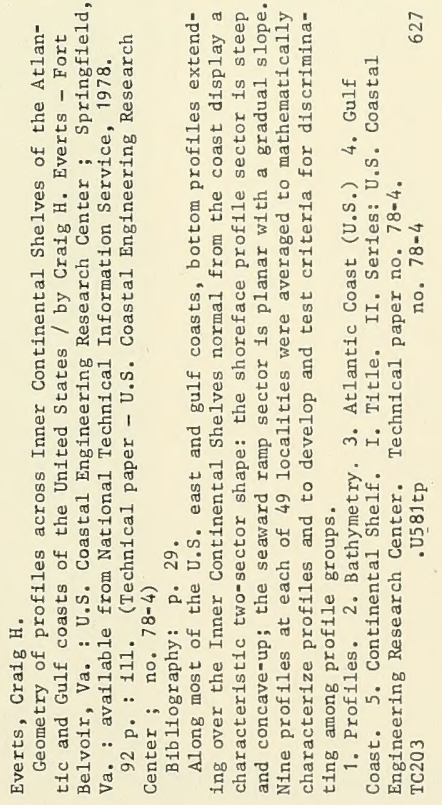 & 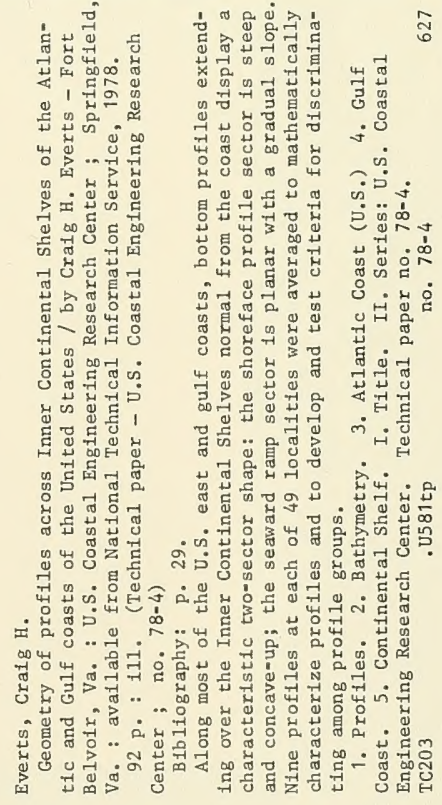 \\
\hline
\end{tabular}




